\title{
Olhares da mídia na Amazônia: movimentos e manifestações
}

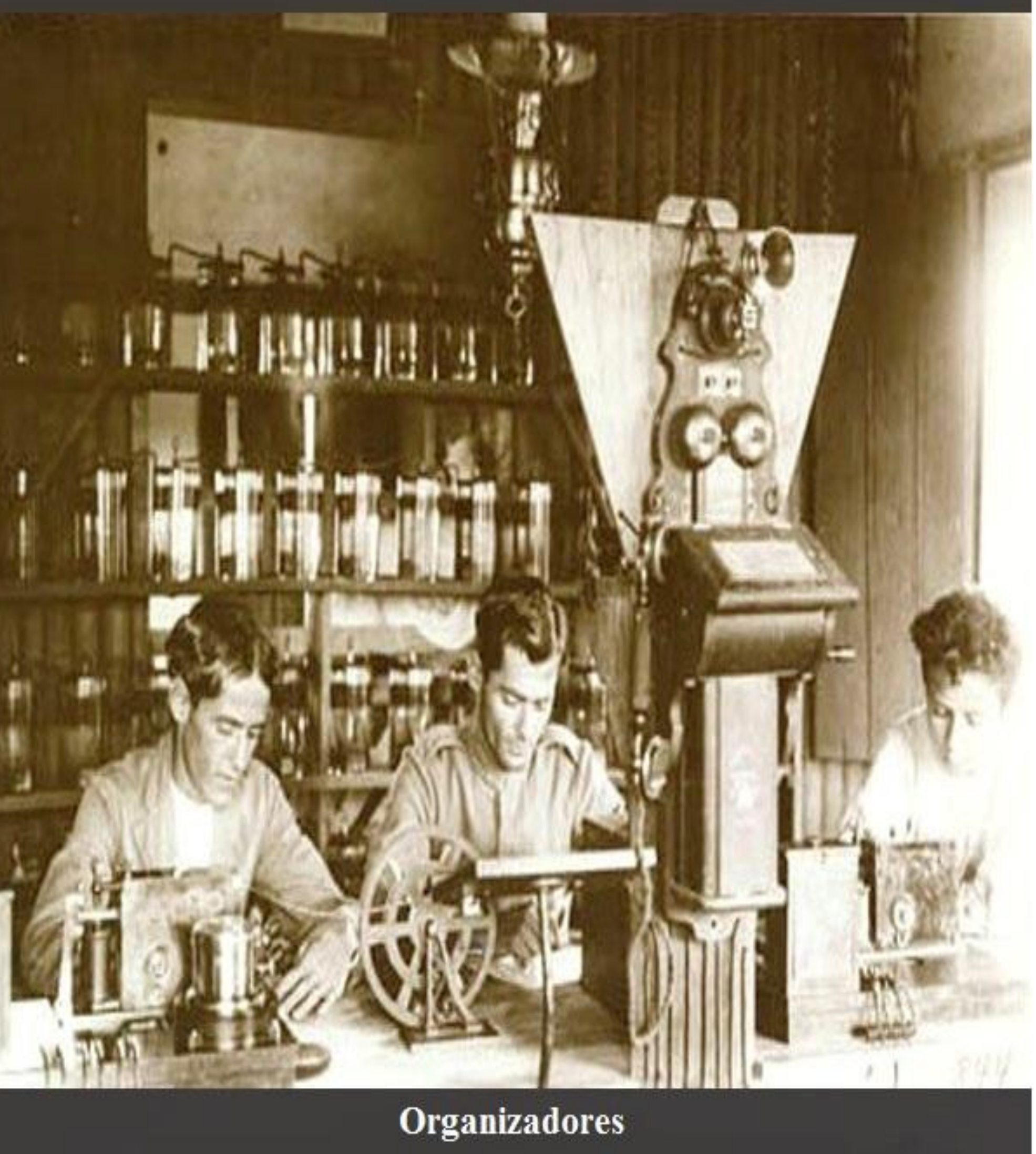

Odete Burgeile, José Lucas Pedreira Bueno 


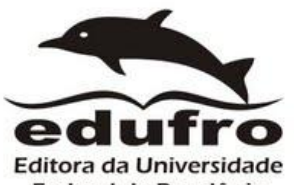

Editora da Universidade

Federal de Rondônia

Av. Presidente Dutra, 2965 - Centro

Porto Velho - RO - CEP: 76801-974

Fone: (69) 2182-2175

www.edufro.unir.br

edufro@unir.br 
Odete Burgeile

José Lucas Pedreira Bueno

Juracy Machado Pacífico

(Organizadores)

\section{Olhares da mídia na Amazônia: movimentos e manifestações}

Porto Velho-RO

2016

EDUFRO 



\title{
Ficha Catalográfica - Biblioteca Central da UNIR
}

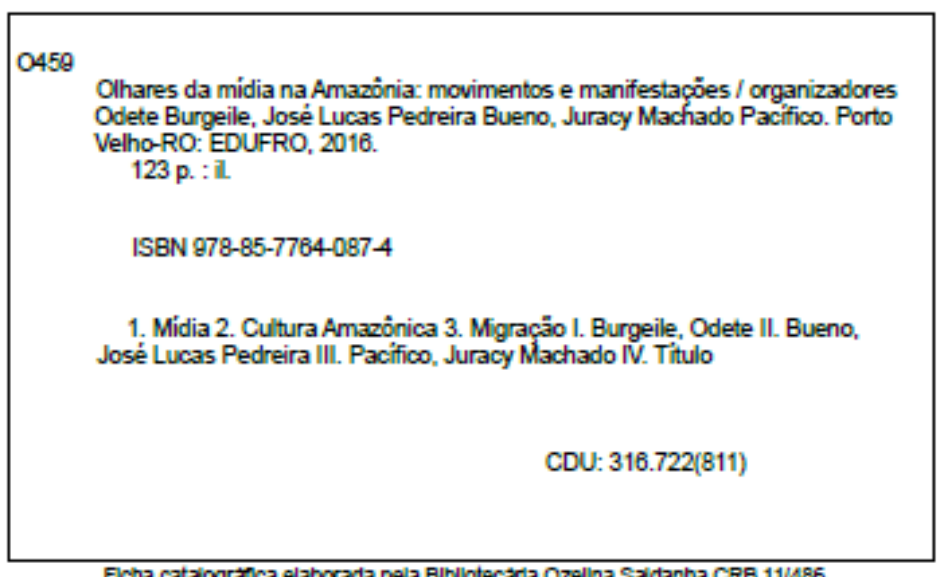

Ficha cataiogránca elaborada pela Blbliotecaria Ozellna Saldanha CRB 11/486

Preparo de originais: Autores

Revisão Gramatical: Autores

Composição: EDUFRO

Revisão de Normas Técnicas: Autores

Editor: Jairo André Schlindwein

Fundação Universidade Federal de Rondônia

\author{
Ari Miguel Teixeira Ott \\ Reitor \\ Otacílio Moreira de Carvalho Costa \\ Pró-Reitor de Planejamento \\ Marcelo Vergotti \\ Vice-Reitor \\ Jorge Luiz Coimbra de Oliveira \\ Pró-Reitora de Graduação \\ Adilson Siqueira de Andrade \\ Valdir Aparecido de Souza \\ Chefe de Gabinete \\ Pró-Reitora de Pós-Graduação e Pesquisa \\ Ivanda Soares da Silva \\ Rubens Vaz Cavalcante \\ Pró-Reitor de Administração \\ Pró-Reitor de Cultura, Extensão e Assuntos \\ Estudantis
}

Conselho Editorial da EDUFRO

Jairo André Schlindwein (Prof. UNIR), José Lucas Pedreira Bueno (Prof. UNIR), Emanuel Fernando Maia de Souza (Prof. UNIR), Rubiani de Cássia Pagotto (Profa. UNIR), Osmar Siena (Prof. UNIR), Júlio César Barreto Rocha (Prof. UNIR), Marli Lucia Tonatto Zibetti (Profa. UNIR), Sirlaine Galhardo Gomes Costa (Bibliotecária UNIR), Cléberson de Freitas Fernandes (EMBRAPA), Dante Ribeiro da Fonseca (ACLER

Depósito legal na Biblioteca Nacional conforme Lei no 10.994, 14 de dezembro de 2004.

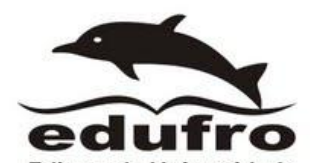

Editora da Universidade

Federal de Rondônia

Av. Presidente Dutra, 2965 - Centro

Porto Velho - RO - CEP: 76801-974

Fone: (69) 2182-2000

www.edufro.unir.br

edufro@unir.br 



\section{SOBRE A CAPA}

Numa cultura como a nossa, há muito acostumada a dividir e estilhaçar todas as coisas como meio de controlá-las, não deixa, às vezes, de ser um tanto chocante lembrar que, para efeitos práticos e operacionais, o meio é a mensagem, (McLuhan,1964, p.21).

A imagem utilizada na capa deste livro retrata um momento importante para a formação social e histórica da Amazônia. Trata-se do retrato de três telegrafistas na estação de Pimenta Bueno, trabalho realizado por um dos membros da Comissão Rondon, o fotógrafo José Louro. Contudo, não só o momento histórico é importante para ser analisado nesse contexto. O próprio meio utilizado para apresentar os acontecimentos indicava o processo de modernização pelo qual, ainda nos primeiros anos do século XX passava a Amazônia. A fotografia, assim como o cinema foram instrumentos midiáticos muito presentes nas ações do Estado a partir da formação da República brasileira. É através das imagens que a propaganda positivista toma força e possibilita a consolidação de uma nova realidade política após a tardia queda do sistema monárquico.

Por outro lado, o momento retratado por José Louro destaca a importância das comunicações no processo de criação de Rondônia e, porque não dizer, de toda Amazônia, uma vez que a realidade apresentada no interior do posto telegráfico, isso dito pelo próprio Candido Rondon (1915), não era a mesma observada em seu exterior, onde indígenas, seringueiros e regatões definiam as principais características da sociedade vigente. A presença mais intensa do Estado, a ordem estabelecida pelos grupamentos militares, os símbolos nacionais cada vez mais presentes, passaram a dar o mote para a formação de povoações com características urbanizadas e cada vez mais distantes da natureza.

A Comissão Rondon e seus postos telegráficos: Vilhena, Pimenta Bueno, Presidente Hermes, Presidente Afonso Pena, Jaru, Ariquemes, Caritianas, Jamari e Santo Antônio demarcaram o que seria, com o passar dos anos, o interior do estado de Rondônia. Justamente a partir dessas estações telegráficas que geralmente eram instaladas nas sedes de alguns barracões de seringa, formaram-se as comunidades embrionárias que demarcaram o interior desse estado.

A fotografia disponível na página eletrônica do Museu do índio possui as seguintes informações: Rondônia: Comissão Rondon. 1922. 1 fot., P\&B. $15 \mathrm{~cm}$ x $21 \mathrm{~cm}$. Fotografia pertencente ao álbum: Comissão Rondon. Linhas Telegráficas estratégicas de Mato Grosso ao Amazonas. $\quad \mathrm{O}$ endereço eletrônico é: $<$ http://base2.museudoindio.gov.br/cgibin/wxis.exe?IsisScript=phl82.xis\&cipar=phl82.cip\&lang $=$ por $>$

Washington Heleno Cavalcante 


\section{SUMÁRIO}

APRESENTAÇÃO 7

A ausência da mulher assentada na mídia rondoniense: um estudo reflexivo em torno das publicações online......

Elizabete Matia de Siqueira (UNIR)

A festa do divino espírito santo em Pimenteiras e a cobertura das novas mídias digitais: o caso dos blogs de Rondônia

Lilian Maria Moser (UNIR)

José Willians Simplicio da Silva(UNIR)

A influência das mídias e o poder simbólico das redes sociais no facebook na divulgação de eventos religiosos pentecostais e das religiões de matrizes africanas em Porto Velho ..... 35

Joel Balduino da Silva Junior(UNIR)

Miguel Nenevé (UNIR)

A utilização da mídia escrita e da caravana ford como estrátégias do governo de Rondônia para conclusão da BR-29

Washington Heleno Cavalcante (UNIR)

Çairé: cultura amazônica reinventada pelo mercado para a mídia

Raimunda Adriana Maia Costa (UFOPA)

Tânia Suely Azevedo Brasileiro (UFOPA)

Rádio e a saúde dos moradores às margens rio Purus, em Lábrea/AM

Fábio Teixeira Lima (UNIR/IFAM)

José Lucas Pedreira Bueno (UNIR)

Amazônia: cultura, mídia e política pela ótica de um massacre

Mauro Antônio dos Santos (UNIR)

A migração na visão da mídia impressa e seu papel na difusão de Rolim de Moura 95

Maria Aparecida da Silva (UNIR)

Odete Burgeile (UNIR)

O discurso sobre o Brasil na mídia e a identidade do brasileiro

Liubov Tarasova (UNIR)

Odete Burgeile (UNIR)

Élcio Aloisio Fragoso (UNIR)

Notas sobre a estética autoetnográfica no documentário

Juliano José de Araújo (UNIR) 


\section{APRESENTAÇÃO}

O livro Olhares da mídia na Amazônia: movimentos e manifestações foi produzido pelo Mestrado em História e Estudos Culturais, Mestrado Profissional em Educação Escolar, Mestrado em Letras, pelo Grupo de Estudos Linguísticos, Literários e SocioculturaisGELLSO, Grupo EDUCA - Grupo Multidisciplinar em Educação e por convidados de outra instituição.

Procuramos organizar uma obra em que pudéssemos relacionar trabalhos acerca das representações da cultura, da diversidade e da educação com as discussões científicas no contexto das comunidades da Amazônia, a partir de estudos elaborados por pesquisadores da Universidade Federal de Rondônia e da Universidade Federal do Oeste do Pará, buscando oferecer ao leitor um panorama, nunca exaustivo, de pesquisas e atuações em campos do saber que são construídos em muitas áreas do conhecimento.

É uma obra para ser lida e apreciada com as belezas da Amazônia, mas também com suas contradições: encantos e desencantos; riquezas e vida simples; exploração e preservação, dentre tantas outras. É obra para se fazer um belo voo pela Amazônia e, especialmente, por Rondônia.

Na virada do Século XXI, as mulheres já representam mais da metade da população mundial. Organismos como a Organização das Nações Unidas, a Organização Mundial do Trabalho e a Organização Mundial de Saúde, espelham a tomada de consciência e o reconhecimento da mulher como elemento chave do desenvolvimento." Com essas palavras inicia Siqueira a abertura dos trabalhos desta coletânea, tentando identificar e compreender como a mídia online, no período de 2011 a 2013, se manifesta com relação ao universo das mulheres assentadas em Rondônia, especificamente em Porto Velho, bem como as relações se estabelecem com sociedade hodierna.

Moser e Silva problematizam algumas nuances da festa do Divino Espírito Santo sob o prisma dos Estudos Culturais. Mostram como a sociedade contemporânea tem possibilitado à "humanidade" acesso às tecnologias sob os signos da praticidade e da interatividade. 
Com uma crítica à presença da mídia em alguns eventos culturais em detrimento de outros, Balduino da Silva Junior e Nenevé tratam do avanço das mídias através do Facebook, na divulgação dos eventos religiosos e simbólicos das religiões Pentecostais e Afrodescendentes em Porto Velho. Os autores mostram as diferenças existentes entre exclusão social no campo das culturas de massa.

Com as palavras "O início do governo de Juscelino Kubitschek tendo como mote 'o desenvolvimento e a ordem', foi um prenúncio de apaziguamento das mazelas ideológicas entre os militares. Por outro lado, o presidente buscou logo no início de seu governo atender as reivindicações das corporações militares, tanto na questão salarial quanto na questão técnica com a aquisição de equipamentos [...]", Cavalcante analisa os problemas que envolveram a utilização da mídia escrita e da Caravana Ford no processo de construção da BR-29, atual BR364, o que ocorreu durante o governo de Kubischek. Vale a pena conhecer essa parte da história de Rondônia.

Costa e Brasileiro desenvolvem os argumentos que sustentam a ideia de que a mídia, a indústria cultural e, fatalmente, o mercado exercem influência decisiva na concepção e construção dos eventos históricos da Amazônia.

Lima e Bueno destacam que, dentre os vários problemas enfrentados pela população do município de Lábrea/AM, a saúde pública é talvez a mais preocupante. Isso porque envolve vários fatores nas áreas econômicas, sociais e culturais, e destacam o rádio como meio de comunicação de massa, responsável pela divulgação e informação sobre os riscos da hepatite B, nos lugares mais longínquos da sede do município de Lábrea.

Santos aponta que "uma das mais constantes contradições na produção literária e histórica da Amazônia é o adjetivo a ela referido que vai de paraíso a inferno. Tais adjetivos incorporados pela literatura e popularizado pelos seus exploradores já é uma demonstração da sua singularidade cultural." O autor faz uma reflexão através dos conceitos de cultura, mídia e política para tentar mostrar como se deu a construção e desconstrução dos fatos do massacre Corumbiara que levaram ao desfecho histórico da luta por terra na Amazônia.

Silva e Burgeile discorrem sobre as contradições presentes entre a visão desenvolvimentista do Estado brasileiro para Rolim de Moura - Rondônia e a dos migrantes dessa região, através do diálogo entre as mídias impressas sobre a migração, a Roda de Conversa e os questionários aplicados com esses migrantes.

Tarasova, Burgeile e Fragoso tentam identificar as possíveis relações entre o discurso da mass mídia sobre o Brasil e a construção da identidade do sujeito. Para os autores, "consciente ou inconscientemente, os media, que inclui jornais, TV, internet, radio entre outros, tornaram-se parte importante da vida quotidiana dos sujeitos, levando-se em conta tanto a 
perspectiva individual como a perspectiva social", supondo-se, com isso, que os mass midia são efetivamente um meio de controle e de construção da sociedade.

Encerrando as seções da coletânea, Juliano Araújo traz questões para se pensar as implicações estéticas para o audiovisual de não-ficção, a partir da realização de documentários por comunidades indígenas.

Agradecemos aos autores e autoras que produziram os textos, o que possibilitou que pudéssemos agora ter um excelente trabalho e o prazer de entregar aos leitores e leitoras.

Porto Velho, setembro de 2016.

Odete Burgeile José Lucas Pedreira Bueno 


\section{A ausência da mulher assentada na mídia rondoniense: um estudo reflexivo em torno das publicações online}

Elizabete Matia de Siqueira (UNIR)

\section{Introdução}

Na virada do Século XXI, as mulheres já representam mais da metade da população mundial. Organismos como a Organização das Nações Unidas, a Organização Mundial do Trabalho e a Organização Mundial de Saúde, espelham a tomada de consciência e o reconhecimento da mulher como elemento chave do desenvolvimento. (PLANO NACIONAL DE POLÍTICAS PARA AS MULHERES, 2013, p. 07).

E no que se refere a origem dos estudos culturais sobre as mulheres é importante esclarecer que se trata de um olhar sobre a mulher reassentada, e se pretende dar espaço para um novo modo de ler as relações que foram estabelecidas no Reassentamento Santa Rita. Em que foram selecionados através de pesquisa exploratória jornais on line, para verificar se os mesmos apresentam reportagens sobre as mulheres reassentadas.

Nestes estudos culturais nos quais estão centrados a mulher poder-se-á incluir alguns conceitos propostos por Vicente (1998) como feminismo que se refere a discussão política, social ou ética sobre o lugar da mulher na sociedade; feminilidade: discussão referente ao caráter próprio da mulher; e feminidade: discussão sobre aquilo que constitui o caráter de quem é mulher.

A partir dessas definiçõos é possível constituir um estudo sobre as mulheres, incluindo o estudo das implicações culturais sobre a posição e o percurso da mulher na sociedade e o contributo feminino, muitas vezes silenciado.

Para compreendermos o cenário sobre o movimento das mulheres é preciso descrever os principais movimentos ocorridos neste Século. Busca-se nesta pesquisa, informações das notícias publicadas nos jornais online sobre as mulheres, sobre as políticas públicas de atendimento às mesmas, aos movimentos sociais e aquelas de reivindicação, no período de 2011 a 2013.

As transformações são concretas para uma parcela de mulheres, no entanto outras continuam desprovidas dos arsenais de que as classes dominantes são possuidoras. Algumas práticas, como mudanças culturais no sentido de redimensionar os papéis sociais da mulher são necessárias. Isto exige tempo e empenho, uma vez que a emancipação da mulher passa pela superação da reprodução social dos modelos tradicionais de homem e mulher.

Tomando como base esses desafios as mulheres colocam-se como prioridades a construção de políticas que lhe assegurem mais espaços de poder, equidade no trabalho, inclusão no desenvolvimento. E isso ocorrerá se houver democratização da mídia que, às vezes, contribui 
para a invisibilidade do protagonismo das mulheres, haja vista a ausência de publicações sobre participação e atuação destas na superação das expressões cotidianas e da opressão, as quais continuam submetidas.

$\mathrm{O}$ artigo apresenta um breve relato histórico sobre o movimento das mulheres assentadas. E no segundo momento nos mostra como a mídia online retrata a mulher reassentada, o movimento de participação e o seu legado para a sustentabilidade e nas considerações finais as questões colocadas sobre a mídia online, encontrou-se poucas informações sobre as mulheres reassentadas, apenas restringe-se a fatos relacionados à violência contra a mulher.

\section{Breve relato histórico sobre o movimento das mulheres assentadas no Brasil a partir do século XXI}

Ao estabelecer a democracia no país, a Constituição Federal de 1988 é um marco legal que coloca as mulheres em condições de igualdade aos homens. Mas as conquistas de direitos das mulheres esbarram em muitos desafios já que muitos direitos somente são assegurados no papel.

De acordo com os dados do IBGE (2012), 37,3\% das famílias brasileiras são chefiadas por mulheres; e há muitas mulheres emancipadas, mas outras tantas ainda continuam carregando sozinhas o peso dessas mudanças conjunturais como a pobreza, procriação dos filhos, afazeres domésticos e ajudam no aumento da renda da família e, muitas vezes, são a principal geradora de fonte de renda. Para compreender o cenário sobre o movimento das mulheres é preciso descrever os principais movimentos ocorridos neste século.

\subsection{Movimentos de mulheres no brasil}

As políticas para as mulheres têm avançado significativamente a partir da perspectiva do diálogo e a construção coletiva, conforme o Plano Nacional de Políticas para as Mulheres (2013). Os movimentos de mulheres feministas e demais movimentos sociais se apresentam com cunho de reverter as lógicas desiguais perante a nossa sociedade há séculos.

Observa-se que desde a criação da Secretaria de Políticas para Mulheres, em março de 2003, buscou-se consolidar o amadurecimento de tais políticas, a partir do diálogo permanente entre governo e sociedade civil, com o fito de reforçar o princípio de que um estado plenamente democrático só o é se for possibilitada a condição da participação social, sobretudo das mulheres.

Tais políticas têm sido fomentadas por meio de Conferências, segundo o Plano Nacional de Políticas para as Mulheres (PNPM, 2013, p.09): a I Conferência Nacional de Políticas para as Mulheres, em julho de 2004, contou com 1.787 delegadas que debateram as suas agendas e elaboraram o I Plano Nacional de Políticas para Mulheres. O processo como um todo envolveu mais de 120 mil mulheres em todas as regiões do país. Já a II Conferência Nacional de Políticas para as Mulheres, que ocorreu em agosto de 2007, contou com a participação de 200 mil mulheres. O resultado deste evento foi a elaboração do II Plano Nacional de Políticas para Mulheres. E no ano de 2011, em dezembro, aconteceu a III Conferência Nacional de Políticas para Mulheres, cujos resultados inseriram as temáticas de gênero em diversas frentes e estabeleceu um plano a ser executado no biênio 2013 a 2015. 
O documento que referenda o Plano de Políticas para as Mulheres cita na parte introdutória a seguinte afirmativa:

\begin{abstract}
No mandato de Dilma Rousseff, primeira mulher presidenta do Brasil, o Plano Nacional de Políticas para as Mulheres torna-se um instrumento ainda mais importante, tendo em vista que, em seu governo, a Secretaria de Políticas para as Mulheres assume maior protagonismo e liderança - como reafirmado pela presidenta em sua fala durante a $3^{\text {a }}$ Conferência Nacional de Políticas para as Mulheres: "Eu tenho o compromisso inabalável - e reafirmo aqui - de aprofundar as políticas de igualdade de gênero no nosso país" (2013, p.09).
\end{abstract}

Tal perspectiva mostra o cenário político e histórico do enfrentamento massivo à violência e à discriminação, bem como demonstra a amplitude das políticas públicas indicando o propósito político de efetivar programas com resultados específicos.

Assim, as políticas para as mulheres permitem que haja articulação de órgãos competentes para a execução de inclusão sociopolítica das diferenças tanto no espaço privado quanto no espaço público, permitindo que o estado como um todo seja a base de políticas para as mulheres, na medida em que considera todas as formas de desigualdade e permita o enfrentamento do problema por inteiro.

Ao buscar o direito à vida de qualidade das mulheres no meio rural, as políticas públicas também respeitam as especificidades das mulheres do campo, e faz-se necessário conhecer o movimento de mulheres assentadas na Região Amazônica, para conhecê-las como protagonista na ocupação do território.

\title{
2.2. Movimentos de mulheres assentadas na região amazônica: o olhar da mídia online
}

A Amazônia de uma enorme diversidade cultural, formada por quilombolas, seringueiros, povos da floresta, ribeirinhos e os migrantes na ocupação do espaço, contou com participação efetiva, direta e indireta das mulheres que junto aos homens constituíram a formação dos novos grupos sociais, inclusive dos reassentamentos.

O reconhecimento da contribuição da mulher para a produção e reprodução dos bens da família, ainda é desalentadora na sociedade, não só pelo fato da ausência de reconhecimento como trabalhadora, mas também por poucos estudos acadêmicos sobre a história das mulheres assentadas, principalmente na região amazônica, mais especificamente em Rondônia.

Cabe observar que Rondônia, estado da Região Amazônica, em 2008, passa por momento marcante no desenvolvimento econômico e social, motivado pela construção das usinas do Rio Madeira que provocou uma verdadeira revolução na vida dos habitantes, principalmente em Porto Velho e seus arredores. A hidrelétrica Santo Antônio, segundo o site oficial da empresa, já investiu R 939 milhões em ações de sustentabilidade, como reassentamento, resgate de fauna e flora, além de investimentos em educação, saúde e segurança, segundo informações da mídia institucional da Empresa Santo Antônio Energia (2011).

Para remanejar as famílias atingidas pela barragem foram implementados sete reassentamentos: Santa Rita, Novo Engenho Velho, São Domingos, Riacho Azul, Vila de Teotônio, Morrinhos e Parque dos Buritis. Segundo o Movimento dos Atingidos por Barragens (MAB), todos os reassentamentos foram criados sem seguir um mesmo padrão, conforme dados na página online do Movimento dos Atingidos por Barragem - MAB, (2011). 
O MAB (2011) publicou em suas páginas online:

\begin{abstract}
A inexistência de uma política nacional que garanta os direitos mínimos as famílias atingidas concede total liberdade para que as empresas construtoras adotem uma política discriminatória, preconceituosa, injusta e autoritária de tratamento com as famílias, condicionada apenas a seus interesses lucrativos, a tal ponto que os atingidos de Rondônia, formados em grande parte por ribeirinhos, pescadores, agricultores e extrativistas estão sendo remanejados para vilas urbanas sem ter terra, água, acesso ao rio, trabalho, renda e escolas adequadas. (2011, p. online).
\end{abstract}

Existem contradições sobre os reassentamentos. As famílias são atingidas pela mesma barragem, mas, mesmo assim, o tratamento é diferenciado, com casas e terras com áreas diferentes. Segundo o MAB (2011), as famílias não foram consultadas a respeito de como deveria ser construída sua nova morada. A empresa Santo Antônio Energia - SAE impôs um modelo de reassentamento e que está com sérios problemas. O movimento informa ainda, que somente no reassentamento Santa Rita, o MAB e o Instituto Nacional de Colonização e Reforma Agrária - INCRA participaram das negociações com as famílias reassentadas e a SAE, portanto o único reassentamento em que as casas foram construídas com $100 \mathrm{~m}^{2}$.

Diante de tantos problemas o MAB apresentou uma pauta de reivindicações para garantir direitos básicos das famílias assentadas pelas usinas:

1- Prorrogação da Verba de Manutenção: Que o auxilio dado às famílias (verba de manutenção) seja prorrogado até que as mesmas tenham capacidade de produzir e sobreviver com a renda a partir de sua própria produção.

2- Terra Preparada: Que todas as famílias tenham sua área de produção individual totalmente preparada, mecanizada e corrigida corretamente em condições de produzir.

3- Água para Todos: Que todas as famílias de todos os reassentamentos tenham um poço artesiano de qualidade e uma caixa de 5 mil litros para ter o abastecimento de água satisfatório tanto para consumo quanto para a produção.

4- Direitos iguais para todos reassentamentos: Que todas as áreas de reassentamento tenham os mesmos direitos: patrulha de maquinas agrícolas e todos implementos, galpão, 50 hectares de terra para todos; estradas; moradias.

5- Exigimos a solução imediata das áreas de reserva legal de todos os Reassentamento: compra imediata dos 40 hectares por famílias em todos os reassentamentos.

6- Pagamento pela empresa de todas as contas referentes às tarifas de energia elétrica e de água até que as famílias tenham renda de sua produção.

7- Solução de todas as demais pendências existentes em cada reassentamento. (2011, p. online.).

As dificuldades apresentadas diferem do discurso usado pela empresa Santo Antônio Energia quando apresenta todo seu plano de investimento em ações de sustentabilidade, incluindo os reassentamentos, pois o relatório da Dhesca Brasil ${ }^{1}$ confirma a violações dos direitos humanos.

A relatoria Nacional do Direito Humano ao Meio Ambiente - Plataforma Dhesca Brasil (2011), em monitoramento visando investigar as denúncias de violações de direitos humanos relacionados às obras das usinas hidrelétricas do Complexo do Rio Madeira em Porto Velho-RO, concluíram, entre várias violações:

No reassentamento de populações verificou-se reclamação generalizada de piora das condições de vida por redução da receita das populações removidas, assim como de má qualidade na construção das casas e vias públicas. (2011 p.03).

\footnotetext{
${ }^{1}$ Plataforma Brasileira de Direitos Humanos, Econômicos, Sociais, Culturais e Ambientais - DHESCA. 
Continuando, o relatório Dhesca (2011, p.4) aponta:

O número de homicídios dolosos cresceu 44\% em Porto Velho entre 2008 e 2007, e a quantidade de crianças e adolescentes vítimas de abuso ou exploração sexual subiu 18\%. O número de estupros cresceu 208\% em Porto Velho entre 2007 e 2010.

Percebe-se que diante de tão grande movimento, as minorias são as maiores vítimas, seja por exploração sexual ou estupro, vitimando principalmente as crianças, adolescentes e mulheres, que nas reportagens online, durante esse período pesquisado, aparecem apenas como vítimas e não como protagonistas de sua história.

Pelo fato das mulheres não serem vistas como protagonistas na mídia, reportamonos a Escosteguy (2001) ao afirmar que a partir da segunda metade da Década de 1970, os primeiros estudos culturais desenvolveram trabalhos que se concentraram nos meios de comunicação de massa que, além de entreter, eram também vistos como aparelhos ideológicos do Estado (grifo nosso).

Ao que se nota os meios de comunicação online pesquisados podem ser vistos como aqueles que não apresentam todos os dados conforme os denunciados pelo MAB e o relatório da Dhesca Brasil. Estabelece portanto a hipótese de que a mídia institucional apenas reproduz o discurso dominante e a mídia não institucional não se manifesta.

É obvio que as informações publicadas pela mídia podem apresentar conceitos, valores que nem sempre representam o pensamento de um grupo, ou seja, pode vir distorcido, por isso é importante investigar e contrapor a notícia, como neste caso, muitos dados publicados pela Usina são contrapostos pelo Relatório Dhesca.

Em Zoonnen (1996, p. 30) apud MESSA (2006), destaca dois conceitos recorrentes nas abordagens sobre mídia: "distorção" e "socialização". Como distorção entende-se o modo como a mídia nos faz acreditar em uma realidade que não existe. Já como socialização, entendese o processo pelo qual assimilamos os valores simbólicos correntes em nossa sociedade, que nos permitem posicionarmo-nos nesta com determinado status ou papel.

E assim, vejam como a mídia rondoniense trata as questões da mulher reassentada.

\section{A mulher reassentada: o que dizem as reportagens online na mídia rondoniense}

Nesta pesquisa, buscou se investigar de que forma a mídia escreve sobre a mulher assentada na reforma agrária, em jornais online de Porto Velho. Foram selecionados 05 (cinco) jornais online com notícias sobre mulheres assentadas para análise e discussões.

Cabe considerar que a mídia, segundo Fischer (2001), é um lugar privilegiado de criação, reforço e circulação dos sentidos, que operam na formação de identidades individuais e sociais, bem como na produção social de inclusões, exclusões e diferenças - temas fundamentais hoje nos mais diversos campos das ciências humanas.

A pesquisa exploratória deu-se a partir de jornais online, como por exemplo: Tudo Rondônia, O Observador, Rondônia ao Vivo, Rondônia Dinâmica, Rondonotícias. Realizou-se uma pesquisa no Google e constatou-se a existência de 43 (quarenta e três) ${ }^{2}$ Jornais online na região. Destes jornais selecionados encontraram-se notícias sobre mulheres, publicadas no período de 2012 e 2013, mas não notícias específicas sobre as mulheres assentadas.

\footnotetext{
${ }^{2}$ Disponível em: <http://www.guiademidia.com.br> Acesso em: 24 jan. 2014.
} 
As notícias, em sua maioria, tratam sobre os assentamentos ou reassentamentos e são reproduções de informações dos órgãos oficiais, que em suas páginas online divulgam pautas sobre o tema.

E no caso específico de Rondônia uma única notícia no ano de 2012, no Jornal Rondônia Dinâmica ${ }^{3}$, de 07 de março, afirma que as mulheres rurais são prioridade nos assentamentos da reforma agrária em Rondônia. Acrescenta que o INCRA desenvolve ações permanentes nos assentamentos como o Programa de Documentação da Mulher Trabalhadora Rural, o Crédito Apoio Mulher, assistência técnica e sua inclusão na titularidade de lotes, cadastramentos e contratos.

Percebe-se que a mídia online reproduz o que está nos sites institucionalizados, como o caso dos Programas de Atendimento à mulher rural, visto no site do Ministério de Desenvolvimento Agrário - MDA, cuja matéria é a mesma no Jornal Rondônia Dinâmica.

O site oficial do Ministério de Desenvolvimento Agrário - MDA e do INCRA, ao falar das mulheres assentadas, afirma que a partir do movimento dos assentados e outros movimentos, o Governo Federal, reconhece as desigualdades de gênero, implanta um conjunto de políticas públicas de apoio às mulheres rurais, possibilita a inclusão como beneficiárias diretas, afirmando o seu protagonismo e promovendo a autonomia econômica, dando acesso à documentação e a política de apoio à produção e comercialização, como também direito ao título da terra. O Ministério de Desenvolvimento Agrário - MDA, através da Diretoria de Políticas para as Mulheres Rurais e Quilombolas desenvolveu políticas para a redução das desigualdades de gênero no meio rural.

Entre as políticas implantadas pelo governo federal através do Ministério de Desenvolvimento Agrário, destaca-se o Programa Nacional de Documentação da Trabalhadora Rural -PNDTR, que garante às mulheres rurais o acesso a documentos civis e trabalhistas.

O Programa Nacional de Reforma Agrária, pela Portaria 981/2003, do Instituto Nacional de Reforma Agrária - INCRA inclui as mulheres na regularização e titulação do Certificado de Cadastro de Imóvel Rural, juntamente com o homem, independente do estado civil. A Instrução Normativa 38/2007, do INCRA, garante às famílias chefiadas por mulheres a prioridade na classificação das mesmas para o beneficio da Reforma Agrária, garantindo o acesso e direito das mulheres à terra.

Segundo Mourão (2010), “o Programa de Fortalecimento da Agricultura Familiar (PRONAF) com uma linha de crédito especial, o PRONAF Mulher, com o objetivo de reconhecer e estimular o trabalho das mulheres rurais na agricultura familiar e nos assentamentos da reforma agrária financia as atividades desenvolvidas pelas mulheres de maneira individual ou coletiva". O PRONAF Mulher é um instrumento de fortalecimento da produção das mulheres rurais e superação da invisibilidade do trabalho feminino.

Continuando Mourão (2010), afirma que “em 2008, foi criado o Programa de Organização Produtiva das Mulheres Rurais - POPMR, pela Portaria Interministerial 02, publicada no Diário Oficial da União (DOU), de 24 de setembro de 2008". Programa Interministerial do Ministério do Desenvolvimento Agrário - MDA, Ministério de Desenvolvimento Social e Combate a Fome (MDS), Ministério do Trabalho e Emprego -MTE, Ministério da Pesca e Aquicultura - MPA Secretaria de Políticas para Mulheres SPM, Instituto Nacional de Reforma Agrária - INCRA, Companhia Nacional de Abastecimento - CONAB, com a finalidade de articular as políticas de fortalecimento das organizações de mulheres rurais,

\footnotetext{
${ }^{3}$ Disponível em: <http://www.rondoniadinamica.com.br> Acesso em: 24 jan. 2014.
} 
garantindo acesso às políticas de apoio à produção e comercialização, promovendo autonomia econômica e incentiva à troca de informações, conhecimentos técnicos, culturais, valorização da economia solidária.

As políticas impulsionam a organização das mulheres, mas ainda precisam de ampliação e fortalecimento, com maior participação das mesmas e ações de promoção da igualdade de gênero, haja vista, que a mídia embora cite tais programas, vê-se que essas informações falam de políticas para as mulheres e não das mulheres no contexto, embora elas tenham papel preponderante na fixação do homem, dos filhos e filhas na comunidade, mesmo com todas as dificuldades, conforme afirma Bechimol apud Fechine (2007, p. 22):

\begin{abstract}
A Mulher é o elemento fixador por excelência. Dá o sentido de estabilização e permanência na terra em uma imigração bem dirigida. No entanto, sendo quase sempre sentimental por índole, e mais chegada aos hábitos e costumes, é quem vai sofrer mais a mudança de ambiente [...]. Em todas as mulheres que entrevistei, sentia sempre um desgosto, um desânimo quando não revolta incontida. 'Não haverá mais sossego para mim numa terra em que eu não conheço ninguém. A falta de aconchego do lar, da paisagem doméstica, dos parentes e dos amigos, da 'convivência' como eles chamam, atua poderosamente para isso.
\end{abstract}

As transformações são concretas para uma parcela de mulheres, no entanto outras continuam desprovidas dos arsenais de que as classes dominantes são possuidoras. Algumas práticas, como mudanças culturais no sentido de redimensionar os papéis sociais da mulher são necessárias. Isto exige tempo e empenho, uma vez que a emancipação da mulher passa pela superação da reprodução social dos modelos tradicionais de homem e mulher.

Segundo Messa (2006), "ser feminista, no Século XXI, não significa excluir o homem da relação, como se fosse o patriarcado culpado de todos os males que afligem a mulher”. Também não significa que homens e mulheres precisam ser iguais, mas indica que na diferença não deve residir nenhum tipo de preconceito.

A notícia do jornal online Rondônia Dinâmica, de 07 de março de 2012, ainda destaca que a assistência técnica do Incra está orientada para integrar todos os membros do grupo familiar, como homens, mulheres, jovens e idosos. A família passou a ser compreendida a partir da participação de todos os seus membros, sendo reconhecidos novos arranjos sociais, inclusive com as mulheres chefes de família.

Diante de tamanha importância do papel da mulher, a assentada assume uma dupla responsabilidade, a de ser mulher e ser assentada.

\title{
3.1. O legado de sustentabilidade das mulheres assentadas e seu movimento de participação
}

Segundo Jalil (2009), "uma nova ordem econômica e mundial se iniciou no final da Década de 1970". A política neoliberal acirrou as desigualdades sociais e abriu espaço para a entrada de um novo tipo de capital, fortalecendo o agronegócio, a indústria de sementes, insumos e agrotóxicos, a tecnologia dos equipamentos, a flexibilização da legislação trabalhista e ambiental, o latifúndio e a monocultura. Esta nova ordem refletiu nas populações rurais, principalmente na vida das mulheres, pois, elas são as 'responsáveis' pelo cuidado da família e ainda pela manutenção da diversidade, o cuidado das sementes e a agricultura de subsistência. 
Com a democratização do país e a Constituição Federal de 1988, aumentou a participação dos atores sociais nas instituições políticas. Este processo propõe mudanças estruturais, políticas e culturais bem como retomar o significado de uma democracia participativa, por meio dos movimentos sociais.

Segundo Carneiro apud JALIL (2009, p. 6):

É neste ambiente e no bojo das transformações políticas que, no Brasil os movimentos das mulheres ganham força e significativa expressão nos processos de lutas no campo e datam deste período as primeiras organizações formais com o objetivo de reivindicar o reconhecimento político de um estatuto profissional, bem como de outros direitos sociais.

O movimento incorpora novas demandas e questionamentos, como a divisão sexual do trabalho, a violência sexista, a participação das mulheres nos partidos políticos, sindicatos, associações, levando a uma mudança das ações de luta e como estas vão ocorrer.

As primeiras organizações a surgirem segundo Jalil (2009, p. 5) foram:

\begin{abstract}
Movimento Popular de Mulheres do Paraná (MPMP), em 1983; Movimento das Mulheres Agricultoras de Santa Catarina (MMA-SC), em 1984; Movimento das Mulheres Assentadas de São Paulo (MMA-SP), em 1985; Movimento de Mulheres Trabalhadoras Rurais do Rio Grande do Sul (MMTR-RS, em 1985; Comissão Estadual de Mulheres da Federação dos Trabalhadores de Rondônia (CEM/FETAGRO, em 1985; Associação de Mulheres Trabalhadoras Rurais do Espírito Santo (AMUTRES), em 1986; Movimento das Trabalhadoras Rurais do Nordeste (MMTR-NE), e 1986; Centro de Associações de Mulheres Trabalhadoras do Acre (CAMUTRA), em 1987; Articulação das Instâncias das Mulheres Trabalhadoras Rurais-Sul (1988) e a Comissão Nacional de Mulheres Trabalhadoras Rurais da Central Única dos Trabalhadores (CNMTR-CUT), em 1990.
\end{abstract}

Os questionamentos e lutas enfatizados nos movimentos foram e são indispensáveis para um processo de democratização, ampliando o acesso a direitos sociais o que leva a uma transformação das relações de poder.

Como resultado do envolvimento das mulheres agricultoras em várias organizações, surge o Movimento das Mulheres Camponesas - MMC, em 2003, quando as mesmas organizam várias discussões com sindicatos e movimentos sociais, realizando de 21 a 24 de setembro de 2003 o I Curso Nacional, com representação de 14 estados e participação de 50 mulheres, representando os Movimentos Autônomos. Assim nascia o MMC com princípio político e as diretrizes:

Construir um movimento nacional das mulheres camponesas se justifica a partir da certeza de que "a libertação da mulher é obra da própria mulher, fruto da organização e da luta" (MMC). ${ }^{4}$

O MMC é o único movimento feminista que compõe a Via Campesina ${ }^{5}$ no Brasil. A luta central do MMC é contra o "modelo capitalista e patriarcal e pela construção de uma sociedade com igualdade de direitos". Sua principal bandeira de luta hoje é o "Projeto de

\footnotetext{
${ }^{4}$ Nota de apresentação do movimento em sua página: <http://www.mmcbrasil.com.br/site/node/47> Acesso em: 26 jul. 2013.

${ }_{5}^{5}$ A Via Campesina é um movimento internacional que coordena organizações camponesas de pequenos e médios agricultores, trabalhadores agrícolas, mulheres camponesas e comunidades indígenas da Ásia, África, América e Europa. Trata-se de um movimento autônomo e pluralista.
} 
Agricultura Camponesa Ecológico, com uma prática feminista, fundamentado na defesa da vida, na mudança das relações humanas e sociais e na conquista de direitos", tais bandeiras de lutas contextualizam a mulher e a sua relação com a sociedade no campo.

O Projeto "Popular de Agricultura Camponesa" do Movimento das Mulheres Camponesas - MMC busca viabilizar políticas públicas que o projeto propõe para a "agricultura que garantam a permanência no campo, a produção de alimentos saudáveis, crédito especial para mulheres, etc.; a soberania alimentar; cuidado, respeito e preservação do ambiente"; e no que se refere ao "uso sustentável dos recursos naturais"; quanto à "preservação das nascentes de águas; revitalização do Rio São Francisco; preservação das plantas medicinais e sementes crioulas"; já para o "direito e o acesso à terra; produção agroecológica de alimentos; garantia de geração de renda; valorização e valoração do trabalho e renda gerada pelas mulheres, garantindo sua autonomia"; bem como "incentivar e fortalecer a concretização de cooperação solidária"; e na produção de alimentos propõe facilitar a produção de alimentos com o auxilio da ciência, voltada aos interesses das camponesas; e aos movimentos coletivos assevera que a:

organização coletiva do grupo familiar na construção de novas formas de vivência e convivência de maneira a superar as relações da família patriarcal e machista"; e tal construção dar-se-á a partir da "construção coletiva de espaços de poder partilhado de mulheres e homens tanto nos espaços privados quanto nos públicos"; com relação as mudanças nas relações humanas e a diversidade estabelece o "respeito a diversidade étnico racial, de gênero, econômica, cultural, ecológica, e de espiritualidade; fortalecimento da arte e da cultura camponesa através de crenças, rezas, rituais, visitas, pratos típicos, mutirões de trabalho, danças, roda de viola, literatura de cordel, repentes, festas típicas e outras; valorização e reconhecimento do saber popular, fruto da herança e do conhecimento da vida camponesa; garantia da autonomia de camponesas e camponeses sobre o processo de trabalho" (MMC, 2013, p. online)

Tudo isto reflete sobre o seu corpo e sobre o seu modo próprio de vida.

A segunda bandeira de luta do MMC é pela "Ampliação dos Direitos Sociais" que tem por objetivo a garantia do direito à Previdência Pública e Universal que assegure e efetive os direitos e benefícios já conquistados, bem como a ampliação de direitos sociais; no que concerne a garantia do direito à Saúde Púbica; assim como a garantia de documentação para todas as mulheres e seus familiares; direito à educação pública de qualidade, libertadora e emancipatória; garantia de acesso aos direitos conquistados na Lei Orgânica da Assistência Social; para a "garantia de moradia digna, saneamento, luz e estradas, lazer e atividades culturais; investimento público na pesquisa, ciência e tecnologias a serviço da vida; garantia de políticas públicas de combate à violência e proteção de mulheres e crianças"; também prevê a "política de comercialização e aquisição direta de alimentos e produtos da agricultura camponesa".

Com o Projeto Popular para o Brasil o MMC tem por objetivo central "lutar pela soberania nacional, proteção, conservação e preservação da biodiversidade, recuperando, valorizando a cultura brasileira, fortalecendo as iniciativas de poder popular que reafirmam a busca da dignidade e autonomia da mulher e do povo brasileiro".

A quarta bandeira de luta do MMC é pela:

Participação política da mulher na sociedade pela participação, valorização e autonomia da mulher em todos os espaços de decisão sobre a produção, o patrimônio, as relações humanas, políticas e comunitárias, de maneira a garantir a manutenção e o avanço do campesinato, na construção de um projeto popular para o Brasil; garantia de 
autonomia e não mercantilização do corpo das mulheres com o fim de todas as formas de violência, opressão, discriminação e dominação praticada contra as mulheres e a classe trabalhadora. (MMC, 2013, p. online)

A questão é compreender como os movimentos organizados se colocam frente à problematização, questionamento e enfrentamento das relações sociais, políticas, culturais e econômicas que são a base das relações sociais.

Nas diversas culturas, as relações sociais e as organizações se diferenciam de acordo com a divisão social do trabalho e na lógica da cultura patriarcal. Recorremos a categoria de gênero, para uma melhor compreensão das formas de relações e de poder. Gênero aqui entendido segundo Jalil, (2009, p. 10):

Como um conjunto de normas, valores, costumes e práticas socialmente construídas e que através das quais a diferença biológica entre homens e mulheres é culturalmente significada, gerando hierarquia e relações de poder.

É importante entender que, se cultura surge de todo um modo de vida, é de esperar que a cultura camponesa varie segundo diferenças ecológicas, além das sociais; diferenças no ambiente físico implicam diferenças na cultura material e estimulam também diferentes atitudes como afirma Burke (2010, p.59).

Percebe-se que os movimentos organizados das mulheres a partir de suas práticas, reafirmam a luta de transformação da sociedade como instrumento político, reafirmando às mulheres o papel de protagonistas do enfrentamento ao modelo capitalista e patriarcal.

Podemos dizer que o futuro depende do reconhecimento da importância das mulheres e a necessidade de se consolidar o papel das mulheres para o desenvolvimento. Prahalad apud Freitas eti alli (2010, p.786) afirma:

Porque as mulheres podem organizar suas vidas muito mais rápido. As famílias permanecem juntas pela mulher. Elas se preocupam com suas crianças, e querem que a vida delas seja mudada. Milhares de mulheres na Índia, por exemplo, estão sendo motivadas, e estão começando a poupar e ter algum dinheiro. [...] Atualmente pessoas pobres devem ser empreendedoras para sobreviver e mulheres são boas nisso. São suas regras de sobrevivência. Se você escutar essas pessoas, você vai aprender que elas não são estúpidas. Elas são tão espertas. Elas pensam a vida em algumas formas profundas. [...] E elas não estão pedindo favores. Estão pedindo uma chance. E uma chance é tudo que podemos dar. Dê a elas a chance, e elas serão empreendedoras.

Ao viabilizar para as mulheres igualdade de oportunidades, fortalece-las e ampliar a participação na economia, a proposição acima coloca a mulher como empreendedora.

Segundo Butto apud Mourão (2010, p. 5):

Os movimentos sociais de mulheres e sua auto organização foram capazes de transformar relações na família, garantir sua participação em organizações mista e impulsionar o Estado a elaborar políticas públicas voltadas para a promoção da sua autonomia econômica.

A participação das mulheres fica evidenciada no texto acima e sabe-se que as organizações têm proporcionado novas reflexões sobre sua própria situação e aquilo que se passa a sua volta. Confirmando Beauvoir (1949) que afirma: "ninguém nasce mulher: torna-se mulher". 


\section{Considerações finais}

Os estudos culturais em torno das mulheres muitas vezes estão ligados diretamente a movimentos e práticas no sentido de redimensionar seu papel no espaço em que vive. Nada mais é do que assegurar espaços de poder.

Ao se fazer a historicização de movimento de mulheres assentadas no Brasil a partir de Século XXI, um dos marcos de diálogo e de construção coletiva para reverter as lógicas desiguais é o ano de 2003, que, com a criação da Secretaria de Políticas para Mulheres, reforça o princípio democrático de possibilitar às mulheres a condição de partícipe em ações que as mulheres exerçam liderança e protagonismo, aprofundando as políticas de igualdade de gênero.

Ao se referir sobre o movimento das mulheres assentadas na região Amazônica sob o olhar da mídia, constatou-se que a mulher assentada ainda é invisível no cenário amazônico.

Percebeu-se que no movimento resultante dos assentamentos em decorrência da construção das usinas, o discurso midiático imprimiu, de certa maneira, as violações dos direitos humanos relacionados as minorias e em sua maioria mulheres.

Constatamos nos jornais online algumas notícias sobre mulheres, mas não encontrou-se notas específicas sobre as mulheres assentadas. E as notas encontradas nada mais eram que reprodução das informações dos órgãos oficiais.

O legado de sustentabilidade das mulheres assentadas e seu movimento de participação são reflexos das mudanças estruturais, políticas e culturais, resultante da democratização do país, a partir da Constituição Cidadã, de 1988.

A questão colocada sobre a mídia, embora ela ainda não tenha dado a devida visibilidade ao papel da mulher assentada, é inegável que a participação das mulheres nas organizações proporcionou novas reflexões sobre a própria situação e aquilo que passa a sua volta.

Em suma, ao tratar do tema das mulheres assentadas e seus direitos e veiculá-lo à mídia vai incentivar outras mulheres a produzirem escritas que falam e relatam a condição de mulher reassentada.

\section{Referências}

AGÊNCIA Canal Energia. Santo Antônio Energia investe mais de R\$ 1 bi para deixar legado de sustentabilidade. Disponível em: <www.intertechne.com.br/index.php?option=com_content\&task=view\&id=178\&Itemid=2>

Acesso em: 4 jan. 2014.

BEAUVOIR. Simone de, O segundo sexo. Vol. 2. Circulo do Livro S/A. São Paulo.

BURKE, Peter. Cultura popular na idade moderna. Tradução Denise Bottmann. São Paulo: Companhia das Letras, 2010.

BRASIL. Constituição Federal, 1988. Disponível em: <www.planalto.gov.br/ccivil_03/Constituicao/Constituicao.htm> Acesso em 26 dez. 2013. 
BRASIL. Anais $3^{\mathbf{a}}$ Conferência Nacional de Políticas para as Mulheres. Disponível em: <http://www.spm.gov.br/assuntos/pnpm/publicacoes/anais-da-3a-conferencia>. Acesso em: 18 jan. 2014.

BRASIL. IBGE: população. Disponível em: <www.ibge.gov.br/apps/população/projeção>. Acesso em: 08 jan. 2014.

BRASIL. Plano Nacional de Políticas para as Mulheres. Secretaria de Políticas para as mulheres. Brasília 2013. Disponível em: <http:/spm.gov.br/pnpm/publicações/plano-nacionalde-politicas-para-as-mulheres-2013>. Acesso em: 2 jan. 2014.

CEVASCO, Maria Elisa. Dez lições sobre Estudos Culturais. São Paulo: Boitempo, 2003.

DHESCA Brasil. Relatoria Nacional para o Direito Humano ao Meio Ambiente. Dispinível em: www.dhescabrasill.org.br. Acesso em: 2 jan. 2014.

ESCOSTEGUY, Ana Carolina. Cartografia dos Estudos Culturais: uma versão latinoamericana. Belo Horizonte: Autentica, 2001.

FECHINE, Elaine Filgueiras Gonçalves. Mulheres Ribeirinhas do Rio Madeira: cotidiano envolto em brumas/Dissertação de Mestrado em Desenvolvimento Regional. Porto Velho, 2007.

FISCHER, Rosa Maria Bueno. Televisão \& Educação: fruir e pensar a TV. Belo Horizonte: Autêntica Editora, 2001.

FREITAS, Aline da Silva; BARBOSA, Maria Cristina Mesquita; BARBOSA, Suzana Mesquita. Novos paradigmas, nova mulher, nova educação: In: BERTOLIN. Patrícia Tuma Martins; ANDREUCCI. Claudia Pompeu Torezan, (org.). Mulher, sociedade e direitos humanos. São Paulo: Rideel, 2010.

GUIA Rondônia. Disponível em: <www.guiademidia.com.br/rondonia/jornais-de-portovelho.htm> Acesso em: 26 jan. 2014

JALIL, Laeticia Medeiros. Mulheres e Soberania Alimentar: um caminho para a democratização do meio rural brasileiro. XIV Congresso Brasileiro de Sociologia. 28 a 31 de julho de 2009, Rio de Janeiro. Disponível em: <www.sbsociologia.com.br/portal/index.php?option=com> . Acesso em: 14 dez. 2013.

MAB. Movimento dos Atingidos por Barragem. Água e energia, não são mercadorias! Disponível em: <www.mabnacional.org.br/noticia/reivindica-es-imediatas-dos-atingidos-pelausina-santo-ant-nio> Acesso em: 4 jan.2014.

MMC. Movimento das Mulheres Camponesas, link: Lutas. Página inicial da organização. Disponível em: <www.mmcbrasil.com.br/site/node/47>. Acesso em: 26 dez. 2013.

MESSA, Márcia Rejane. Os Estudos feministas de Mídia: uma trajetória anglo-americana. 2006. Disponível em: <www.pucrs.br/famecos/pos/cartografias/artigos/marcia_messa.pdf> Acesso em: 4 jan. 2014.

MOURÃO, Patrícia. Organização produtivas de Mulheres Rurais. Disponível em: <http://www.iica.int/Esp/regiones/sur/brasil/Lists/DocumentosTecnicosAbertos/Attachments/39 0/Artigo\%20\%20Organiza\%C3\%A7\%C3\%A3o\%20produtiva\%20de\%20mulheres\%20rurais\%2 0-\%20Patr\%C3\%ADcia\%20Mour\%C3\%A3o\%20-\%20NEAD.pdf>. Acesso em: 10 jan. 2014. 
RONDONIA Dinâmica. Ações do Incra apoiam mulheres do campo em Rondônia. Publicada em 07 março, 2012, 12h32min. Jeanne Machado, Jornalista Responsável. Disponível em: <http://www.rondoniadinamica.com/arquivo/acoes-do-incra-apoiam-mulheres-do-campoem-rondonia,33260.shtml> . Acesso em: 26 jan. 2014.

SAE. Santo Antônio Energia. Disponível em: <www.santoantonioenergia..com.br>. Acesso em 03 jan. 2014.

VIA Campesina. A voz do camponês internacional. Pagina inicial da organização. Detalhes publicados em quarta feira, 09 fevereiro, 2011 14:08. Disponível em: <http:/viacampesina.org/em/index.php/organisation-mainmenu-44>. Acesso em: 27 dez. 2013.

VICENTE, Ana. Os Poderes das Mulheres, Os Poderes dos Homens (1998). Disponível em: $<$ http://www.edtl.com.pt/index.php?option=com_mtree\&link_id=1040:estudos-sobre-asmulheres\&task=viewlink> Acesso em: 28 ago. 2014. 


\title{
A festa do divino espírito santo em Pimenteiras e a cobertura das novas mídias digitais: o caso dos blogs de Rondônia
}

\author{
Lilian Maria Moser (UNIR) \\ José Willians Simplicio da Silva (UNIR)
}

\section{Introdução}

O capítulo objetiva problematizar algumas nuances da festa do Divino Espírito Santo sob o prisma dos Estudos Culturais. Cabe ponderar, contudo, que se trata aqui duma incursão ainda preliminar, na qual buscamos discutir, levantar questões sobre a cobertura/e/ou informações produzidas e veiculadas pelas mídias digitais (blogs). Ao analisar as mídias e esta em particular, pelo viés dos estudos culturais, verifica-se um importante entendimento da relação entre cultura e cibercultura.

Segundo consta na bibliografia que versa a respeito da temática ${ }^{1}$, a referida festa teve início no Século XIX, para atender aos anseios religiosos das populações locais, com a finalidade de manter acesa a chama da fé dos integrantes daquelas comunidades que, possivelmente, o fizeram para dar vazão aos anseios da espiritualidade. Com passar do tempo, e dinamicidade comum às manifestações culturais populares, essa ocorrência histórico-religiosa transformou-se numa das mais expressivas referências de manifestação do chamado patrimônio imaterial do Estado de Rondônia.

O intuito da presente discussão é mostrar como esse evento tem sido apresentado sob a ótica midiática, visto que esse bem cultural configura-se em um símbolo sagrado de devoção pelos moradores das comunidades quilombolas de Pimenteiras e circunvizinhanças; e em concomitância, investigar a maneira segundo a qual as festividades de cunho espiritual, rememoram, constroem e dão sentidos outros às sociabilidades vivenciadas no passado e ritualizadas no presente.

Entendemos assim, que a simbologia apresentada e representada quando às pessoas realizam cultos religiosos diversos, como celebrações, novenas, romarias, fitas-votivas, promessas, dentre outras demonstrações de devoções, não são ricas apenas pelo ritual que encerram; mas também pela historicidade que expressam, nos motivos de ser que englobam, no componente de registro e informações a respeito do passado que esses atos apresentam, mesmo depois de tantas transformações operadas em seus sentidos e formas de apresentação, cuja própria existência e continuidade são o exemplo mais notável de que sua polissemia abarca experiências vividas e vivências contemporâneas.

As manifestações da simbologia do evento despertam o interesse dos meios midiáticos em produzir e veicular informações das pessoas envolvidas no culto religioso ao

\footnotetext{
${ }^{1}$ São poucos os trabalhos até agora publicados concernentes a Festa do Divino Espírito Santo do Guaporé, nas fronteiras entre Brasil e Bolívia. Para se ter acesso a discussões, sobretudo no que diz respeito a constituição desse bem cultural na região, consultar HARRISON (2008).
} 
Divino Espírito Santo. Isto significa dizer que se pretende com esse trabalho, olhar para a Festa do Divino a partir de uma visão sistêmica, e não vê-la, apenas, como Patrimônio cultural imaterial ou, simplesmente, como símbolo de poder político administrativo e espiritual da Igreja Católica. Mas, sobretudo, verificar como essas e outras questões são galgadas sob a perspectiva das mídias digitais.

Feitas estas ponderações, é válido destacar que não se deve descuidar do fato dessas serem manifestações culturais de caráter religioso e, como tal, compõe parte das expressões da cultura popular realizadas pelos habitantes das comunidades ribeirinhas tradicionais de Pimenteiras. Reiterar essa questão é importante para não se descuidar da importância e necessidade de procurar compreender as representações do povo sobre o Divino, como um "ser capaz de curar" suas doenças do corpo e do espírito. Qual seja, existem eventos ali de outra ordem, que se rementem a dimensões que o pesquisador nem sempre consegue adentrar em sua investigação.

Ainda assim, discussões nesse campo das religiosidades, das crenças são fundamentais no sentido de compreender não somente como se estruturam as relações sociais, as negociações, os conflitos, a construção de identidades dentro da chamada cibercultura.

Ao adentrar em discussões como essas, polissêmicas que são, em todos os sentidos possíveis, um arsenal de questões relevantes é posto em cena, pois oportuniza ao leitor um conhecimento histórico sobre as dimensões de poder exercidas pelas mídias, que vão além do âmbito religioso, comumente, privilegiado pela história, descaracterizando outras variáveis sobre o evento.

Parte das reflexões aqui desenvolvidas ancorou-se na bibliografia e historiografia locais - as quais conforme já ponderamos são ainda bastante sucintas, que abordam a história da Festa do Divino, e por referencial teórico, tomamos, sobretudo, as discussões desencadeadas por: Bruno Nogueira, "Por uma função jornalística nos blogs de MP3- Download e crítica ressinificados na cadeia produtiva da música (2011)"; André Lemos, "Cibercultura: alguns pontos para entender a cultura de nossa época (2011)" Mircea Eliade, "O sagrado e o profano: A essência das religiões (1992)"; Zygmunt Bauman, "Modernidade Líquida (2007)"; e Pierre Bourdieu, "Cultura e Política (1980)".

$\mathrm{O}$ texto encontra-se organizado em três seções, além desta. Na próxima seção, busca-se conhecer a relação entre a festa do Divino Espírito Santo e a imprensa digital, enfatizando também o importante papel desencadeado pela internet na cobertura da festa. A terceira seção, dedica-se à análise de textos produzidos e as informações noticiadas pelos blogs locais sobre a festa do Divino, demonstrando as lacunas nos textos publicados. Na última sessão serão discutidas as condições de produções midiáticas, despertando o leitor para observar como são mediadas as informações pelas mídias digitais.

\section{A representação da festa do divino pela mídia}

De acordo com as oralidades dos devotos ${ }^{2}$ do Divino Espírito Santo, devido ao grande número de pessoas que participam do evento ter aumentado de forma significativa a cada ano, esse fato fez a imprensa despertar interesse na festa. Da festa do Divino participam o clero,

\footnotetext{
${ }^{2}$ Relatos dos registros orais extraídos do Presidente da "Irmandade do Divino Espírito Santo" apresentado pela pesquisadora Liana Ferraz Bedôr Jardim (2011), na sua dissertação de mestrado, cujo tema é "A fala da mulher: identificação dos aspectos linguísticos e o papel da Mulher quilombola do Vale do Guaporé através de sua fala".
} 
fiéis, romeiros, turistas, mídia, curiosos e políticos ${ }^{3}$. Ela constitui-se um evento cultural de mistura de cores, crenças e ritos. Não esquecendo que dentro desse espaço sagrado, o profano ${ }^{4}$ se mostra cotidianamente em diversos momentos dos festejos.

Nesse entendimento, a mídia digital tem dado importância ao evento atuando como um dos veículos de comunicação, divulgação e representação da Festa do Divino Espírito Santo, uma das festas religiosas locais mais expressivas da cultura local.

A imprensa digital tem mostrado nas suas produções, o histórico da festa do Divino, por meio de textos e imagens fotográficas, inclusive ações que motivam as pessoas a realizarem e fazerem parte do acontecimento. Dessa forma, percebe-se o papel importante que a internet tem desempenhado para pulverização do evento junta à sociedade.

Aqui, buscaremos conhecer a relação entre a Festa do Divino e a imprensa, a fim de entender melhor as informações "vulgarizadas" pela mídia digital $(b \log )^{5}$ sobre o evento para os internautas.

Conforme alguns blogs pesquisados, usa-se a hipótese de que a mídia tem influenciado bastante na festa do Divino Espírito Santo, obviamente não podemos menosprezar o relevante papel que tem a divulgação através da comunicação oral. Nesse rol de discussão, é relevante destacar que as informações passadas em conversas entre pessoas, representa um meio importante de veiculação do conhecimento sobre a festa acima mencionada. Principalmente nas comunidades onde a informação midiática ainda não construiu espaços.

A cobertura da Festa do Divino no vale do Guaporé tem crescido bastante na internet, por isso esta parte do trabalho focou a análise no blog G1, este que faz parte de um dos maiores canais de comunicação do país. Foi necessário fazer um recorte temporal, devido às diversas matérias publicadas sobre a festa. Optou-se pela matéria do dia 03 de junho de 2012, cuja edição traz o título: "Festa do Divino de Rondônia pode ser registrada como patrimônio da União"

\footnotetext{
${ }^{3} \mathrm{Na}$ coletividade da vida religiosa vive-se a individualidade, quer dizer, as pessoas manifestam culturalmente os ritos religiosos e crenças no que acreditam ser divino, mas dentro dessa dinâmica tem necessidades específicas. Como também não são iguais para todos os motivos de estarem presentes no evento. Para aprofundar-se na discussão, consultar Émile Durkheim (2000), no livro "As formas elementares da vida religiosa".

${ }^{4}$ De acordo com Mircea Eliade, em o Sagrado e Profano (1992), durante a vida terrena o homem vive ao mesmo tempo uma vida sagrada e profana. No caso da festa do Divino Espirito Santo os momentos profanos podem ser evidenciados quando nos intervalos das manifestações religiosas (ritos e crenças), acontecem os festejos sociais (bailes, danças e consumo de bebidas alcoólicas). Seguindo essa linha de raciocínio, fator importante dessas práticas religiosas que acontece no "espaço sagrado" em referência o Divino, conforme acentua Mircea Eliade (1992), é a noção de tempo, pois a cada manifestação religiosa que acontece ao longo das procissões fluviais e nas casas dos quilombolas, ao longo das margens do Guaporé, significam bem mais que apenas uma manifestação, um acontecimento de cunho sagrado. Seus ritos, as sociabilidades ali vivenciadas, constituem-se também em momentos nos quais o chamado mundo "profano" e seus anseios marcam presença.

${ }^{5}$ Baseado em Bruno Nogueira (2011), os Blogs (diário online), foram criados para produção de informações textuais. Hoje em dia esse tipo de ferramenta da internet abrange outros tipos de categorias, como imagens, músicas e vídeos. Ainda de acordo com o pesquisador acima, essa plataforma, facilita o acesso a notícias diversas, e dispõe de conteúdo organizado em forma cronológica através de categorias e tags.
} 
Figura 1 - imagens da edição de 03 de junho de 2012 do G1 dando destaque à festa do Divino Espírito Santo como patrimônio da cultura imaterial da União

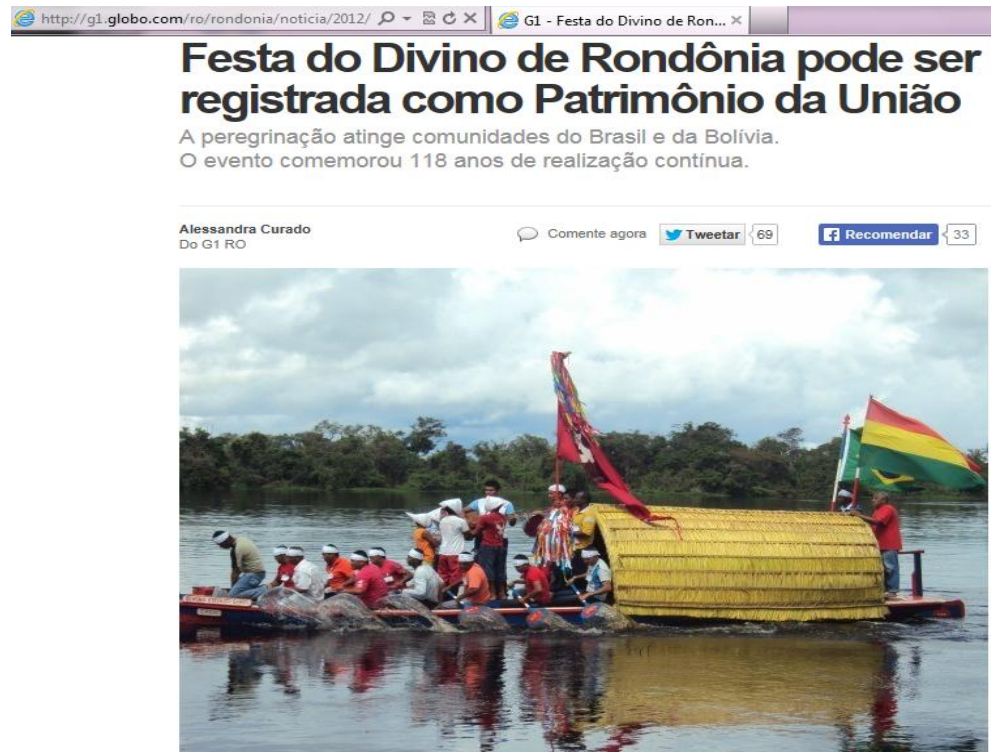

Fonte: http://g1.globo.com/ro. Acesso em: 03 Fev. 2014.

Analisando a íntegra dessa matéria veiculada pelo blog do G1, percebe-se que o Divino ganhou destaque na mídia digital nacional. Ao longo do texto produzido pelo Blog, com o adensamento das discussões, o sentido mercadológico, ou a perspectiva da "comercialização da cultura" se torna mais evidente, na medida em que a festa sacra do Divino incorpora e é incorporada aos efeitos da chamada Globalização, demonstrando, portanto, uma identidade local que ao mesmo tempo em que é dita "fragilizada" e "ameaçada" pelos valores materialistas do capitalismo, nos quais a noção de patrimônio cultural é feita, em larga medida, para atender e impulsionar a recente indústria do turismo religioso; esta também se utiliza de linguagens e estratégias da globalização para divulgar-se, para ser conhecida, para se dizer e fazer-se patrimônio nacional.

Logo, destaca-se que o blog enquanto mídia digital pode ser considerada como uma valiosa fonte histórica de pesquisa para o estudo em discussão. Em consonância com Bruno Nogueira (2011), afirmamos que a produção de um blog ou qualquer outro tipo de mídia, tem um sentido de ser criado e um público a ser atingido. Assim sendo, a sua sobrevivência depende daqueles que consumirem ${ }^{6}$ a informação veiculada. Nesse entendimento, salienta Adorno (2002) que a ética dos meios de comunicação de massa é com dados estatísticos "audiência do público", e não com a qualidade do produto ofertado.

Dessa forma, são as informações levadas pelas mídias às massas que têm o poder de influenciar a opinião pública, ou seja, ela tem o poder de seduzir as pessoas para criar verdades entendidas ou apresentadas como absolutas e encobrir outras possibilidades. Entretanto, mesmo a mídia não sendo na sua ampla acepção terminológica "democrática”, não se pode considerar a sociedade como sendo simplória vítima das mídias (existem pessoas que sabem absorver e selecionar as informações divulgadas). No caso da mídia digital (blogs), geralmente existe a possibilidade de crítica e interação com a informação veiculada, pois o internauta é convidado a deixar suas impressões sobre a informação divulgada, ou seja, o leitor é visto como ser ativo que

\footnotetext{
${ }^{6} \mathrm{~A}$ respeito da discussão sobre indústria cultural, um interessante trabalho é desencadeado consultar Adorno (2002), na obra "Indústria Cultural e Sociedade".
} 
recebe, lê e produz informação. Todavia, quando considerada a proporção das pessoas que acessam essas mídias, ainda são poucos os que se arriscam a fazer ponderações e comentários relevantes à produção veiculada pelos blogs.

Por isso, faz-se necessário verificar sistematicamente essas ocorrências, pois sempre existem interesses de quem pulveriza essas matérias para sociedade. É importante ressaltar que quando as mídias criam e legitimam verdades, elas fazem isso com o aval dos leitores, ou seja, as mídias vulgarizam os ditames para sociedade (relações sociais), porém quem legitima e dá sentido as verdades é o "povo". Assim sendo, cabe aos meios midiáticos apoderar-se desse leque de possibilidades, para conquistar o seu espaço nas manifestações culturais.

\section{Festa do divino na mídia - o caso dos blogs Rondônia}

A festa do Divino Espírito Santo realizada no vale do Guaporé pelos povos quilombolas mobiliza pessoas de várias partes de Rondônia, estados circunvizinhos e da Bolívia. O evento consiste em uma manifestação cultural de caráter religioso, feita pelos populares e devotos que fazem do Divino um símbolo de devoção popular.

Historicamente, a Festa do Divino está associada às tradições religiosas portuguesas do Século XIV. Nesse prisma, a festa representa uma ocorrência importante para a história dos povos quilombolas da "Amazônia", pois na sua concepção, essas manifestações culturais são feitas para demonstrar atos de sociabilidade religiosa. É importante destacar que a festa tem atraído também os olhares dos rondonienses.

O fato da mídia "vulgarizar" a festa do Divino Espírito Santo para sociedade, a partir de matérias veiculadas nos blogs locais, dentre outros canais de informação, têm demonstrado o quanto a imprensa pode ser uma ferramenta utilizada em "tempos de era digital", em favor de um evento cultural importantíssimo para a representação da cultura religiosa local.

É relevante informar que o culto religioso ao Divino Espírito Santo, não mantém nenhum tipo de mídia digital para difundir o evento. Conforme indicam os relatos orais das pessoas vinculadas às comunidades que realizam os ritos veem se repetindo de geração a geração, pois os pais, num esforço de manter as tradições culturais da comunidade, ensinam os filhos a crença no Divino e repassam o compromisso de manter as festividades religiosas consuetudinárias. Essas atitudes revelam que embora façam parte de um mundo globalizado, possivelmente o desejo e luta dessas populações seja o de manter a tradição dos festejos, sem a preocupação de expansão ou comercialização da cultura, ou seja, o interesse de preservar a cultura imaterial da tradição local.

A partir de interesses "exógenos", a mídia local passou a dar espaço para festa do Divino Espírito Santo, produzindo informações sobre essa manifestação religiosa da cultura local. No entanto, sabemos que ao confeccionar uma matéria para ser divulgada pela imprensa, a mesma vem sempre acompanhada de uma "intenção", mesmo assim essas matérias afirmam o espaço dado à festa pela mídia. Por essa ótica, salientamos que a informação sempre fomenta algum tipo de mobilização.

Um dos primeiros blogs a divulgar e festa do Divino Espírito Santo, foi o blog Divino do Guaporé. As primeiras matérias noticiadas cronologicamente pelo blog são datadas de 2008. A sua página na internet pode ser acessada no seguinte endereço eletrônico: http://divinodoguapore.blogspot.com.br/. A importância deste webblog reside no fato de fornecer ao internauta, devoto ou não do Divino Espírito Santo, a oportunidade de estreitar uma relação de proximidade. Essa relação encurta-se quando, por exemplo, um fiel do Divino 
rememora no ciberespaço aquilo que vivenciou durante a festa do Divino Espírito Santo, por meio da apresentação de imagens, reportagens, vídeos e produção textual. Tendo em vista que a cada ano são arquivadas novas fotos e novas matérias que revelam para o devoto os momentos religiosos dos festejos.

Figura 2 - imagens da edição do dia 30 de maio de 2013 do Divino do Guaporé destacando os momentos sacros ao Divino Espírito Santo

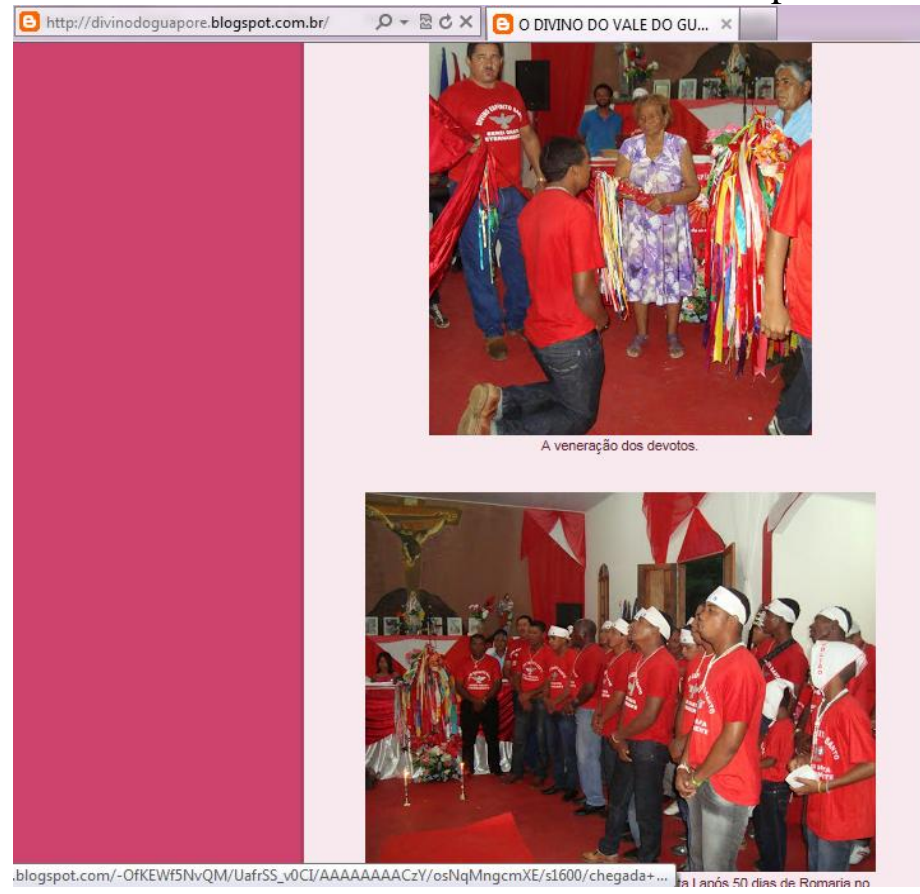

Fonte: http://divinodoguapore.blogspot.com.br. Acesso em: 03 Fev. 2014.

Segundo Peter Burke (1992), a partir dos historiadores dos Annales, a história trouxe em seu arcabouço novos métodos, novas fontes, novas abordagens e novos temas. Dessa forma, ao acessar as produções dos blogs locais, foi importante para aprofundar os conhecimentos sobre esse fenômeno religioso. Tendo em vista que o acesso a outros tipos de fontes históricas, como por exemplo, materiais impressos são de difícil acesso.

Entretanto, ao problematizar algumas matérias noticiadas pelos blogs locais com o sentido de fazê-la falar, constatamos que alguns blogs, como por exemplo, o Portal do Divino, enaltecem a figura da Igreja Católica, quando na verdade historicizando esse fenômeno religioso, evidenciamos que a festa do Divino teve início com os povos quilombolas do Guaporé.

Importa também fazer um contraponto sobre essa questão dos blogs enaltecerem a Igreja Católica, porque essa instituição religiosa foi durante muito tempo parte combatente do Catolicismo Popular. Entende-se por "religiosidade popular"7, uma mistura cultural entre os

\footnotetext{
${ }^{7}$ É sabido que o processo de "romanização" da igreja católica no Brasil foi bastante moroso, o que acabou por dar origem a uma espécie de catolicismo que em larga medida, incorporava elementos da cultura que se desenvolvia naquela espacialidade e que eram "alheios" as orientações de Roma. Na busca da Igreja Católica, para diferenciar essas manifestações do catolicismo dito "oficial" ou "legítimo", criou-se a expressão "catolicismo popular", a qual, não por acaso, revela uma relação de alteridade, uma forma conceber, ver e dizer o outro bastante significativa. Ao tratar de "religiosidade popular" não intencionamos aqui, reproduzir essa bifurcação baseada na dicotomia "falso" versus "verdadeiro" Aliás, esta é uma questão que buscaremos problematizar no decorrer da pesquisa, no sentido de revelar as relações de poder que ela incorpora Contudo, por este se constituir numa espécie de "artigo síntese" do tema, utilizaremos as nomenclaturas que geralmente são mais correntes na discussão da temática.
} 
ritos da Igreja com as práticas de sentido indígena e as manifestações afro-brasileiras. Isso remete à noção de que a religiosidade popular é um emaranhado de múltiplas facetas expressadas culturalmente de várias formas.

É importante esclarecer que a Igreja Católica possui direcionamentos bem definidos, inclusive em concílios, no que concerne aos rituais a serem observados na religião, se configurando como um dos papéis da instituição, zelar pelas premissas do chamado "catolicismo romano".

Dessa maneira, foi, e ainda é, prática corrente na instituição buscar obter o controle dos seus fiéis, ou antes, orientá-los, no sentido de observarem e obedecerem às orientações de Roma.

Notamos ainda que as matérias veiculadas pelo portal do divino tem dado destaque às autoridades políticas e religiosas, marginalizando os nomes das pessoas comuns que se esforçam durante o ano inteiro para organizar o evento. De certo ângulo, essa ocorrência descaracteriza o papel dos atores sociais engajados na construção da festa. Destarte, não podemos marginalizar vozes que foram e são importantes para a construção dos festejos ao senhor Divino, ou seja, na perspectiva da história cultural, a cultura das pessoas comuns deve ser trazida para o foco do debate no sentido de valorizar essas expressões culturais.

Verificamos também que alguns blogs pesquisados divergem em relação ao tempo de duração da festa do Divino Espírito Santo, uns informam que o evento dura quarenta dias, já outros falam em cinquenta. Para o internauta, devoto ou não, fica a imprecisão do recorte temporal da festa.

Visualizamos ainda que alguns blogs parecem fomentar essas manifestações como objeto de exploração para o turismo, na chamada comercialização da cultura. Atitudes como essas acabam por valorizar mais a "coisa" em detrimento dos sujeitos que a constroem e a dão sentido. Em palavras outras, valoriza-se o potencial turístico de determinado bem pelo retorno econômico que pode trazer, em detrimento do que ele significa efetivamente para os homens e mulheres que os ritualizam, e para sua comunidade de referência. Este é certamente efeito da Globalização tão lembrada por Stuart Hall, já que muitas pessoas veem a Festa como possibilidade de auferir ganhos econômicos, com a venda de produtos que vão de artigos religiosos a passeios turísticos.

Quando a cultura é tornada objeto, ressalta Meneses (2006), visando atender basicamente as demandas de ordem econômica, o processo de fruição, tão necessário à prática do turismo quanto à interpretação de culturas, acaba não se efetivando e as manifestações culturais se veem reduzidas nessa lógica de mercado, a condição de mercadoria.

Assim sendo, compreendemos que estes tipos de informações veiculadas pela mídia digital local, podem ser dissecadas pelo internauta, com a finalidade de contribuir com as produções existentes sobre o evento.

\section{A informação mediada pela mídia digital}

Segundo Pierre Bourdieu (1980), o texto midiático seja no jornal, revista ou rádio, possui várias vertentes ideológicas sobre a melhor forma de influenciar o seu público com o "produto ofertado". Vale salientar também que na atual conjuntura midiática a internet têm se destacado cada vez mais entre os meios de comunicação. Muitos desses canais de informação são empresas e sobrevivem da publicação de notícias, por meio da técnica de convencimento. 
Por isso, é interessante identificar a linha de trabalho e os responsáveis pela edição da matéria veiculada pela mídia.

Ainda de acordo com Bourdieu (1980), e trazendo para a perspectiva da discussão, faz-se necessário entender como são produzidas as matérias sobre a festa do Divino Espírito Santo pulverizada na mídia. Este conhecimento é importante, pois ajuda a compreender as condições da produção e do produto. Para Pierre Bourdieu, a veiculação da informação pela imprensa merece análise profícua, numa expressão do autor "é preciso entrar na cozinha da produção".

Por meio da simulação ou interação nas mídias digitais, o internauta tem a oportunidade online de vivenciar aquilo que não foi possível fisicamente ${ }^{8}$. Inclusive interagindo as produções através de fotos e textos contidos nos $b \log s$, que veiculam notícias sobre a festa do Divino Espírito Santo. Dessa maneira, a Globalização cria novos tipos de sociabilidades a partir da cibercultura ${ }^{9}$. Assim, a cibercultura encurta espaços que antes eram distantes, permitindo a ampliação das formas de comunicação e ação do "homem" sobre o mundo por meio das mídias digitais.

Nessa linha de pensamento, as pessoas que buscam se informar sobre as manifestações expressões culturais locais apoderando-se da cibercultura. Conforme André Lemos, afirmamos "a cibercultura representa a cultura contemporânea sendo consequência direta da evolução da cultura técnica moderna" (LEMOS, 2011, p. 3). Ainda seguindo essa ótica de discussão, a mídia oportuniza ao leitor internauta conhecimento sobre fatos que ele não testemunhou, ou se testemunhou, sente a necessidade de rememorar a ocorrência.

Em se tratando da mediação dos meios de comunicação, é preciso atentar o que é noticiado, já que não se pode estar em todo lugar ao mesmo tempo nem ter a exata dimensão da diversidade de pontos de vistas dos sujeitos que constroem e conferem sentido a tal manifestação. No caso da festa do Divino Espírito Santo, isto quer dizer que não se pode testemunhar fielmente o que aconteceu durante os dias de festejos. Com isso, a mídia em muitas ocasiões, se encarrega de filtrar leituras, pontos de vistas e divulgar aquilo que ela acha conveniente ou pertinente, uma vez que a partir do poder da técnica de convencimento, a indústria cultural cria condições favoráveis à circulação da informação.

Quando os leitores internautas acessam os webblogs que tratam da festa do Divino Espírito Santo, como já mencionado acima, eles podem interagir com a informação divulgada através da postagem de comentários. Com esse raciocínio Bruno Nogueira afirma que "a partir dos blogs, uma parte do público que até então era apenas consumidor passivo, passa a fazer suas próprias críticas e resenhas de produtos em diários pessoais" (NOGUEIRA, 2011, p. 141). Isso é interessante porque no caso dos jornais impressos, a construção de matérias veiculadas não é possível. Essa forma de produção Pierre Bourdieu (1980) chama de produto acabado: “O produto acabado, a opus operatum, esconde o modus operandi" (BOURDIEU, 1980, p. 1). Ou seja, é um produto pronto que não fornece espaço para construção ou desconstrução da

\footnotetext{
${ }^{8}$ Vale salientar, que embora seja possível aproximar-se do Divino através das mídias digitais, o contato com o Divino materializado em forma de uma pomba não é o mesmo. A relação é de mentalidades. Para aprofundar-se na discussão de formas de produção e recepção, consultar o estudioso Roger Chartier apud Carvalho (2005), no trabalho "o conceito de representações coletivas segundo Roger Chartier".

${ }^{9}$ Baseado no trabalho de André Lemos "Cibercultura: alguns pontos para entender a cultura de nossa época" (2011), cibercultura significa novas tecnologias de informação e comunicação. Ainda de acordo com o autor acima a cibercultura é formada por novas práticas comunicacionais no ciberespaço, como por exemplo, e-mails, weblogs, mídias digitais.
} 
informação mediada. Logo desconsiderando assim a opinião das pessoas, vozes essas, que têm relevância para construir uma matéria veiculada pela imprensa. Mesmo que saibamos que, nem sempre quem escreve está disposto a ouvir o que as pessoas têm a falar.

Considerando a importância de refletir o tema, recorremos aos estudos de Adorno (2002), para quem nem todas as pessoas conseguem fazer crítica cultural sobre o que está sendo informado pela mídia. Pois, a técnica usada para noticiar é um mecanismo de sedução poderoso que nem sempre é possível dissecar o que está escrito. Vale destacar, que esse público é principalmente aquele que a mídia busca atingir, uma vez que os questionamentos são insignificantes.

Nessa conjuntura de discussões, balizados em alguns estudiosos, afirmamos que as matérias não significam a totalidade do que se passa dentro e fora da Festa do Divino Espírito Santo, muitas informações possivelmente são marginalizadas, quer dizer, muitas ocorrências são silenciadas em detrimento de outras que a mídia considera importante.

Recorrendo mais uma vez a Pierre Bourdieu (1980), compreendemos que a análise da mídia deve ser feita com um olhar sistêmico, que possibilite ao interessado no assunto verificar outras informações sobre a ocorrência noticiada. $\mathrm{O}$ autor ainda lembra que o alcance dos meios de comunicação é construir influência a médio e longo prazo, visto que o seu interesse é conquistar um público assíduo e alienado (ser inativo) ao que perpassa à frente.

Para Bourdieu (1980), as relações de comunicação são sempre relações que emanam poder. Em diálogo com a perspectiva exposta por Bourdieu, o teórico Carvalho apud Roger Chartier (2005) nos mostra que os "sistemas simbólicos" têm sempre a função política de criar e legitimar dominações sociais de uma classe sobre as outras. Vale salientar, que existem formas de violência simbólica nos mais diversos campos da vida social, inclusive, no que concerne ao plano intelectual.

Mediante as questões elencadas ora no debate, ao povo até certo ponto, cabe participar da produção das informações, visto que o leitor ${ }^{10}$ tem a oportunidade dentro do ciberespaço de responder as mídias, por meio da criação de textos nos próprios blogs. Portanto, a mídia torna-se um espaço militante, onde muitas vezes a opinião pessoal supera a informação noticiada/editada pelo blog. Pode-se inclusive criar blogs onde a informação sobre as atividades de manifestação cultural é feita pela pessoa comum, ou seja, o público passa a produzir e consumir o seu próprio conteúdo. Com isso, emprega-se um capital cultural que vem da sociedade. Nessa concepção, o leitor virtual não é um ser estático e sim um ser ativo. Entretanto, Maria Regina Baracuhy (2010), lembra que a mídia é uma das maiores produtoras de identidades para os atores sociais.

Corroborando com o debate sobre a construção de identidades o polonês Zymunt Bauman (2007) afirma que a identidade na condição de vida contemporânea é liquida, quer dizer, ela vive em constante transformação. Mediante as questões levantadas pelo estudioso observamos que a lógica vivida na chamada modernidade tardia é a de que a identidade se caracteriza por ser móvel e transitória. Nessa direção, consideramos que o efeito da chamada Globalização é devastador, além de banalizar as relações humanas, constrói relações de

\footnotetext{
${ }^{10}$ Reforçamos ideia de que não somente as vozes sagradas podem se apoderar da cibercultura para deixar suas impressões sobre as informações veiculadas pela mídia. Nessa lacuna aberta as vozes profanas certamente podem expressar sua opinião, mesmo em se tratando das ocorrências de cunho sagradas. Acrescenta Pelisoli (2003, p.4) apud Bruno Nogueira (2011) que no hiperespaço, ele ganhou ferramentas - mouse, teclado, canetas ópticas, fones de ouvido e microfones, uma série de extensões dos seus sentidos que permitem responder de várias formas ao que ele ouve, vê, lê, e mesmo toca - por que não?
} 
identidades cada vez mais artificiais, pois em tempos de modernidade, ela dita as regras da vida que o indivíduo leva socialmente. Para tanto, cria uma indústria de identidades de correntes perenes e nessa correnteza veloz da vida moderna, não existe "pausa" para solidez, parafraseando Bauman (2007), ela constitui-se como modernidade liquida.

\section{Considerações finais}

A festa do Divino Espírito Santo celebrada do vale do Guaporé constitui-se como uma das mais expressivas manifestações da cultura religiosa de Rondônia. Nesse sentido, e também pela exploração midiática do evento, é relevante realizar uma pesquisa mais profícua desta relação. Este trabalho visou trazer para o foco da discussão a influência que os recursos da mídia digital local por meio dos blogs locais pode ter na cultura expressada na festa do Divino.

Para tanto, foram feitas leituras dos blogs em outras publicações que trataram da festa do Divino. Nestas, percebemos que o evento tem sido evidenciado nos espaços de cibercultura, demonstrando, portanto, a relevância do tema e o interesse que os meios de comunicação têm em divulgar a festa para a sociedade.

Após a análise realizada nas produções de blogs referentes à festa do Divino Espírito Santo, constatou-se que as matérias permitem diferentes apreciações por parte dos leitores, para fazer intervenções no sentido de construir os textos em abertos. Para tanto, podendo dessa forma se posicionar contra ou a favor das informações pulverizadas.

Mediante às observações que temos realizado, ainda que preliminares, entendemos que a diversidade de questões e a importância que a discussão ora travada fomenta, não deve ficar restrita apenas à academia, mas provocar o bom debate, sobre como estão sendo construídas novas relações de sociabilidade por meio da informação mediada pela mídia digital.

\section{Referências}

ADORNO, Theodor. Indústria Cultural e Sociedade. [Tradução Juba Elisabeth Levy]. São Paulo: Paz e Terra, 2002.

BAUMAN, Zygmunt. Modernidade Líquida. [Tradução Carlos Alberto Medeiros]. Rio de Janeiro: Jorge Zahar, 2007.

BURKE, Peter (org). A escrita da história: novas perspectivas. São Paulo: UNESP, 1992.

BOURDIEU, Pierre. Cultura e Política. Comunicação feita na Universidade de Grenoble em 29 de abril de $1980 . \quad$ Disponível <http://www.armario.cl/2dat/3Apuntes/1Autores/Bourdieu/Pierre\%20Bourdieu\%20$\% 20$ Cultura\%20e\%20PolItica.pdf>. Acesso em: 29 Jan. 2014.

CARVALHO, Francismar Alex Lopes. O conceito de representações coletivas segundo Roger Chartier. Diálogos, DHI/PPH/UEM, v.9, n.1, p. 143-165-165, 2005. Disponível em: <www.sc.senac.br/biblioteca/.../CHARTIER\%20E\%20BORDIEU.pdf>. Acesso em: 03 Fev. 2014.

DURKHEIM, Émile. As formas elementares da vida religiosa. [Tradução Paulo Neves]. São Paulo: Martins Fontes, 2000. 
ELIADE, Mircea. O sagrado e o profano: A essência das religiões. [Tradução Rogério Fernandes]. São Paulo: Martins Fontes, 1992.

Festa do Divino de Rondônia pode ser registrada como patrimônio da União. Disponível em: <http://g1.globo.com/ro/rondonia/noticia/2012/06/festa-do-divino-de-rondonia-pode-serregistrada-como-patrimonio-da-uniao.html>. Acesso em: 03 Fev. 2014.

Festa do Divino em Rondônia - Brasil. Disponível em: <http://www.portaldodivino.com/nobrasil/vale.htm>. Acesso em: 03 Fev. 2014.

Festa do Senhor Divino Espírito Santo em Pimenteiras do Oeste. Disponível em: $<$ http://rondoniatualidades.com.br/rondonia/festa-do-divino-espirito-santo-no-vale-doguapore/>. Acesso em: 03 Fev. 2014.

HARRISON, Alexandre Thomaz. A metamorfose do sagrado - O legado africano no cotidiano religioso dos vales do Guaporé e Mamoré. Saber Científico, Porto Velho, 1 (2): 1 - 18, jul./dez.,2008.

HALL, Stuart. A identidade cultural na Pós-Modernidade. Rio de Janeiro: DP\&A, 2002.

JARDIM, Liana Ferraz Bedôr. A fala da mulher: identificação dos aspectos linguíísticos e o papel da Mulher quilombola do Vale do Guaporé através de sua fala / Liana Ferraz Bedôr Jardim. [manuscrito] - 2011. 207 f. Dissertação (mestrado) - Universidade Federal de Rondônia: Guajará-Mirim, 2011.

LEMOS, André. Cibercultura: alguns pontos para entender a cultura de nossa época. Publicidade Digital e Mídias Sociais, 2011. Disponível em: <www.duguay.com.br/docs/pupdigital_03_aps.pdf>. Acesso em: 29 Jan. 2014.

MENESES, José Newton Coelho. História e Turismo cultural. Belo Horizonte: Autêntica, 2006.

NOGUEIRA, Bruno. Por uma função jornalísticas nos blogs de MP3- Download e crítica ressinificados na cadeia produtiva da música. 2011. Disponível em: $<$ https://www.google.com.br/\#q=NOGUEIRA\%2C+Bruno.+Por+uma+fun\%C3\%A7\%C3\%A3o +jornal\%C3\%ADsticas+nos+blogs+de+MP3wnload+e+cr\%C3\%ADtica+ressinificados+na+cad eia+produtiva+da+m\%C3\%BAsica>. Acesso em: 03 de Fev. 2014.

Os Festejos do Divino de Pedras Negras 2013. Disponível em: <http://divinodoguapore.blogspot.com.br/>. Acesso em: 03 Fev. 2014.

PIEDRAS, Elisa Reinhardt. A contribuição dos estudos culturais para abordagem da publicidade: processos de comunicação persuasiva e as noções "articulação" e "fluxo". Revista da Associação de Nacional dos Programas de Pós-Graduação em Comunicação, 2006. Disponível em: <www.compos.org.br/seer/index.php/e-compos/article/viewFile/74/74>. Acesso em: 03 Fev. 2014.

TEIXEIRA, Marco Antônio Domingues; FONSECA, Dante Ribeiro da - Histórico das comunidades de remanescentes de quilombo de Pedras Negras, Santa Fé, Forte Príncipe da Beira - Vale do Guaporé - Rondônia. Disponível em: <http://www.gepiaa.unir.br/index.php/123/article/viewFile/14/>. Acesso em: 28 Jul. 2013. 
Vale do Guaporé: a Festa do Divino começa em Costa Marques. Disponível em: <http://www.pakaas.net/di1.htm>. Acesso em: 03 Fev. 2014. 


\title{
A influência das mídias e o poder simbólico das redes sociais no facebook na divulgação de eventos religiosos pentecostais e das religiões de matrizes africanas em Porto Velho ${ }^{1}$
}

\author{
Joel Balduino da Silva Junior(UNIR) \\ Miguel Nenevé (UNIR)
}

\section{Introdução}

Observamos em nosso cotidiano a divulgação de eventos, imagens e reportagens de cunho religioso de diferentes religiões, nas redes sociais, sobretudo no facebook, com especial destaque aos eventos pentecostais, neopentecostais e cristãos de um modo geral. Há, no entanto, pouca divulgação dos eventos e da história dos cultos afrodescendentes, sobretudo a história e a cultura afro-brasileira.A cidade de Porto Velho, na Amazônia brasileira, é um exemplo vivo desta realidade.

Este texto apresenta como tema, os debates nas mídias e o poder simbólico na divulgação de eventos religiosos, afro-brasileiros e das linhagens pentecostais e neopentecostais no facebook. Propomo-nos a mostrar as diferenças existentes entre exclusão social no campo das culturas de massa, por meio de suas crenças e imaginário sócio cultural. Nosso objetivo é também difundir a história e a religiosidade dos povos afrodescendentes, fomentar reflexões e debates, sobretudo nas escolas e Universidades sobre a importância do respeito e reconhecimento da diversidade cultural. Acreditamos ser relevante estudar a história e cultura Africana para contribuir para o reconhecimento e dignidade de seus cultos, ajudando a recuperar suas raízes e difundir a cultura afro-brasileira também na Amazônia.

\section{Algumas reflexões sobre o tema}

Observamos em nosso cotidiano eventos, imagens e reportagens de cunho religioso cristão, espírita, pentecostal sendo divulgados numa multiplicidade de enfoques religiosos jamais vistos nos últimos anos nas redes sociais, sobretudo no facebook. Temos por exemplo a divulgação de eventos de culto pentecostais, neopentecostais e cristãos em geral por toda rede social no mundo todo. Entretanto, a divulgação de eventos sobre a história dos cultos afros brasileiros não é tão comum assim, nas redes sociais. O preconceito e a intolerância religiosa ainda imperam em nossa sociedade de consumo e de uma "vida líquida", segundo Sigmund Bauman (2007). Há uma coisificação e alienação do homem discutido por muitos pensadores e

\footnotetext{
${ }^{1}$ Uma versão anterior deste trabalho foi apresentado ao Núcleo de Ciências Humanas como requisito básico à conclusão da disciplina Cultura Política e Mídia em História e Estudos Culturais pela Universidade Federal de Rondônia - UNIR, conduzida pelo Professor Dr. José Lucas Pedreira Bueno.
} 
já advertido por Karl Marx na obra o Capital (1975).

Observando e pesquisando nas redes sociais como o facebook, podemos perceber que há uma forma de se envolver e conhecer mais sobre cultura religiosa. Em consequência disso, também podemos ver, frequentemente, pessoas preconceituosas e intolerantes que olham para essa questão com a visão etnocêntrica e europeizada, isto é, divulgando a crença que os cultos afrodescendentes são "coisas satânicas", demoníacas e que só suas próprias crenças vindas da Europa contêm a verdade absoluta.

Esse fato já foi registrado em anos de docência, nas aulas de História e Sociologia em escolas públicas de Porto Velho. No geral o que se observa é a questão de não se admitir outras crenças, outros olhares, outros saberes, outro modo de viver e perceber outras visões de mundo. Isso acontece muito hoje no universo cristão pentecostal. As redes sociais estão recheadas de frases e convites na maioria das vezes de cunho excludentes e exploradores, sobretudo no viés capitalista, para eventos, festas e shows. Como por exemplo, temos o seguinte texto postado no facebook, dia 10/11/14:

\begin{abstract}
Arruinando a economia (mas salvando bolsos e fundos dos pastores gospel) Igrejas arrecadam R \$ 39,1 milhões por dia em dízimos e ofertas no Brasil, revela a Receita Federal. A doutrina do dízimo, contestada por muitas pessoas que não praticam a fé cristã - e até por teólogos cristãos - vem se tornando a inspiração para diversas reportagens da mídia."
\end{abstract}

Nesse sentido percebe-se que o preconceito e intolerância religiosa impera no imaginário social, geralmente deleta e exclui essas notícias e informações históricas e culturais tão importante para reconhecimento de nossa identidade. Apesar desse fato, observa-se que já houve um crescimento considerável na divulgação de eventos afros descendentes nas páginas das redes sociais, sobretudo nas páginas do facebook.

Há, por exemplo, um comentário da Antropóloga De Lima, através da página do Facebook, no dia 21/11/13 a respeito de uma festa tradicional e histórica em Porto Velho no terreiro de Santa Bárbara que diz o seguinte:

Gente, quem puder apoiar o Hiago Paiva na realização do Festejo de Terreiro de Mina Santa Bárbara, ajude. O festejo é parte de uma tradição antiga da cidade de Porto Velho e faz parte do legado cultural dos caboclos amazônicos. Todo tipo de ajuda é bem vinda: com alimentos, bebidas (refrigerantes, cerveja, suco...), cigarro, velas, tecidos, madeira, telhas de amianto... Braços, mãos... Quem se interessar entre em contato com ele pelo Face."

Vejam a evolução e a rapidez com que essa notícia se espalhará, como uma teia de aranha fazendo com que esse maravilhoso evento da história regional, aconteça comemorado religiosamente todos os anos no Barracão de Santa Bárbara na Vila Tupi em Porto Velho.

Relatos dos praticantes da religião Umbandista através de pesquisas de campo no dia 11/10/09 foram coletados as seguintes informações: historicamente, o "Recreio de Iemanjá" surgiu no Bairro Mocambo entre os anos de 1911 e 1914; transferiu-se para a Rua Joaquim Nabuco, provavelmente em 1944, dando origem ao Bairro de Santa Bárbara; de onde foi transferido para Rua Venezuela por volta de 1973, e, em torno de 1974 transferiu-se para um outro terreno na mesma rua, no Bairro Nova Porto Velho, por último, em torno de 1978 para a Vila Tupi, onde se encontra até o presente.

Ao visitar e participar da festa de São Sebastião no dia 20/01/2010 em Porto Velho 
foi observado que o terreiro de Santa Bárbara é muito alegre, lúdico, exótico e diferente no sentido de liberdade e humildade de seus praticantes. Ademais, muitas pessoas da alta sociedade, políticos carnavalescos de Porto Velho, se encontram lá para se divertirem e receber seu axé.

Outro aspecto observado que merece destaque é a relação sociocultural interagindo com a comunidade. Pessoas das mais diversas áreas e posições sociais diversas, professores, advogados, funcionários públicos, carnavalescos, membros de outras denominações religiosas se encontram lá para assistir, prestigiar e participar da festa. A interação sócia cultural que se cria nesse clima lúdico de descontração é formidável porque faz com que pessoas se conheçam e troquem ideias, quebrando preconceitos e estereótipos criados no meio social pelo senso comum e pela intolerância religiosa.

Há registros históricos de que na África Ocidental, mais relacionada às Américas, pois a maioria dos escravos é oriunda daquela região, a dança muitas vezes associava intimamente as práticas religiosas. A associação entre dança e religião era mais estreita do que na Europa, onde havia uma longa tradição de hostilidade oficial a danças na igreja ou mesmo por ocasião de festivais religiosos. Entre os Tallensi da África ocidental, por outro lado, o antropólogo Ferretti (1995) que melhor os conhecia sobretudo, o sincretismo religioso, registrou que o terreno da dança é "sagrado". A dança era um ritual que provocava perda de consciência e no qual os dançarinos eram possuídos e uma dança apresentada por negros, mas também um maracatu, ou por espíritos e divindades, como no caso dos Iorubas no Daomé e na Nigéria.

Nesse sentido, não se deve considerar a possessão, ou "mediunidade do espírito", como por vezes é chamada, como uma forma de histeria. Como alguns antropólogos têm enfatizado, a possessão deve ser analisada como ritual e, mesmo, teatro. Os possuídos incorporam seu determinado espírito de maneira muito semelhante à que os foliões do Carnaval personificam o comportamento adequado a seus trajes, sua fantasia.

Alguns desses espíritos se comportam de maneira carnavalesca: os espíritos caboclos na Umbanda, por exemplo, espíritos masculinos que se apossam de mulheres e fazem com que seus veículos humanos fumem, bebam e digam palavrões. O Candomblé afrodescendentes e a Umbanda sincrética foi criada no Brasil pelos negros, segundo Bastides (1989) foi criada no final do século XIX, em sua obra "As religiões africanas no Brasil", de 1989, é um exemplo clássico sobre essa questão.

\section{O imaginário e o simbólico}

Na amostra de texto mitológico abaixo, do sociólogo Reginaldo Prandir, extraída da página do facebook, com acesso em 20/11/14, o autor consegue adaptar os mitos Iorubás de uma forma coerente com a necessidade de se conhecer sobre o imaginário e o simbólico, dessa forma surge a partir do mito de Oxalufan, das lendas e mitos afro-brasileiro. Como observamos na seguinte narrativa de Prandir (2001):

Um dia Oxalufam, que vivia com seu filho Oxaguiam, velho e curvado por sua idade avançada, resolveu viajar a Oyo em visita a Xangô, seu outro filho. Foi consultar um Babalaô para saber acerca da viagem. $\mathrm{O}$ adivinho recomendou-lhe não seguir viagem. Ela seria desastrosa e acabaria mal. Mesmo assim, Oxalufam, por teimosia, resolveu não renunciar à sua decisão. $\mathrm{O}$ adivinho aconselhou-o, então, a levar consigo três panos brancos, limo-da-costa ou sabão-da-costa, assim como a aceitar e fazer tudo que lhe pedissem no caminho e não reclamar de nada, acontecesse o que acontecesse. Seria uma forma de não perder a vida (...) (PRANDIR, 2001, p. 215). 
Sob esta perspectiva, podemos ver no texto de Bourdieu (2007) o seguinte raciocínio:

Todavia o conteúdo do discurso mítico (inclusive sua sintaxe) aos interesses religiosos daqueles que o produzem, que o difundem e que recebem. Em plano mais profundo chega a construir o sistema de crenças e práticas religiosas como a expressão mais ou menos transfigurada das estratégias dos diferentes grupos de especialistas em competição pelo monopólio da gestão de bens de salvação e das estratégias dos diferentes grupos e as classes interessadas por seu serviço. Neste ponto, Weber está de acordo com Marx ao afirmar que a religião cumpre uma função de conservação da ordem social contribuindo nos termos de sua própria linguagem, para a "legitimação" do poder dos "dominantes" e para a domesticação dos dominados. (BOUDIEU, 2007, p. 32).

É notório o nível de coerção e manipulação religiosa por parte dos dirigentes, sobretudo das igrejas pentecostais e neopentecostais, em especial para os que ali vão a busca de realização pessoal, e enriquecimento rápido. E o que se vê é os pastores simbolizando sua vitória e realização pessoal de poder como fonte obtida do que pregam, como se pode constatar na seguinte propaganda postada no facebook dia 13/12/14 de uma Igreja Pentecostal em Porto Velho:

Aproveitem o seu décimo e faça uma doação significativa, doe seu décimo para Deus aqui na igreja, dia 31/12/13 você passará por um túnel de luzes simbolizando o fogo e lá na frente depositará seu décimo terceiro, e será ricamente abençoado em 2014.

Observa-se claramente a intenção capitalista e manipuladora dessas igrejas e denominações religiosas cristãs por toda parte. Abrir igrejas se tornou um grande negócio que cresce e se propaga dia a dia. A massa social que representa a grande maioria cresce em busca de melhores condições de vida, lazer, comida, casa e, sobretudo um Deus Salvador de suas vidas como compensação de tanto trabalho duro e sofrimento. É ai que entra a igreja e principalmente as religiões cristãs Pentecostais sobre o viés da prosperidade e riqueza a curto espaço de tempo.

Para Adorno e Horkheimer (2002) "a indústria cultural possui padrões que se repetem com a intenção de formar uma estética ou percepção comum voltada ao consumo". Nesse viés capitalista, a Indústria Cultural pode ser um fator primordial na formação de consciência coletiva nas sociedades massificadas, nem de longe seus produtos são artísticos. Isso porque esses produtos não mais representam um tipo de classe (superior ou inferior, dominantes e dominados), mas são exclusivamente dependentes do mercado. A Indústria Cultural distingue-se de cultura de massa, esta é oriunda do povo, e das suas regionalizações, costumes e sem a pretensão de ser comercializada, enquanto que aquela possui padrões que sempre se repetem com a finalidade de formar uma estética ou percepção comum voltada ao consumismo.

Como vimos na leitura de Sigmund Bauman (2007) Vida Liquida, em uma sociedade líquido-moderna, as relações, os hábitos, as formas de proceder, mudam em um tempo muito rápido, isto é, a sociedade em suas atitudes, características, personalidades, caráter, não mantém uma forma variável, ao contrário em questão de segundos, a situação que existia é passado.

Podemos citar, por exemplo, os gostos musicais hoje se alteraram, sobretudo entre a juventude nas escolas igrejas, bairros e associações. Podemos dizer que vida é resumida na valorização de coisas supérfluas, a vida, porém, sempre se reinicia, sendo momentos que são 
rápidos, sem nenhuma importância, ao mesmo tempo em que se livra de alguma coisa, é criada uma forma e estratégica para conseguir novamente. Tornando-se assim, um ciclo constante de modismo e seguimento do que a burguesia e o capitalismo pensam, usa e impõe para todos nós $[\ldots]$.

Em um mesmo momento em que algo é comprado, logo em seguida é descartado e ocorre à criação de uma indústria que tem por finalidade remover todo esse lixo inutilizado, a rapidez com que os produtos são enviados aos depósitos de lixo é realmente assustadora. Tudo é feito para ser descartado, e esquecido. Uma sociedade, onde qualidade de vida depende do seu salário e qualidade de vida, a constância, a aderência e viscosidade das coisas são consideradas perigos mortais, de certa forma, trazendo riscos assustadores e desencadeados verdadeiros ataques culturais violentos. Os indivíduos pertencentes ao mundo líquido capitalista são orientados por especialistas que consideram saber sobre as artes da vida da informática das mídias e redes sociais e o consumo do mercado de bens simbólicos (ORTIZ, 1991).

Dessa forma, a riqueza espiritual está desse ponto de vista, ameaçado pela sociedade de consumo da civilização capitalista, que só produz riqueza material através das máquinas, e o resultado dessa exploração humana é o que dá mais lucro para o sistema do que se preocupar com educação e cultura. É o que vimos nos filmes Metrópoles de Fritz Lang (1927) e Tempos Modernos de Charles Chaplin (1936) cujo conteúdo retrata a dominação das massas trabalhadoras, através das máquinas e a exploração da mão de obra, pelo que Karl Marx denominou de "mais valia". Toda essa manipulação é realizada por um mediador numa visão de futuro a serviço do capital, algo a ser usado no futuro que no caso de hoje seria as mídias filhas dos meios de produção e dominação capitalista.

Nesse sentido podemos observar que não existe nenhum determinismo tecnológico que obrigue os meios de comunicação de massa a disseminar, como fazem o lixo cultural, por exemplo, através das músicas tocadas nas FMs da vida, nas televisões e no mundo virtual das redes sociais, as "massas" são embevecidas e como bem lembrou Karl Marx, sobre o processo de alienação imposta, as pessoas serão alienadas por esse sistema capitalista que praticamente obriga e incentiva as pessoas de forma inconsciente e simbólica a comprarem e consumirem tudo que a mídia e o mercado de bens de consumo oferecem como modismo, dai nasce o lixo cultural. É o que podemos conferir na leitura de Bauman (2007, p. 17): "o lixo é o principal e, comprovadamente mais abundante produto da sociedade líquido-moderna de consumo. Entre as indústrias da sociedade de consumo, a de produção de lixo é a mais sólida e imune as crises."

Podemos observar, por exemplo, nas escolas de ensino Fundamental e Médio esse fato acontecer rotineiramente: o (a) professor (a) ministra o conteúdo mais é interrompido pelos celulares e fones de ouvido dentro da própria sala de aula, ninguém respeita as leis e sobretudo o profissional que está ministrando as aulas. As músicas e os programas que essa juventude corrompida por esse sistema reacionário e excludente canta e gostam ,é sem dúvida um verdadeiro lixo cultural. Isso se dá de forma inconsciente sem que elas percebam é uma espécie de Matrix social alienada, sobretudo politicamente e como consequência influenciados pela própria mídia. Assim, são capazes de pagar 100 reais num show de Michel Teló, mas não reconhecem o valor de um bom livro pagando muito menos por essa ação educativa e cultural, que só iria elevar seus conhecimentos.

Porem o lixo cultural, através do capitalismo e a liquidez, tomam conta de suas mentes e ideias ao ponto de alienar-lhes por completo. O povo assimila, a seu modo, algumas imagens da televisão, algumas músicas e palavras do rádio, traduzindo os significantes no seu 
sistema de significados. Como afirma Bosi (1994) nos seguintes termos:

Há um filtro, com rejeições maciças da matéria impertinente, e adaptações sensíveis da matéria assimilável. De resto, a propaganda não consegue vender a quem não tem dinheiro. Nesse sentido, ela acaba fazendo o que menos quer; dando imagens, espalhando palavras, liquidando o que bem quer, desenvolvendo ritmos, que são incorporados ou re-incorporados pela generosa gratuidade do imaginário popular.” (BOSI, 1994, p. 329)

Como diria Bourdieu (1989) "em uma sociedade hierarquizada e injusta como a nossa, não são todas as famílias que possuem a bagagem culta e letrada de distinguir o que é ou não lixo cultural”. Observa-se que em um país como o nosso com um índice de analfabetismo consideravelmente grande, não dá para se apropriar e se identificar com os ensinamentos escolares.

Alguns, denominados de origem social superior, terão certamente mais facilidade do que outros, pois já adquiriram parte desses ensinamentos em casa. Existiria uma aproximação e uma similaridade entre a cultura escolar e a cultura dos grupos sociais dominantes, pois estes há muitas gerações acumulam conhecimentos disponibilizados pela escola. Nesse sentido, o sistema de ensino que trata a todos "igualmente", cobrando de todos o que só alguns detêm (a familiaridade com a cultura culta), não leva em consideração as diferenças de base determinadas pelas desigualdades de origem social.

Além disso, Bourdieu (1989) detecta um descompasso entre a competência cultural exigida e promovida pela escola e a competência cultural apreendida nas famílias dos segmentos mais populares. Em síntese: para Bourdieu o sistema escolar, em vez de oferecer acesso democrático de uma competência cultural específica para todos, tende a reforçar as distinções de capital cultural de seu público. Agindo dessa forma, o sistema escolar limitaria o acesso e o pleno aproveitamento dos indivíduos pertencentes às famílias menos escolarizadas, pois cobraria deles os que eles não têm, ou seja, um conhecimento cultural anterior, aquele necessário para se realizar a contento o processo de transmissão de uma cultura culta.

Essa cobrança escolar foi denominada por ele como uma violência simbólica, pois imporia o reconhecimento e a legitimidade de uma única forma de cultura, desconsiderando e inferiorizando a cultura dos segmentos populares.

\section{Fatores históricos e culturais africanos}

Desde o período colonial (1500-1822), a ancestralidade africana sempre foi concebida como sinônimo de impureza e contaminação, o que contribuiu para criar e consolidar uma imagem estereotipada e extremamente negativa dos negros e dos pardos em nossa sociedade. A herança deixada pela escravidão em nosso país transformou- se num outro tipo de violência, igualmente cruel: o racismo (FREYRE, 1998), uma realidade presente sob diferentes formas e que somente poderá ser superada quando ocorrerem mudanças sociais e culturais profundas, que diminuam a distância social existente entre negros e brancos. É notório que a desigualdade social vivida pelos negros durante gerações os transformou na maioria da população pobre do país.

Neste contexto, a sociedade brasileira está percebendo que é chegado o momento de se quebrar o silêncio sobre o racismo, o preconceito e a discriminação racial, sobretudo, as mazelas que têm feito com que os afros descendentes em nosso país tenham sido vistos até 
agora de maneira incompatível com o sentido de uma sociedade igualitária.

Percebe-se que essa realidade tem contribuído para inibir, por exemplo, o desabrochar integral de todos os campos das ciências humanas e significados sem distinção, inclusive intelectualmente nas escolas e universidades. Pelo o que podemos observar dos resultados das pesquisas realizadas nas Escolas públicas in locos, de porto Velho. Percebe-se que a história ensinada nas escolas apresenta a civilização ocidental como padrão de referência em termos civilizatório e o eurocentrismo que infelizmente tem vigorado de forma unânime como modelo de ensino da história. A história da África encontra-se no currículo, muitas vezes, diluídas na própria história Geral ou quando muito na história do Brasil. Assim estudamos com muito maior profundidade a antiguidade dos mesopotâmicos, dos gregos, dos romanos e permitimos isso no nosso cotidiano, entra ano e sai ano, reuniões e mais reuniões e nada modifica, a ausência em nossos currículos da história e cultura da África é uma realidade. O que se pode perceber que é uma perda muito grande de conhecimento de povos que sabiamente, exerceram influências culturais sobre nós de forma indiscutível. Contudo, continuamos a refutálos, em um ato consciente de negação de nossa própria identidade. É o que podemos perceber na leitura de Cevasco (2003) nos seguintes termos:

Esses significados são culturais, adquirem existência perceptível por meio dessas formas culturais, e são modificados na medida em que entram em conjunção com pessoas em situações específicas que os podem aceitar, modificar ou recusar. Assim, não é de admirar que Williams, Hoggart e Thompson tenham se interessado pela cultura dos de baixo, buscando formas de resistência à cultura capitalista nos significados, valores e reconhecimentos produzidos pelos que o sistema deixa de fora e explora. (CEVASCO, 2003, p. 69)

Na leitura de Ortiz (1991) podemos observar elementos críticos sobre o racismo. Há alguns anos a identidade feminina, a identidade étnica eram pouco lembradas. Mesmo a discussão, no Brasil, sobre a questão racial sempre esteve, de certa forma, imprensada entre ser negro ou não ser negro. Através dessa temática percebe-se que a discussão sobre a cultura nacional sempre predominou com relação à discussão sobre a cultura negra. Mas por que o "nacional" não é negro? Vimos por exemplo nos livros didáticos, sobretudo de história, a pobreza e o etnocentrismo como pano de fundo, com que os conteúdos são tratados a respeito da cultura e história africanas, pequenas páginas observadas nas escolas públicas em todas as séries apontam para essa realidade. Esquece-se que o país é predominantemente negro. Em Porto Velho, segundo pesquisador professor Dr. Marcos Teixeira apenas seis por cento da população se declara negra. ${ }^{2}$

Ainda convém lembrar que os livros de história selecionados pelo PNLD em 2013, na sua maioria, trazem capítulos específicos sobre a história da África ou sobre a relação dela com a história do Brasil. Porém, com relação às obras do ensino fundamental através da SECADI (Secretaria de Educação Continuada, Alfabetização, Diversidade e Inclusão) a análise presente no Guia do MEC. Brasil (2004) diz que: "para muitas obras, nos momentos históricos subsequentes à colonização, em relação ao movimento abolicionista, por exemplo, o tratamento dispensado ao tema valoriza as concepções tradicionais, que secundarizam a participação dos afro-brasileiros no processo. Os guias também apontam que, na maioria dos livros didáticos da disciplina, a contribuição dos negros africanos brasileiros para a cultura nacional aparece associada à música, à dança, à alimentação, à religião, às festas e a termos incorporados à língua

\footnotetext{
${ }^{2}$ Palestra proferida no auditório da UNIR-CENTRO em 4 de novembro de 2015.
} 
portuguesa. Explica ainda que é importante que os professores valorizem com os alunos esses aspectos da cultura afro-brasileira, mas sem que sejam reproduzidos estereótipos. É preciso lembrar sempre que a arte negra está ligada a uma produção artística histórica, reflexiva e de resistência. Já o material usado nas aulas de geografia aborda a cultura afro-brasileira e a diversidade étnica do Brasil de forma genérica e não estrutural nos conteúdos específicos de cada série.

Nas análises das obras do ensino fundamental, por exemplo, o MEC (BRASIL, 2004) ressalta que: "a maior parte dos livros em questão trata essa contribuição — indígena e afrodescendente - como sendo parte de um momento específico da formação territorial e não como constituinte do espaço geográfico na atualidade".Com relação ao ensino fundamental, foram constatadas falhas das obras que dão "pouco ou nenhum destaque ao papel da mulher, do indígena e do afrodescendente na sociedade contemporânea, especialmente na brasileira, com pouca ênfase nas especificidades locais e regional.

A análise do ministério mostra ainda que "do total dos 24 livros de história de abordagem nacional e regional para o ensino fundamental e médio inscritos no edital de 2014, somente a metade aborda positivamente a cultura afro-brasileira e dos povos indígenas" na escola. Macaé Evaristo (2013) secretária da SECADI do MEC, diz que: "o órgão cumpre seu papel e que realiza a produção de conteúdos específicos de apoio aos professores. O que a gente precisa perceber é que nós estamos lutando contra 500 anos de racismo". Nesse sentido podemos perceber que a Lei 10.639/03 foi criada para desconstruir uma lógica que estruturou a sociedade brasileira. Então estamos falando de uma concepção de transformação da escola e da educação do País. O ensino da cultura negra nas escolas foi introduzido pela Lei 10.639/03, de 2003. Cinco anos depois o governo federal sancionou outra norma, a Lei $11.645 / 08$, que determina que "os conteúdos referentes à história e cultura afro-brasileira e dos povos indígenas brasileiros serão ministrados no âmbito de todo o currículo escolar, em especial nas áreas de educação artística e de literatura e história brasileira [...] nos estabelecimentos de ensino fundamental e médio, públicos e privados".

\section{Os festejos de santo nos terreiros de umbanda e candomblé em Porto Velho-RO}

As atividades ritualísticas desenvolvidas no Barracão de Santa Bárbara em Porto Velho de Linhagem Umbandista são divididas em duas categorias amplas: "betenção" e tambor de obrigação. Desta última faz parte uma série de ritos denominados tambor menor e festejos grandes, eles variam conformo o calendário ritualístico. As comemorações mais importantes do terreiro são dedicadas a Santa Bárbara, identificada como "Yansã", e a São Sebastião, identificado como Oxóssi. Segundo os relatos, Houve uma época em que havia diversos ciclos rituais que pertenciam a essa categoria, hoje em dia existem apenas dois: os festejos de junho (24/06) e os festejos de Santa Bárbara (26/11 a 20/01). Desse o único que vem sedo cumprido sem alteração nas datas são os festejos de Santa Bárbara. Através investigações de campo realizado no dia da festa de Santa Bárbara dia 20/01/06, alguns adeptos da casa afirmaram que historicamente os fundadores eram negros de descendência mina, que trouxeram para Porto Velho o legado cultural afro-brasileiro do tronco fon-yoruba através dos rituais do Tambor de Mina, que se popularizaram com a denominação de Tambor, Batuque, Macumba e também Umbanda. 
Os depoimentos coletados indicam que a irmandade de Santa Bárbara possuía uma capela e um barracão e explicam que rezavam na capela e dançavam no barracão onde se praticava os cultos de origem mina-nagô ${ }^{3}$. O ritual da festa religiosa começa as 19/00 horas os praticantes da religião umbandista sincrética com o catolicismo, rezam o terço e cantam músicas católicas na capela ao lado do barracão, iniciando o ritual sincrético religioso. O altar da capela de Santa Bárbara é recheado de imagens de santos católicos, tendo a imagem de Santa Bárbara no centro simbolizando a força o axé espiritual do terreiro. Filha de Oxalá e Iemanjá Iansã tem atributos da sensualidade, representada sempre como uma mulher forte que porta uma espada e um iruexem (espécie de chicote) também é senhora dos eguns, os (espíritos dos mortos) seus domínios são os ventos, as tempestades, os rios e o fogo. É formado um circulo no centro do salão do terreiro, onde os atabaques começam a soarem tocados pelos mestres especialistas nessa função primordial do ritual, nota-se que sem toque de tambor não existe animação, os caboclos e orixás não descem, em fim, sem os toques dos tambores não existe festa nem axé. Outra observação importante é o uso do defumador sempre presente, do início ao fím, utilizado basicamente para purificação e descarrego de algumas energias negativas que possam prejudicar o andamento dos trabalhos durante a festa.

O contato pessoal com essas comunidades religiosas de matrizes africana, foi formidável muito rica e prazerosa no campo da pesquisa sócio cultural afrodescendentes. $\mathrm{O}$ terreiro de Santa Bárbara é muito alegre lúdico, exótico e diferente no sentido de liberdade e humildade de seus praticantes. Um outro aspecto observado que merece destaque, é a relação sócio cultural interagindo com a comunidade. Pessoas das mais diversas áreas e posições sociais, professores, advogados, funcionários públicos, carnavalescos, membros de outras denominações religiosas se encontram lá para assistir, prestigiar e participar da festa.

Observando pelo viés religioso sincréticos, os cultos de possessão continuam entre os negros nas Américas, desde o vodu do Haiti, à santería de Cuba e ao candomblé do Brasil (que tem ligações particularmente estreitas com as tradições iorubas), ou seu equivalente no Maranhão, o tambor-de-mina, nome que enfatiza a batida do tambor. Nesse sentido, não se deve considerar a possessão, ou "mediunidade do espírito", como por vezes é chamada, como uma forma de histeria. Como os antropólogos têm enfatizado, a possessão deve ser analisada como ritual e até mesmo teatro. Os possuídos incorporam seu determinado espírito de maneira muito semelhante à que os foliões do Carnaval personificam o comportamento adequado a seus trajes, sua fantasia.

Alguns desses espíritos se comportam de maneira carnavalesca: os espíritos caboclos no candomblé, por exemplo, espíritos masculinos que se apossam de mulheres e fazem com que seus veículos humanos fumem, bebam e digam palavrões. Dentro do terreiro existe uma rede de sentidos e energias inimagináveis. Há registros históricos de que batuque dos tambores era fundamental para esses rituais de possessão desde o mundo antigo. Os tambores eram considerados as vozes das divindades, cada uma associada a um ritmo característico.

É interessante observar que essas práticas religiosas deram uma importante contribuição aos carnavais afro-americanos. O lugar dos tambores nesses carnavais é fundamental nos casos das baterias do Rio e da "orquestra de metais" de Trinidad (que substituiu os tambores tradicionais na

\footnotetext{
${ }^{3}$ Mina-Nagô: A maioria dos negros escravos introduzidos na Bahia tomaram a denominação geral de nagôs, termo usado pelos franceses para denominar os escravos que falavam iorubá (dialeto nigeriano), mais especificamente os da cidade de Keto.
} 
década de 1930). As danças do candomblé são às vezes comparadas ao samba do Carnaval não apenas por observadores, mas também por participantes.

No Brasil, incorporaram-se outras práticas religiosas ao Carnaval, por meio do afoxé, palavra que significa não apenas um instrumento musical (a maraca) um cortejo carnavalesco de adeptos do candomblé. O compositor e cantor brasileiro Gilberto Gil conta que, quando desfilava no Carnaval de Salvador com o resto de seu grupo de afoxé, certa vez viu uma mulher de meia-idade benzer-se, na certa pensando que o que estava vendo era uma procissão religiosa.

Em todos os rituais religiosos acima descritos, as mulheres têm tradicionalmente desempenhado um papel importante dentro do terreiro ou de sua Casa de Santo. Os cultos de possessão de Hausa Bori eram e são controlados por mulheres. A chamada "mãe-de-santo" Ialorixá continua sendo a figura central no candomblé. No Recife, as rainhas que conduzem os maracatus no carnaval são mães-de santo.

Para reforçar a hipótese da ligação entre religião africana e Carnaval americano, pode-se acrescentar que, em Salvador, espíritos femininos chamados tobosses ("moças") "baixavam" no Carnaval, que as tão destacadas baianas do Carnaval do Rio e de outras cidades, senhoras dignas que rodopiam em seus longos vestidos brancos.

Ao analisar o sistema simbólico e ideológico das crenças e religiões, o poder simbólico distingue-se fundamentalmente conforme aponta Bourdieu (1989, p.12-13) nos seguintes termos:

\begin{abstract}
A história da transformação do mito em religião e ideologia não se pode separar da história da constituição de um corpo de produtores especializados de discursos e de ritos religiosos, quer dizer, do progresso da divisão do trabalho religioso, que é ele próprio, uma dimensão do progresso da divisão do trabalho social, portanto, da divisão em classes e que conduz, entre outras consequências, a que se desapossem os laicos dos instrumentos de produção simbólica.
\end{abstract}

Nesse viés descrito por Bourdier, o poder simbólico como o poder de constituir o, dado pela enunciação de fazer crer, de confirmar ou de transformar a visão de mundo e desse modo, a ação sobre o mundo, um novo olhar uma nova perspectiva de vida, entre os que exercem o poder e os que lhes estão sujeitos, isto é, na própria estrutura do campo em que se produz e se reproduz a crença.

Atualmente o processo neocolonizador cristão assumiu uma roupagem mais perigosa conhecida como inculturação, táticas usadas por algumas igrejas cristãs de manter e levar a ideologia branca a comunidades tradicionais, com um novo discurso de acolhimento as práticas milenares e não cristãs. As "táticas" de enculturação são símbolos de manipulação identitária, destruição cultural e apropriação das riquezas na África e de seus descendentes nas Américas, como no caso dos povos indígenas.

Quando refletimos a conversão ao cristianismo podemos fazer uma viagem ao passado dos ancestrais e rememoramos o que aconteceu: invasão, destruição, mudanças econômicas e territoriais, escravidão e perca da ancestralidade (AGUESSY,1977) "Não são recordações que tragam felicidades. Se viajássemos no tempo e retornássemos ao viver dos nossos ancestrais os encontraríamos com suas concepções teológicas de vida e morte equilibradas".

Levando-se em consideração esses aspecto no cristianismo, nós encontramos uma história de tristeza, sequestro, de aprisionamento de uma guerra religiosa onde nossos ancestrais foram forçados a aceitar o pensamento do homem branco. $\mathrm{O}$ encontro do nosso povo com o cristianismo foi um encontro de morte e não de vida. $\mathrm{O}$ reencontro do nosso povo com a ancestralidade é uma ressurreição da morte branca para a vida preta plena. Torna-se necessário 
voltarmos a ter dignidade e respeito à história dos nossos antepassados e suas concepções teológicas e entendermos que para os africanos e seus descendentes o cristianismo deixou um legado de milhões de mortes, destruição de diversas culturas e civilizações.

Nesse sentido, não adianta propagar que o Deus cristão não faz acepção de pessoas, porque o deus do cristianismo criado em Roma, e posteriormente mascarado com a Reforma Protestante é o mesmo. É o que comenta (FANON,1968,p.176) "para o colonialismo este vasto continente era uma toca de selvagens, uma região infestada de superstições e fanatismo fadada ao desprezo, atingida pela maldição de Deus, terra de antropófagos, terra de negros".

Dentre os inúmeros motivos que levaram os colonizadores atuarem ideologicamente ditando tudo para o africano e os povos indígenas, durante todo o período colonial brasileiro, tomando posse das suas terras e riquezas, explorando - os, roubando-lhes a sua existência, sobretudo, sua história e o que é de mais sagrado suas crenças e costumes em fim, sua cultura.

Em Cartografia dos estudos culturais, pode- se ver o seguinte: sofrem o que Ianni (apud Ana, 2010, p. 11) já problematizou, identificando que "o processo de globalização envolve uma ruptura de amplas proporções, abalando mais ou menos profundamente os quadros sociais e mentais de referência (...) tratando-se de uma ruptura simultaneamente histórica e epistemológica".

No que diz respeito aos estudos culturais, apenas algumas dessas mudanças foram mapeadas e circulam no meio acadêmico através de textos que tomam a própria tradição como objeto de análise. Foco central da obra, ela revela, através explanação dos seus eixos teóricos a questão da ideologia, da hegemonia, problemática do popular e das identidades, que o corpo teórico-metodológico associado aos estudos culturais, configurado a partir do final dos anos 50, na Inglaterra, passou por alguns desdobramentos políticos e sociais.

Portanto, das reflexões embrionárias de sua formação, em especial sustentadas por Richard Hoggart, Raymond Williams e E.P.Thompson, a prática contemporânea dos estudos culturais da virada do século XX para XXI, nos faz perceber a importância das Universidades investirem nas pesquisas e cursos de pós-graduação Strictu Senso e doutoramento no campo dos estudos culturais e da literatura Africana.

\section{Considerações finais}

Levando-se em conta o que foi observado, percebemos o quanto as mídias, por meio das redes sociais como o facebook, ajudam-nos na informação e divulgação dos diversos eventos culturais de cunhos religiosos, políticos e sociais, interagindo no mundo líquido, em que, segundo, Bauman(2007) as relações, os hábitos, as formas de proceder, mudam em um tempo muito rápido. Além disso, Bauman(2007) também enfatiza que a sociedade em suas atitudes, características, personalidades, caráter, não mantém uma forma estável. Ao contrário em questão de minutos, o que existia de tecnologia e programas se torna obsoleto, sobretudo no mercado consumidor. Nesse sentido, Bourdieu (1989) põe em discussão, um consenso muito em voga, relativo à crença de que, gosto e estilos de vida seriam uma questão de foro íntimo. Para o autor, o gosto seria, ao contrário, o resultado de imbricadas relações de força poderosamente alicerçadas nas instituições transmissoras de cultura da sociedade capitalista. Para fundamentar essa afirmação, Bourdieu argumenta que essas instituições seriam a família e a escola; seriam elas responsáveis pelas nossas competências culturais ou gostos culturais. 
A pequena contribuição desse trabalho esperamos que seja combater o racismo e a discriminação religiosa contra afrodescendentes, tendo como referencial os trabalhos de campo e como in locos nas escolas de ensino público de Porto Velho. Queremos alcançar relações positivas de tolerância e respeito com as diferenças, fortalecer entre os negros e despertar entre os brancos a consciência negra, sobretudo os aspectos culturais e históricos de suas raízes.

O Dia da Consciência Negra também põe em pauta a importância de discutir a temática negra nas escolas públicas. Observa-se que, a grande maioria das escolas públicas só lembram da história e da cultura africana no dia 20 de novembro, pelo qual se comemora o dia Nacional da Consciência Negra. A inclusão de assuntos ligados à África e ao povo negro na educação formal é uma das estratégias para reconhecer a presença desse grupo na história do Brasil - segundo fontes do IBGE,(2010) os negros correspondem a 5,8\% da população brasileira, mas os chamados "pardos" chegam a um número próximo da metade da população brasileira.

Não é em vão que as escolas e instituições diversas, já reconhecem a importância de trabalhar a cultura negra em seu dia a dia. Hoje, a lei brasileira obriga as escolas a ensinarem temas relativos à história dos povos africanos em seu currículo, baseando-se pela lei 10.639/03 sancionada pelo ex - Presidente da República, Luiz Inácio Lula da Silva. Porém o que se percebe é muita resistência por parte dos professores(as),o preconceito e intolerância religiosa no que se refere a trabalhar essa temática sobretudo nas escolas. Além disso, os Parâmetros Curriculares Nacionais (PCN's, 1998) estabelecem que a diversidade cultural do país deva ser trabalhada no âmbito escolar. "A sociedade em que vivemos valoriza outro estereótipo, o que resulta na inviabilização do negro. Isso tem um efeito bastante perverso: as crianças negras nunca se vêm e o que elas olham é sempre diferente delas" - explica a professora Roseli, que coordenou o grupo responsável pelo documento sobre Pluralidade Cultural nos PCN's. Assim, entendemos que a pluralidade cultural é um tema que pode ser abordado de forma transversal, em várias disciplinas e durante todo o ano letivo.

Estratégias simples, como a introdução de filmes teatro de fantoches, palestras e discussões sobre a temática, podem ter um efeito positivo para reforçar a identificação cultural dos alunos negros e tornar o ambiente mais tolerante, sobretudo valorizar e respeitar sua própria cultura e origens. Revelar a África pela própria visão africana também surte efeito. O continente produz cultura, histórias e mitologia, o que a perspectiva eurocêntrica não nos deixa ver. Dessa maneira, a criação das referidas leis aponta, ao mesmo tempo, para uma necessidade e para uma omissão. Ou seja, se por um lado, o Brasil avança ao reconhecer a importância de tais temáticas no contexto educacional; por outro, essa medida denuncia o apagamento e a negação experimentados ao longo do tempo. Por isso, é válido discutir o ensino da Literatura negra nesse cenário. Segundo a autora negra Conceição Evaristo (1996) "a textualidade afro-brasileira não condiz com a estereotipia e o apagamento dos corpos, sujeitos e heranças culturais africanas verificadas em parte da literatura brasileira". Assim, o trabalho com a literatura negra em sala de aula possibilita o acesso a uma produção literária que rompe com uma tradição canônica na qual predominam autoria e personagens não negros. Além disso, cria novas representações da figura do negro, questiona, revisa e reclama o seu papel e lugar na sociedade brasileira. Para os estudantes, o contato com a literatura negra pode significar a construção de outra imagem de si e da comunidade afro-brasileira, distinta daquelas verificadas em outros espaços de produção.

Há na literatura negra, produções que podem ser trabalhadas desde as séries iniciais até as mais avançadas. Podemos citar por exemplo atualmente: A divulgação nas redes sociais 
através do Facebook, e do instituto Geledés o Material de Apoio ao Educador uma coleção literária, Intitulada: História e Cultura Africana e Afro-brasileira na Educação Infantil, disponível para Download, promovido pela Unesco inteiramente grátis. Vale ressaltar que os textos tratam das personagens negras, a beleza dos cabelos crespos, a presença da religiosidade de matriz africana e afro-brasileira e relações com a ancestralidade passam a figurar no imaginário infantil, criando para os pequenos novos referenciais. Da mesma forma, os leitores jovens e os adultos experimentam vivências literárias de lutas, desafios e olhares que desconstroem o lugar de subalternidade ao qual sujeitos negros foram e são, em alguma medida, submetidos.

Dentre outros benefícios, o trabalho com a literatura negra possibilita a quebra do silencio historicamente imposto; estimula a discussão sobre questões raciais; é instrumento para o fortalecimento da autoestima negra e combate ao racismo; visibiliza a produção de autores que ainda encontram dificuldades no mercado editorial. Além disso, trazer para o currículo escolar tal produção é uma forma de promover e garantir a diversidade tão necessária para a formação educacional. Nota-se que há ainda uma visão totalmente eurocêntrica que de certa forma procura, mesmo que inconscientemente, negar a relevância da presença africana na cultura brasileira na Escola, e na sociedade.

\section{Referências}

ADORNO, Theodor W, Indústria cultural e sociedade / Theodor Adorno; São Paulo Paz e Terra, 2002.

AGUESSY, Honorat. Visões e percepções tradicionais. In: BALOGUN, Ola et al. Introdução à cultura africana. Lisboa: Edições 70, 1977, p. 95-136.

BRASIL. MEC, CNE/CP 003/2004, Diretrizes Curriculares Nacionais para a Educação das Relações Étnico - raciais e para o Ensino de História e Cultura Afro-brasileira e Africana. Ministério da Educação MEC, Brasília, DF.2004.

BASTIDE, Roger. As religiões africanas no Brasil: contribuição a uma sociologia das interpretações de civilizações. $3^{\text {a }}$ ed. São Paulo, Pioneira, 1989.

BAUMAN, Zygmund. Vida Líquida. Rio de Janeiro, Editora Zahar, 2007.

Capitalismo parasitário: Rio de Janeiro. Editora Zahar, 2010.

BOSI, A. Cultura brasileira $\mathbf{x}$ culturas brasileiras. In:

São Paulo. Companhia das Letras, 1994.

Dialética da Colonização.

BURKE, P. Estruturas da cultura popular. In: Cultura Popular na Idade Moderna: Europa, 1500 - 1800. São Paulo: Companhia das Letras, 1995.

Unidade e variedade na história cultural. In: Variedades de história cultural. Rio de Janeiro: Civilização Brasileira, 2000.

CEVASCO, M. E. Dez lições sobre Estudos Culturais. São Paulo: Boitempo Editorial, 2003.

DE Lima, Marta Valéria. Barracão de Santa Bárbara em Porto Velho - RO. Mudanças e 
transformações das práticas Rituais. Recife; UFP, 2001. Dissertação (Mestrado em Antropologia), Universidade Federal de Pernambuco, 2001.

EVARISTO, Conceição. Literatura Negra: Uma poética de nossa afro-brasilidade. Dissertação (Mestrado) - Departamento de Letras, Pontifícia Universidade Católica do Rio de Janeiro, Rio de Janeiro, 1996.

ESCOSTEGUY, Ana Carolina D. Cartografias dos estudos culturais - Uma versão latinoamericana - ed. on-line - Belo Horizonte: Autêntica, 2010.

FANON, Frantz. Os condenados da Terra. Trad. José Lourênio de Melo. Rio de Janeiro: Civilização Brasileira, 1968.

FERRETTI, Sergio Figueiredo. Repensando o sincretismo: estudo sobre a casa das Minas. São Paulo: Edusp, 1995.

FREIRE, G. Características gerais da colonização portuguesa do Brasil: formação de uma sociedade agrária, escravocrata e híbrida. In: Casa-Grande e Senzala: formação da família brasileira sob o regime da economia patriarcal. Rio de Janeiro: Record, 1998.

GELEDÉS - Instituto da Mulher Negra - São Paulo, http://www.geledes.org.br/, acessado em $16 / 11 / 2014$.

HOGGART, Richard. As Utilizações da Cultura 1 e 2. Lisboa, Editora Presença LTDA, 1957.

I.B.G.E. Retrato Negro No Brasil/Censos Demográficos, Fonte: 2010. São Paulo, http://www.geledes.org.br/, acessado em 10/08/2014.

LEI DE DIRETRIZES E BASES DA EDUCAÇAO NACIONAL (LDB), Lei $\mathbf{n}^{\mathbf{0}}$ 9394, de 20 de dezembro de 1996.

Marx, Karl \& Engels, Friedrich. (1983), A ideologia alemã. São Paulo: Hucitec,1946. O Capital. Rio de Janeiro: Civilização Brasileira, 1975.

ORTIZ, R. A moderna tradição brasileira. Cultura Brasileira e Indústria Cultural. São Paulo: Editora Brasiliense, 1991.

PRANDIR, Reginaldo. Mitologia dos Orixás. 7. ed. São Paulo: Companhia das Letras, 2001.

PIERRE, Boudieu. O poder Simbólico. Rio de Janeiro: RJ, Editora Difel S.A, 1989.

THOMPSON, E. P. A formação da classe operária trabalhadora inglesa. São Paulo: Paz e Terra, 1988.

WILLIAMS, R. Uma tradição do século XIX. In: Cultura e Sociedade: $1780-1850$.

São Paulo: Companhia Editora Nacional, 1969. 


\title{
A utilização da mídia escrita e da caravana ford como estrátégias do governo de Rondônia para conclusão da BR-29
}

\author{
Washington Heleno Cavalcante (UNIR)
}

\section{Introdução}

O Governo de Juscelino Kubitschek (1956-1961) trouxe ao cenário nacional um claro período desenvolvimentista baseado nos projetos conhecidos como Programa de Metas, que possuía 31 objetivos, contidos em seis grandes metas: energia, transportes, alimentação, indústria de base, educação e construção de Brasília.

A pacificação das lideranças políticas do país, inclusive dos setores internos das Forças Armadas, foi o principal facilitador para o desempenho do Programa de Metas. No campo militar, os oficiais de alta patente estavam divididos em duas vertentes ideológicas, a maioria, entretanto, estava voltada para a manutenção da democracia, contanto que fosse possível a manutenção da ordem interna e o combate aos comunistas. Por outro lado, havia oficiais nacionalistas, dentre os quais alguns nutriam simpatia pelos comunistas. Tais militares fomentavam um nacionalismo radical em confronto ao imperialismo estadunidense (FAUSTO, 2001).

O início do governo de Juscelino Kubitschek tendo como mote "o desenvolvimento e a ordem", foi um prenuncio de apaziguamento das mazelas ideológicas entre os militares. Por outro lado, o presidente buscou logo no início de seu governo atender as reivindicações das corporações militares, tanto na questão salarial quanto na questão técnica com a aquisição de equipamentos.

A indicação do general Lott para o Ministério da Guerra e a convocação de militares para postos governamentais estratégicos como Petrobrás e Conselho Nacional do Petróleo serviram como fator conciliador entre o Governo e as Forças Armadas (FAUSTO, 2001).

No que tange à política partidária, as definições ideológicas do PSD e PTB, ao longo de dez anos, remeteu a uma natural conciliação que no âmbito do Congresso, facilitou as ações e projetos do Governo.

De certa forma, Juscelino Kubitschek, em boa parte de seu governo, terminou sintetizando os limites de ação desses dois partidos visto que o lema "desenvolvimento e ordem" eram adequados ao PSD de onde era oriundo. No campo social, não se opôs às vontades da burocracia sindical embora tenha tratado de limitar as greves, demonstrando com isso que não limitaria as ações do PTB e de Jango sem, contudo, fazer seu jogo.

Livre de pressões políticas que pudessem dificultar seu plano de governo JK passa a desempenhar a política econômica baseada no Programa de Metas com o direcionamento de ações efetivas nos setores de energia, transportes, indústria de base, educação e construção de Brasília, como já foi citado. 
Numa consequência natural, o programa previa uma gradativa elevação no padrão de vida das populações mais carentes. Na verdade, de um contingente excluído ainda dos bens de consumo, em um claro movimento de mudança na cultura política do país. O carisma e entusiasmo do presidente, midiaticamente divulgado na imprensa nacional, escrita e falada, obtinha a solidariedade da sociedade.

A construção de Brasília, como carro chefe do Programa de Metas e o esforço pessoal do presidente, terminou se transformando no fator aglutinador da população em torno do apoio ao projeto do Governo (PENNA, 1999).

Ainda, no que tange ao Programa de metas, o Governo incentivou a implantação de indústrias automobilísticas estrangeiras em Território Nacional. As empresas foram atraídas para o Brasil pelas facilidades concedidas e, sobretudo, aos potenciais do mercado Brasileiro. Dentre as principais empresas automobilísticas implantadas nas cidades de Santo André, São Bernardo e São Caetano, no estado de São Paulo, podemos citar: Willys Overland, a Ford, a Volkswagen e a General Motors.

O desenvolvimento da indústria automobilística e a mudança do centro administrativo do país para a região Centro Oeste remetiam à necessidade da melhoria da malha viária, composta por pouquíssimas estradas que se concentravam principalmente na região litorânea do país.

Neste cenário, surge a ideia da construção de uma rodovia de vital importância para o desenvolvimento econômico da Amazônia, que poderia compor o Programa de Metas do Governo JK, que visava, além dos interesses econômicos locais, a integração nacional. Trata-se da BR-29, hoje chamada BR-364. A rodovia BR-029 tinha como projeto inicial a ligação terrestre entre Cuiabá-MT e Rio Branco-AC, passando por Porto Velho-RO.

O projeto de construção da BR-29 ocorreu em um cenário no mínimo curioso, através da solicitação pessoal do então governador do Território de Rondônia, Paulo Nunes Leal ao presidente da República Juscelino Kubitschek (LEAL, 1986).

Vários fatos interessantes envolveram o projeto de construção da BR-29 ao longo do ano de 1960, quando foi construída. Dentre estes fatores a utilização da mídia escrita por intermédio de jornais e revistas e a participação da Comissão Ford, que foi uma comissão composta por jornalistas, engenheiros, militares, mecânicos e motoristas. Foram elementos que contribuíram efetivamente para a agilização da conclusão das obras da BR-29.

Estudar o processo de construção da BR-29, sobretudo a participação ativa das rádios e jornais, informando, fomentando, influenciando e tomando partido político e ideológico, é importante para um melhor entendimento do papel mediador da imprensa nas ações do Estado e nas mudanças, muitas vezes involuntárias da opinião pública, por força do papel midiático.

O presente artigo tem como objetivo central analisar o papel dos jornais e revistas, como instrumentos de divulgação das ações do Governo Federal na construção da BR-029, estando o referido empreendimento integrado ao Programa de Metas projetado por Juscelino Kubitschek.

Pela análise do papel dos jornais no projeto de alardear um possível fracasso do Governo Federal em construir uma rodovia, pode-se compreender a importância dos meios de comunicação e, o estágio tecnológico vivenciado pelo país pela própria estrutura midiática utilizada. De acordo com Mcluhan (1969, p. 21): "Numa cultura como a nossa, há muito acostumada a dividir e estilhaçar todas as coisas como meio de controla-las, não deixa, às vezes, 
de ser um tanto chocante lembrar que, para efeitos práticos e operacionais, o meio é a mensagem".

Em segunda instância, busca ainda analisar o papel da Caravana Ford como elemento fundamental para divulgação da necessidade de se concluir a construção da BR-29, justamente no momento em que as obras encontravam-se quase paralisadas. Dessa forma, acompanhada de jornalistas que irão divulgar nos periódicos de grande circulação em todo país a sua saga, a Caravana Ford apresenta-se como fator de estímulo para a conclusão da referida rodovia.

\section{Antecedentes da construção da br-029}

Chegar ao Território Federal de Rondônia antes da construção da BR-029 era uma empreitada difícil e muitas vezes arriscada. Os meios de transporte mais utilizados eram as embarcações que navegavam pelo rio Amazonas e Madeira. Chegar à Rondônia, dessa forma, dependia do transporte fluvial, via Manaus.

Existem relatos da chegada de aventureiros que vieram pelo mato Grosso, até a antiga Vila Bela da Santíssima Trindades de onde, pelo rio Guaporé chegavam à Guajará Mirim e depois à Porto Velho, contudo foram casos raros, com relação à chegada ao Território de Rondônia, antes da construção da BR 029, afirma Kubitscheck:

\footnotetext{
Um mês antes, o governador do Território de Rondônia, o Coronel Paulo Nunes Leal, havia autorizado a realização da viagem pioneira de um caminhão, carregado com quatro toneladas, da capital pau lista a Porto Velho, e essa iniciativa havia sido coroada de pleno êxito. O tempo gasto no percurso fora muito menor; houve considerável economia para os cofres públicos; a carga chegara em perfeito estado; e ficara provada a viabilidade da travessia de veículos entre aqueles extremos, levada a efeito através do Centro-Oeste do País, (KUBITSCHECK, 2000, p. 203).
}

O autor não cita, no entanto, as dificuldades e os trajetos seguidos pelos caminhões para se chegar à Porto Velho.

A construção da BR-29 surgiu das necessidades da construção de uma rodovia que pudesse efetivamente integrar o Território Federal de Rondônia ao restante do país por via terrestre. Quando em janeiro de 1960 Paulo Leal foi convidado para compor a comissão de governadores da região Norte conhecida como "Caravana de Integração Nacional”. Aproveitouse do evento para solicitar ao Presidente da República a construção da aludida rodovia.

No dia 2 de fevereiro de 1960, após a chegada à Brasília, depois de cinco dias pela Belém Brasília, o Presidente JK convidou os governadores, membros da comissão para uma reunião, momento em que, segundo Paulo Leal, surge a oportunidade de se solicitar ao presidente, já na fase final de seu governo, a construção de uma rodovia que ligasse Rondônia ao restante do país:

Presidente, o senhor já ligou Brasília à Belém e a Porto Alegre e a está ligando à Fortaleza. Por que não completa o outro braço da cruz, construindo a rodovia BrasíliaAcre. Houve um silencio total e pesado por um curto período, quando o Presidente, no seu estilo bem característico, chamando-me pelo nome, perguntou: Uai Paulo e pode? Respondi num impulso o que o raciocínio frio não aconselharia: Pode Presidente, mas é negócio pra homem. Dando um riso aberto o Presidente retrucou, espalmando as mãos sobre a mesa: Então vai sair. (LEAL, 1986, p. 19). 
A afirmação de Paulo Leal quanto à proposta de construção da BR 029, no entanto, pode ser contestada pelas informações de Kubitscheck (2000, pp. 203-204), onde afirma que a proposta foi efetivada pelo governador do Acre, embora tenha tido apoio de Paulo Leal: "Durante a reunião, o Governador Manuel Fontenele de Castro, do Acre, fez-me uma dramática exposição sobre o isolamento em que vivia o Território, sob sua jurisdição".

Além da proposta, acompanhada de grande argumentação por parte dos governadores do Acre e, de Rondônia, o Presidente Juscelino Kubitscheck, já havia recebido informações sobre o isolamento da região por meio de uma reportagem sobre a Ferrovia Madeira Mamoré, feita por uma revista carioca, onde o jornalista Jorge Ferreira, transcreve uma carta de um seringueiro chamado Raimundo Nonato dos Santos, que vivia às margens da aludida ferrovia, dirigida a Juscelino onde expunha a vida sofrida dos sertanejos da região:

\begin{abstract}
Doutor Juscelino: Dedico esta reportagem a Vossa Excelência, a pedido de Raimundo Nonato dos Santos. Este Raimundo é um rio-grandense-do-norte, que tem sua barraca no quilómetro 172 da Estrada Madeira-Mamoré. Pai de cinco filhos esfalfa-se na sua roça de cana e macaxeira, no tempo que lhe sobra das lides de seringueiro. É uma gente encantadora, boa e trabalhadeira, Senhor presidente, que nos oferece a sua rede, a sua mesa e o seu coração num segundo. E ele, que, com a família, depende da MadeiraMamoré, define a ferrovia em poucas palavras: 'É uma porcaria. ' As míseras safras do pobre Raimundo apodreciam, por falta de transporte. Já havia perdido um filho à míngua de socorro, e o socorro só poderá vir pela Madeira-Mamoré. 'Diga pro Presidente JK para olhar um pouco por nós' - foi o que me pediu (KUBITSCHECH, 2000, p. 306).
\end{abstract}

Acordado a construção da BR-29, que já era um projeto antigo do Governo Federal, inclusive com um pequeno trecho construído dentro do Território de Rondônia (São PedroAriquemes), chegam à Porto Velho cinco dias após o deferimento do Presidente Juscelino, o chefe do Primeiro Distrito Rodoviário Nacional, sediado em Manaus, Deodônio Albuquerque.

Segundo Leal (1986, p. 30.), visando traçar estratégias para dar início as obras da BR-29, no dia 14 de fevereiro chega à Porto Velho o engenheiro Thomaz Lariez Landau, assessor da chefia nacional do DNER. No encontro entre Deodônio Albuquerque com Thomaz Landaus estabeleceu-se o primeiro plano de trabalho que se resumiria nas seguintes obras prioritárias:

- $\quad$ Melhoria dos trechos já existentes entre Cuiabá e Porto Velho;

- $\quad$ Prosseguimento da construção do trecho Abunã à capital acreana;

- Reconhecimento do trecho entre Ariquemes, Vila de Rondônia (atual Ji Paraná), e Vilhena;

- Início do desmatamento a partir do Rio Branco afluente do rio Jamari, em direção à Vilhena, e de Vilhena em sentido contrário;

- Melhoria e ampliação do campos de pouso de Nova Vida, Vila de Rondônia e Pimenta Bueno, adaptando-os para operação dos aviões DC-3.

A partir deste momento iniciam-se os trabalhos de construção da rodovia, como projeto do Governo Federal por intermédio do DNER. Por questões logísticas, criou-se a Comissão Especial de Construção, subordinada à Direção do DNER, sediada em Cuiabá.

Para que a missão de construção da nova rodovia ocorresse em conformidade com os anseios presidenciais, ou seja, em menos de um ano, o DNER teve que fugir dos métodos tradicionais, agilizando os processos de concorrência, reduzindo os prazos para contratações, assim diminuindo o tempo de tomada de decisões administrativas. No ano de 1960 o DNER era subordinado ao Ministério de Viação e Obras Públicas, o qual tinha como ministro o Almirante 
Augusto do Amaral Peixoto, naturalmente o Presidente deveria se reportar ao Ministro em caso de repassar alguma decisão ao DNER ou outro segmento da construção da rodovia. Contudo, devido a sua impetuosidade isso não ocorria, Juscelino dirigia-se diretamente ao funcionário que julgasse importante para determinada missão, quebrando assim a hierarquia administrativa (LEAL,1986).

Para dar cabo da missão de construir a BR-029, o diretor de construção do DNER, Pires de Sá, após ter sido chamado no gabinete presidencial e indagado sobre o início da construção, apresentou ao presidente Juscelino Kubitschek as condições que a seu ver seriam imprescindíveis para que a obra fosse viável. Primeiro: a alocação de recursos imediatos devido ao volume das despesas em obras daquela natureza e, segundo: um decreto presidencial que suprimisse a necessidade de concorrências públicas, visando a agilização das contratações das empreiteiras que seriam empregadas na obra.

A resposta de Juscelino foi pronta e eficaz: determinou fosse lavrado um decreto que dispensava o processo de concorrência pública e quanto aos recursos, mandou que o ministro da Fazenda Sebastião Paes de Almeida procedesse a liberação do recurso de 10,7 milhões de dólares destinados à construção da rodovia.

O Decreto presidencial n. 47.933, assinado pelo presidente Juscelino Kubitschek, determinando a construção da BR-029, foi publicado no Diário Oficial da União no dia 16 de Março de 1960.

O extenso trecho a ser construído em um curto espaço de tempo levou à contratação de várias empresas, que receberiam trechos diferentes para construção. Desta forma foram selecionadas as seguintes empresas de construção:

- Construtora Camargo Correia S.A;

- Empresa Nacional de Construções Gerais S.A;

- Construtora Triângulo S.A;

- CCBE- Companhia Construtora Brasileira de Engenharia;

- CIB- Construtora Industrial Brasileira S.A;

- Sermarso - Sergio Marques de Souza;

- Via técnica S.A.

Estas medidas foram tomadas com vistas ao início das obras que deveriam ser concluídas ainda em 1960, dividindo o traçado pelas empresas contratadas. O grande arcabouço técnico direcionado para a região envolveu um grande número de mão de obra. $\mathrm{O}$ tempo demandado para a construção, trouxe certo desenvolvimento às vilas que outrora estavam às margens do traçado da linha telegráfica de Rondon. O novo projeto de desenvolvimento nacional, traçado por Juscelino Kubitschek, responsável por modelar as primeiras formas para uma nova cultura política, muito embora alinhada ao capitalismo das grandes economias mundiais, sobretudo alinhadas aos Estados Unidos no contexto da Guerra Fria, começa aos poucos a chegar aos rincões mais distantes da abandonada Amazônia.

Além das medidas acima citadas, Juscelino determina ao SPI, que contate alguns grupos indígenas que estavam no trajeto de construção, visando implantação de projetos de extrativismo vegetal que propiciaria a manutenção econômica desses aldeamentos colhidos pela construção: 
No desdobramento do plano, o Serviço de Proteção aos índios organizaria equipes de 12 homens, tecnicamente preparados, às quais incumbiria o trabalho de atrair os pacaás-novos, os suris, os quarás e os nambiqúeras - tribos que habitavam aquelas matas - pelo mesmo sistema de integração que havia sido levado a efeito na BR-14. Nesse sentido, e tendo em vista imprimir maior eficiência à atuação do SPI, técnicos logo seriam enviados para Cuiabá, com a incumbência de construir e montar ali uma unidade radiotelegráfica, de modo que as equipes, distribuídas pela área, dispusessem de um veículo rápido de comunicação, (KUBITSCHEK, 2000, p. 310).

\section{A midia escrita, jornais e revistas que divulgaram a política desenvolvimentista de Juscelino Kubitschek}

Não ocorreu num primeiro instante, uma grande divulgação por parte da mídia nacional sobre o novo fato que iria melhorar a vida dos amazônidas, a construção da BR-029. A maioria dos diários e noticiários televisivos Brasil afora tinham, com relação a Amazônia, uma principal preocupação: divulgar as mazelas causadas pelo cenário natural naquele território, histórias de índios matando seringueiros, ou histórias de seringueiros, que em represália, matavam tribos inteiras. Noticiava-se a extração de látex e vinculavam esta extração com o Acre, no caso da exploração de cassiterita aparecia na mídia nacional o nome de Rondônia. Segundo Paulo Nunes Leal:

\footnotetext{
Perguntavam a alguns jornalistas, em tom de brincadeira, mas traduzindo um desconhecimento generalizado: "a que planeta pertencia Porto Velho". Sobre a localização do Acre, repetia-se a informação de um aviador da FAB, que dizia ficar "a cinco minutos do por do sol”. (LEAL, 1986, p. 33).
}

Todavia, por esforço do Governador do Território, Paulo Nunes Leal, a realidade no contexto das divulgações midiáticas envolvendo a construção da BR-029 e os estados da Amazônia, passaram a ter um melhor enfoque. Em Manaus e Porto Velho ocorreu uma boa cobertura por parte dos jornais locais. Em Manaus, Felipe Dahou encarregou-se de divulgar as decisões do presidente Juscelino Kubitscek. Já em Porto Velho a divulgação ficou a cargo dos jornais Alto Madeira e Guaporé. Contudo, mesmo com as divulgações na mídia local, não se mostrava na população, um quadro de euforia com a nova obra. Julgavam que por ser uma construção de fim de governo corria riscos de ser abandonada antes da conclusão. Naturalmente era uma preocupação legítima uma vez que o espaço cronológico era realmente curto. Mas por outro lado haviam os engenheiros entusiasmados do DNER e, sobretudo a figura de Pires Sá, diretor de construções deste órgão, sobre quem recaíam as decisões a serem tomadas no tocante a obra, (LEAL, 1986).

Em reunião com Pires Sá, o governador do Território de Rondônia foi bem recebido e ouviu do Diretor de Construções a seguinte preposição: “Governador vamos enfrentar o problema mais difícil de que já participei no DNER no setor de construções, dado o pouco tempo de que dispomos e o desconhecimento da região. Mas vamos cumprir as ordens do Presidente". Esta conversa foi decisiva para dirimir as dúvidas do Governador Paulo Nunes Leal (LEAL, 1986).

A partir desta conversa que teve com Pires Sá e, tendo a nítida impressão que a obra seria concluída, Paulo Leal resolveu após conversa com o Deputado Federal Aloísio Ferreira, marcar uma coletiva com a imprensa, de modo a divulgar efetivamente o início das obras. Fernando Claro de Campos, valendo-se de seu conhecimento com os jornalistas, conseguiu 
organizar uma coletiva de imprensa na Sala de Imprensa do Ministério da Fazenda, tendo comparecido os maiores jornais de São Paulo e Rio de Janeiro.

No dia 21 de fevereiro de 1960 a entrevista com Paulo Leal, Governador de Rondônia, sobre a nova face da Amazônia foi divulgada pelos seguintes meios de comunicação: O Estado de São Paulo, Folha de São Paulo, A Gazeta, e Diário do Comércio, todos de São Paulo. Publicaram também, Jornal do Brasil, Diário de Notícias e O Jornal, ambos do Rio de Janeiro.

No dia 21 de Março de 1960, a mídia internacional por meio da Revista Time publicou uma matéria intitulada: "Cortando o Centro do Brasil". A matéria tinha como pano de fundo a chegada em Porto Velho dos equipamentos e pessoal que iriam trabalhar na construção da rodovia.

A partir deste momento a utilização da mídia, tanto pelo Governo do Território Federal de Rondônia, quanto pelo próprio presidente Juscelino Kubitschek, nas ações que faziam referência à construção da BR-029 e a integração nacional foram intensificadas.

O papel da mídia foi decisivo para a construção de uma imagem positiva no aspecto da importância dos gastos públicos direcionados para Rondônia, que receberia a partir de 1960 uma rodovia capaz de escoar sua produção e, sobretudo receber mercadorias de outros estados da Federação. Rondônia estava agora atrelada ao raio de ação da nova capital nacional, Brasília.

\section{A expedição ford e a BR-029}

O final do mês de setembro marca, na região amazônica, o início do período das chuvas e, naturalmente, este fator passou a dificultar o andamento das obras de construção da rodovia. Segundo Paulo Nunes Leal:

Em fins de setembro de 1960 caíram as primeiras chuvas, indicando um início antecipado da estação denominada regionalmente "inverno", mas na realidade simplesmente a estação das aguas. Ainda com grande extensão da rodovia apenas desmatada sem qualquer serviço de terraplanagem, em certos trechos faltando até destocamento, tudo fazia supor que a implantação da BR-029 ficaria por terminar, não sendo terminada até dezembro (LEAL, 1986 p.189).

Além das dificuldades climáticas outro fator passou a dificultar a construção da rodovia: o DNER passou a atrasar o repasse de verbas às empreiteiras que trabalhavam nos trechos de construção e este fator passou a causar morosidade nos trabalhos das aludidas empresas de engenharia. Pararam de contratar trabalhadores e passaram a executar apenas serviços de maior rentabilidade com pequenas quantidades de gastos. A candidatura de Jânio Quadros à presidência, com grande aceitação popular, nas eleições de novembro de 1960 causava, para o governador de Rondônia Paulo Leal, um grande temor. Haja vista que Jânio Quadros demonstrava em seus pronunciamentos certo desprezo às obras de Juscelino Kubitschek, na Amazônia, chegando a chamar a rodovia Belém-Brasília de "Estrada das Onças" (LEAL, 1986).

Diante das dificuldades e incertezas, com poucos trechos inacabados para dar término ao empreendimento, o governador de Rondônia, resolveu criar uma situação política e midiática que pudesse forçar Juscelino Kubitschek a terminar a obra até o mês de dezembro de 1960, tal qual planejado. 
Imaginou que pudesse organizar, com patrocínio empresarial, uma caravana de veículos que trafegassem no trecho entre São Paulo e Rondônia, com a devida cobertura da mídia nacional, de forma a demonstrar tanto as dificuldades de travessia nos trechos inacabados, quanto à importância da agilização no término da mesma.

Consultando seus assessores políticos mais próximos e buscando o aval do Deputado Federal Aloísio Ferreira, que havia sido o primeiro governador do Território, Paulo Leal recebeu o devido apoio à sua empresa.

A Ford já havia vendido vários automóveis e caminhões por regiões periféricas do país, seu interesse por expansão mercantil era visível mesmo em suas propagandas. Dessa forma representava, para o governador de Rondônia, uma possível parceria no projeto de construção de uma caravana que iria cruzar o interior do Brasil, sendo acompanhada pela mídia nacional, fomentando a conclusão da BR-29.

Os contatos prévios de Paulo Leal com a Ford ocorreram por intermédio do gestor de relações públicas daquela empresa Osvaldo Silva.

A proposta do governador de Rondônia possuía vantagens para a Ford e para o próprio Território de Rondônia, uma vez que divulgaria a imagem de pioneirismo e robustez dos veículos fabricados pela Ford, ao passo que comoveriam a opinião pública sobre a necessidade imediata de conclusão por parte do Governo Federal, da rodovia.

A proposta era a seguinte: A Ford organizaria uma caravana composta apenas de veículos dessa marca, que se chamaria "Caravana Ford", visando realizar uma viagem de São Paulo à cidade de Porto Velho, passando pela inconclusa BR-29.

Em contrapartida, o Território de Rondônia cederia pessoal para condução dos veículos (caminhões) e proveria a alimentação durante o trajeto. O governo do Território compraria da Ford, três caminhões para a Caravana. Para que houvesse justificativa para a exclusividade na compra de três caminhões da Ford, esta doaria ao Território de Rondônia, um caminhão que se somaria aos demais na jornada da Caravana Ford. A contratação de jornalistas, fotógrafos, e todo suporte da mídia ficaria a cargo da Ford, inclusive a disponibilização de um mecânico que acompanharia a expedição (LEAL, 1986).

Os contatos feitos com a Ford por intermédio do senhor Oswaldo Silva foram extremamente frutíferos, marcou-se uma reunião formal para o dia 20 de outubro de 1960, com a diretoria da Ford, visando acertar os últimos detalhes para a configuração da Caravana Ford.

Contudo, a notícia da reunião vazou para a imprensa paulista e, no dia 12 de outubro de 1960 o Jornal O Estado de São Paulo já antecipava a divulgação da ilustre reunião entre membros do Governo de Rondônia e diretores da Ford:

É esperado em São Paulo, na próxima semana, o governador do Território Federal de Rondônia, Coronel Paulo Nunes Leal, que aqui vem acertar pormenores relativos à partida da caravana pioneira de caminhões e jipes que farão o trajeto da estrada AcreBrasília a partir do dia 20. (O ESTADO DE SÃO PAULO, 12 de Outubro de 1960, apud LEAL, 1986, p. 194).

A partir deste momento a participação da mídia, sobretudo escrita, mas também falada, foi fundamental no trabalho de divulgação da Caravana Ford, citando todos os passos e dificuldades sofridas pelo grupo. Isso se deve não somente ao interesse do Governo de Rondônia na divulgação dos fatos, forçando o DNER a terminar as obras mas, sobretudo pelo fato de haverem jornalistas compondo a Caravana Ford, na condição de correspondentes de jornais de grande divulgação. 
A reunião que estava prevista para o dia 20 de outubro na cidade de São Paulo, ocorreu normalmente. Após uma hora de discussões sobre os pros e contras, a proposta de Paulo Leal estava aceita, a Caravana Ford já era uma realidade.

Dia 21 de outubro a imprensa de São Paulo divulgou com grande enfoque a assinatura do convênio entre a Empresa Ford e o Governo do Território Federal de Rondônia, por intermédio de seu governador Paulo Nunes Leal. Na cerimônia que marcou o acordo entra a Ford e o Território de Rondônia estavam presentes os representantes da Ford, jornalistas, empresário e, de Rondônia, o Governador Paulo Leal e o Deputado Federal por Rondônia Aloísio Ferreira, que apoiava a estratégia de Paulo Leal por entender as dificuldades na área de transporte sofridas pelo Território de Rondônia, uma vez que já havia sido, também, governador do mesmo.

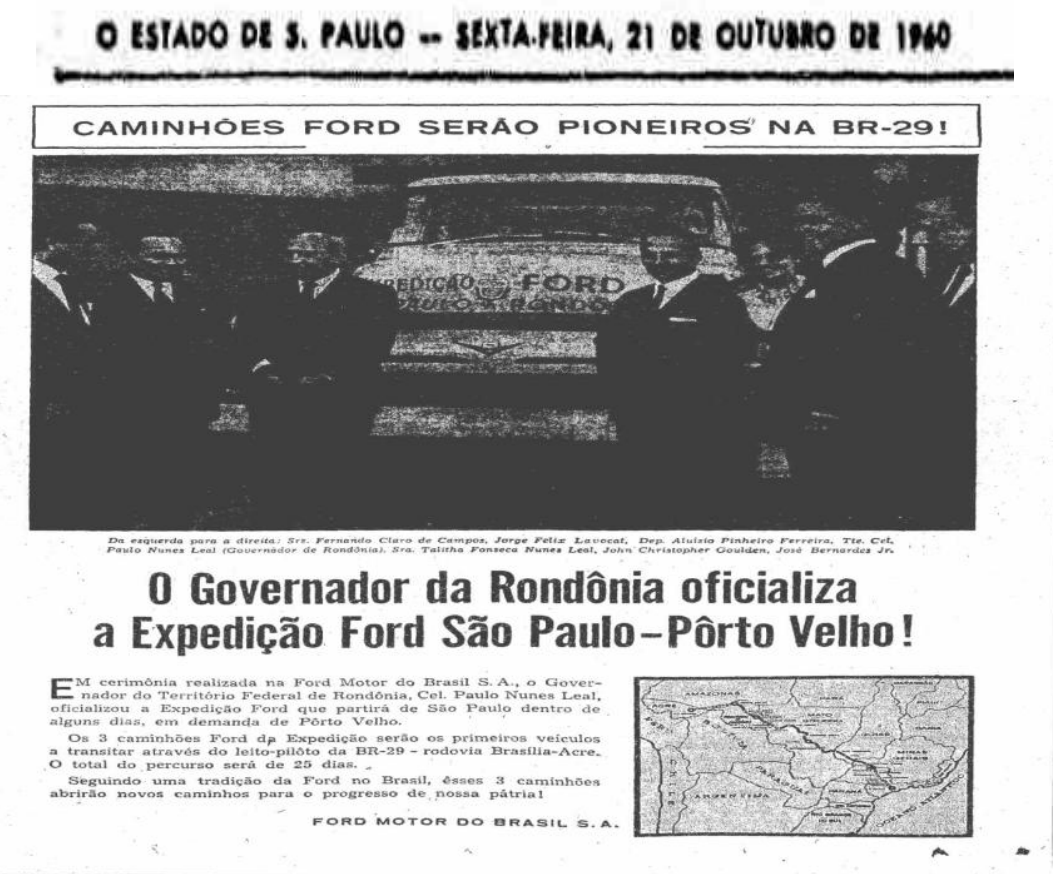

Fonte: O Estado de São Paulo

Em Porto Velho, por volta do dia 23, sabendo das notícias que circulavam o país, membros da Comissão Especial de Construção da BR-29, foram à casa do Governador, tentando demove-lo da ideia de dar continuidade àquele projeto. Como Paulo Leal encontrava-se em São Paulo, pediram que sua esposa entrasse em contato com o mesmo para informa-lo da impossibilidade de concluir os trabalhos no tempo previsto.

No dia 26 de outubro a Folha de São Paulo já divulgava a partida da Caravana Ford, com a seguinte matéria:

Partirá depois de amanhã, desta capital, com destino à capital do Território Federal de Rondônia, uma caravana de 8 viaturas - 7 caminhões Ford e um jipe - que pela primeira vez na história dos transportes nacionais, ligará por terra as duas cidades, através da rodovia BR-29, Brasília-Acre, que constitui uma das mais extensas estradas de rodagem do plano rodoviário do presidente Juscelino Kubitschek (JORNAL FOLHA DE SÃO PAULO 26 de outubro de 1960, apud LEAL, 1986. p.196).

Dia 28 de outubro, após todos os preparativos a Comissão Ford organiza-se para iniciar a grande viajem. A folha de São Paulo ilustra seu jornal com uma fotografia do antigo 
veículo Ford pertencente ao Marechal Rondon em 1926, dando com isso a ideia de que a marca Ford era utilizada pelos pioneiros e desbravadores.

A Caravana Ford saiu de São Paulo às 15h30min do dia 28 de outubro de 1960. Estimavam chegar a Porto Velho nos primeiros dias do mês de dezembro do mesmo ano, se o DNER conseguisse abrir caminho entre Pimenta Bueno e Vila de Rondônia, atual Ji-Paraná.

A equipe era assim formada: Chefe: Antônio Brasileiro, Representante da Ford do Brasil: Silvio Fornasaro, Médico: Dr. Carlos Toledo Fleury, Mecânico da Ford: Sergio Zalawska, Naturalista: Cel. Moacir Alvarenga, Representante da Folha de São Paulo: Dr. Hugo Penteado, Representante da Gazeta de São Paulo: Alvaro da Costa, Representante do jornal Estado de São Paulo: Wlado Herzog, Cinegrafista: Nestor Marques. Pessoal do Território Federal de Rondônia: Subchefe da Caravana: Eduardo Lima e Silva, Motoristas: José Araújo, Antônio Geraldo Aguiar, Cordiel Firmino de Souza, Milton Luíz dos Santos, Antônio Costa Pereira, Auxiliar de motorista: Benedito Cardoso.

Percebe-se que a Caravana Ford, tinha acima de tudo um cunho jornalístico e midiático, senão vejamos: quando se quantifica os membros da comissão com funções técnicas, observa-se que a maioria era da imprensa, sendo três jornalistas e um cinegrafista. A função destes correspondentes era informar "ipses literi” cada passo da caravana aos jornais que os havia contratado, visto que as informações contribuiriam para uma visão global do cenário político do governo de Juscelino Kubitschek, no quesito “obras públicas” além de mostrar à opinião pública o cenário exótico do Oeste brasileiro sendo desbravado por um comboio de caminhões.

Outro fator importante das matérias enviadas pelos correspondentes dos jornais que compunham a Caravana Ford era gerar uma opinião pública favorável à conclusão das obras por parte do Governo Federal por meio do DNER.

Passada a primeira fase de divulgação dos preparativos da Caravana Ford, com a chegada do Governador de Rondônia a São Paulo e da saída da expedição rumo à Oeste, as noticias, agora, chegam à São Paulo vindas da cidade de Cuiabá. A Caravana, no dia 2 de novembro às 16h30min, onde permaneceram três dias para revisão das viaturas (LEAL, 1986).

Por intermédio do correspondente de A Gazeta, que acompanhava a Caravana Ford, Álvaro Costa, o aludido periódico divulgou no dia 5 de novembro a seguinte notícia:

Cuiabá, 4 (De Álvaro Costa, enviado de A Gazeta). - Chegamos à Cuiabá, onde estamos alojados no melhor hotel desta cidade, cujas acomodações haviam sido previamente reservadas. Este detalhe é importante, pois os hotéis e pensões desta antiga capital de Mato Grosso andam sempre cheios, desde que foi iniciada a construção da Rodovia Acre-Brasília, a BR-29. É grande o movimento, principalmente de pessoas interessadas em negócios de terras, lotes de gado etc. A construção da BR-29 desta cidade para Porto Velho está despertando grande interesse para a região noroeste de Mato Grosso, na divisa com o Território de Rondônia, na Serra dos Parecis. Assim, pois, aquele que chega à Cuiabá sem ter reservado acomodações, dificilmente encontra lugar nos hotéis e pensões. (JORNAL A GAZETA, 1960 apud LEAL, 1986, p. 203).

Observa-se que a veiculação dessa matéria possuía um grande teor de propaganda desenvolvimentista, que chamava a atenção tanto para as melhorias na infraestrutura da região, que naturalmente servia como apelo para investimentos para quem, por ventura, estivesse interessado em adquirir terras e gado na região do Mato Grosso. 
Dando sequencia à viagem, a chegada da Caravana Ford em Vilhena ocorre no dia 12 de novembro de 1960, depois de atravessar, no estado do Mato Grosso um longo trecho semidesértico permeado por areais densos que dificultaram o percurso.

Álvaro Costa, já em Vilhena, envia para A Gazeta, outra matéria que foi publicada em 19 de novembro de 1960, dando conta de que Vilhena, outrora apenas um posto telegráfico da Comissão Rondon cercado por poucas casas de funcionários, era agora um imenso canteiro de obras da empresa Camargo Correa.

No dia 20 de novembro de 1960, após percorrer 160 quilômetros de rodovia inacabada, a Caravana Ford chega à Pimenta Bueno. Neste ponto a viagem é interrompida, pois o trecho entre Pimenta Bueno e Vila Rondônia ainda estava inacabada. Faltavam trechos de floresta ainda a serem derrubados, havia lugares sem encascalhamento, etc.

Segundo Leal, (1986), novamente o jornalista Álvaro Costa envia notícia ao jornal que representava A Gazeta, que será divulgada em 28 de novembro. Esta será a ultima notícia de jornais de São Paulo, falando sobre a BR-29, até sua chegada à Porto Velho.

A matéria de Álvaro Costa em Pimenta Bueno fazia o seguinte comentário:

\begin{abstract}
Pimenta Bueno, Rondônia (De Alvaro Costa, enviado especial junto a Expedição Ford) - Foi interrompida nesta cidade, pelo menos por uns 10 dias, o avanço da expedição Ford através da rodovia Brasília-Acre. Aliás nesta altura, não passa de eufemismo falar em rodovia, pois o que existe no traçado da estrada é uma simples faixa aberta no meio da mata, sequer nivelada e na qual a lama proveniente das chuvas constantes forma obstáculos intransponíveis. Depois de nossa chegada a esta localidade e de uma indecisão sobre a movimentação da caravana, ficou resolvido interromper a marcha. O Sr. Antonio Brasileiro, chefe da expedição Ford, comunicou-se pelo rádio com o coronel Paulo Leal, recebendo instruções para que o pessoal da caravana seguisse por via aérea para Porto Velho, capital do Território de Rondônia, bem distante ainda do ponto atingido em nosso avanço. Em Porto Velho, os integrantes da expedição aguardarão a abertura de um trecho de 53 quilômetros de mata, a fim de permitir a ligação entre Pimenta Bueno e a capital do Território. Esse trecho, consoante ainda as informações prestadas pelos encarregados da construção, já está quase inteiramente aberto. As obras, porém, ainda demorarão de 8 a 10 dias, motivo pelo qual decidiu-se que a caravana somente reiniciará sua marcha no próximo dia 5 de dezembro (JORNAL A GAZETA, 1960 apud LEAL, 1986, p. 219).
\end{abstract}

Após a permissão do governador Paulo Leal, para que os membros da caravana viessem a Porto Velho, houve uma reconfiguração no grupo. Os Jornalistas e técnicos retornaram aos seus estados de origem, alguns motoristas foram substituídos e a chefia da Caravana Ford foi substituída. O Sr Antônio Brasileiro deixou a caravana, passando o comando para Eduardo de Lima e Silva, o Dudu, que era chefe da equipe de motoristas.

Como a sequencia da viagem perecia ser inevitável, havendo ou não estrada, a Comissão Especial de Construção da Br-29, que era um órgão do Governo Federal e coordenava as ações do DNER e das empreiteiras, tratou de acelerar o processo de conclusão dos trechos que ainda faltavam ser construídos, visando não acarretar desgaste à imagem do presidente Juscelino Kubitschek, uma vez que a Caravana Ford estava sendo observada pela mídia escrita e falada de todo país.

Entre os dias 20 e 30 de novembro de 1960 a caravana Ford ficou estacionada em Pimenta Bueno. A viagem foi retomada em 30 de novembro com inúmeras dificuldades, tanto na travessia do rio Comemoração quando no trajeto até Vila Rondônia, aonde chegou em 15 de dezembro, conforme matéria veiculada no jornal Alto Madeira, um periódico de Porto Velho. 


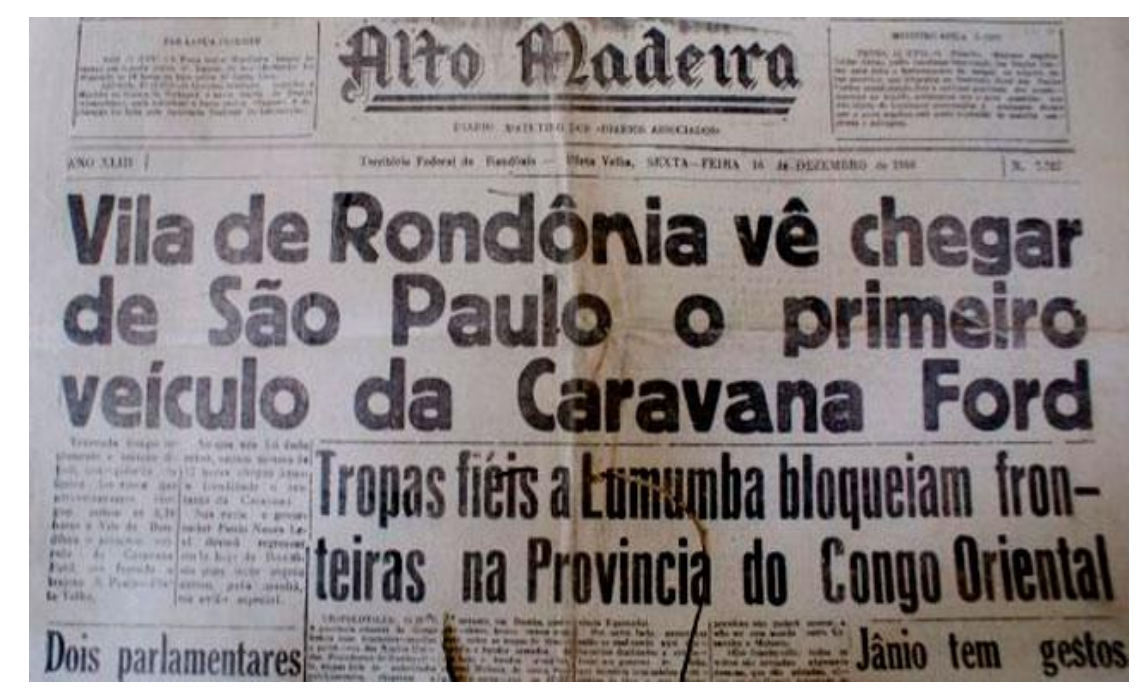

FONTE: Blog Gente de Opinião.

Conforme Leal (1986), no dia 27 de dezembro de 1960, o ambiente na Capital de Rondônia era de euforia. Os caminhões da caravana haviam sido avistados por aviões do aeroclube de Porto Velho entre Ariquemes e o rio Preto.

No dia seguinte os jornais de Porto Velho já divulgam a chegada da Caravana Ford. O jornal O Guaporé faz circular a seguinte notícia:

Porto Velho receberá hoje a Caravana dos caminhões que partiu de São Paulo com destino a nossa capital. Cortaram as pistas asfaltadas do estado bandeirante, entraram pelas estradas batidas do Triângulo Mineiro, alcançaram Goiás, com seus campos imensos, atravessaram as fronteiras de Mato Grosso no Alto Araguaia, atingiram Cuiabá e pelo leito virgem da BR-29 chegaram ao território, em demanda de nossa cidade. Trazem os caravaneiros a flama sagrada dos Bandeirantes no seu ardor cívico, na sua coragem, no desejo de ver o Brasil cada vez maior. (O GUAPORÉ, 1960 apud LEAL, 1986, p. 243).

É explícito o conteúdo nacionalista envolvido nesta matéria, dando clara ênfase à integração nacional que, além de ser um dos princípios que haviam fomentado a construção da BR-29, evidenciava a aludida rodovia no cenário geográfico do país.

Finalmente no dia 13 de janeiro de 1961, o presidente Juscelino Kubitschek, aproveitando compromisso que tinha na cidade de Cuiabá, aproveitou para, em uma cerimônia simples, entregar ao tráfego a BR-29, com um trecho construído de 3.306 quilômetros.

\section{Considerações finais}

A conclusão da BR-29, no prazo combinado entre Juscelino Kubitschek e Paulo Leal, estava, no final de 1960, ficando inviável. Primeiramente pela escassez de recursos do DNER para o pagamento das empreiteiras envolvidas na construção, em segundo lugar as condições climáticas da região não favoreciam a fluidez das obras por conta das constantes chuvas.

A crise do dólar e o rompimento de JK com o FMI em junho de 1959, haviam gerado certo desconforto econômico, que certamente refletiram no repasse de verbas para a construção da BR-29. No campo político Juscelino Kubitschek lança oficialmente em outubro de 1959 a candidatura do general Lott à presidência (PENNA, 1999). 
Para Juscelino Kubitschek as pressões políticas por parte do governador do Território de Rondônia, no sentido da conclusão das obras em prazo hábil, não ofereciam grande apelo, visto que o presidente não vislumbrava a possibilidade de reeleição, devido a lei eleitoral da época. Ao que parece os projetos de reeleição de Juscelino Kubitschek eram para 1965.

Dessa forma, pressões partidárias e de pequenos grupos locais não forçariam JK a despender verbas para o termino de uma rodovia que não lhe geraria opinião pública vantajosa a médio prazo, ou seja, para as eleições de 1965.

Entretanto, para Rondônia a conclusão da aludida rodovia era vital, pelos motivos já expostos. Em âmbito nacional o único representante político do Território de Rondônia era o exgovernador Aloísio Ferreira, que neste momento era deputado federal.

Consultando Aloísio Ferreira, Paulo Leal resolve apelar para a opinião pública de âmbito nacional. Procura um parceiro na iniciativa privada, a empresa Ford, e resolve criar um fato que chamaria a atenção de todos quantos fossem atingidos pela força da mídia escrita, por meio dos jornais de grande circulação, no caso: A Gazeta, A Folha de São Paulo e O Estado de São Paulo, além dos jornais de veiculação em Rondônia: O Guaporé e o Alto Madeira.

A formação da Caravana Ford, acompanhada de Jornalistas que faziam a cobertura da viagem entre São Paulo e Rondônia, com matérias diárias nos jornais que representavam, terminou criando uma opinião pública que favoreceu a tomada de atitude por parte do Governo Federal no sentido de concluir a construção da BR-29 no período combinado.

Ao que se observa, Juscelino Kubitschek temia que a veiculação de notícias diárias em jornais importantes, mostrando o sofrimento dos membros da Caravana Ford, ao longo de uma estrada que ele havia iniciado e prometera sua conclusão ainda em 1960, poderia gerar uma imagem negativa que pudesse influenciar sua imagem política até as eleições de 1965.

Enfatiza-se que a Caravana Ford juntamente com as ações da mídia escrita foram fatores eficazes para o convencimento do Governo Federal na conclusão das obras da BR-29 no início do ano de 1961.

\section{Referências}

FAUSTO, Boris. História concisa do Brasil. São Paulo: Edusp, 2001.

KUBITSCHEK, Juscelino. Porque construí Brasília. Brasília: Senado Federal, Conselho Editorial, 2000.

LIMA, Abnael Machado de. 50 Anos da Caravana Ford - III (Os Heróis Esquecidos). Disponível em: http://www.gentedeopiniao.com.br. Acesso em 02 de dezembro de 2013.

MCLUHAN, Marshall. Os meios de comunicação como extensões do homem. São Paulo: Editora Cultrix, 1969

LEAL, Paulo Nunes. O Outro Braço da Cruz. 2 ed. [S.n.], 1986.

PENNA, Lincoln de Abreu. República brasileira, Rio de Janeiro: Nova Fronteira, 1999.

SANTAELlA, Lúcia. O que é semiótica. São Paulo: Brasiliense, 1983. 


\section{Çairé: cultura amazônica reinventada pelo mercado para a mídia}

Raimunda Adriana Maia Costa (UFOPA)

Tânia Suely Azevedo Brasileiro (UFOPA)

\section{Introdução}

A Amazônia como um todo, em especial a porção brasileira, ou Amazônia Legal, é caracterizada por sua imponência territorial, por sua vasta biodiversidade e riqueza de recursos naturais. Esta, porém representa, na maioria das vezes, uma visão estrangeira, externa e por vezes até folclórica do território em questão. Dizemos isto por sentirmo-nos incomodadas, por olharmos a Amazônia de dentro e por dentro, mas nem sempre conseguirmos tecer as argumentações suficientes para justificar este incomodo, já que este folclorismo é a versão que, também, nos acompanhou ao longo de nossa vida acadêmica e que se fixou a partir dos insistentes discursos veiculados pelo mass media.

A Amazônia abrange cerca de 7 milhões de $\mathrm{Km}^{2}$, dos quais 5,5 milhões de $\mathrm{Km}^{2}$ são cobertos por uma densa floresta tropical de clima úmido e quente que abrange nove países da América Latina, sendo: Venezuela, Equador, Bolívia, Guiana Francesa, Suriname, Guiana, Peru, Colômbia e o Brasil; que absorve $60 \%$ de toda a composição geográfica. Este percentual, situado em território nacional, corresponde ao que se chama de Amazônia Legal e é composta pelos Estados do Amapá, Rondônia, Tocantins, Roraima, Maranhão, Mato Grosso (exceto o pantanal), Amazonas e Pará. Conforme a figura 1.

Figura 1: Mapa da Amazônia Legal

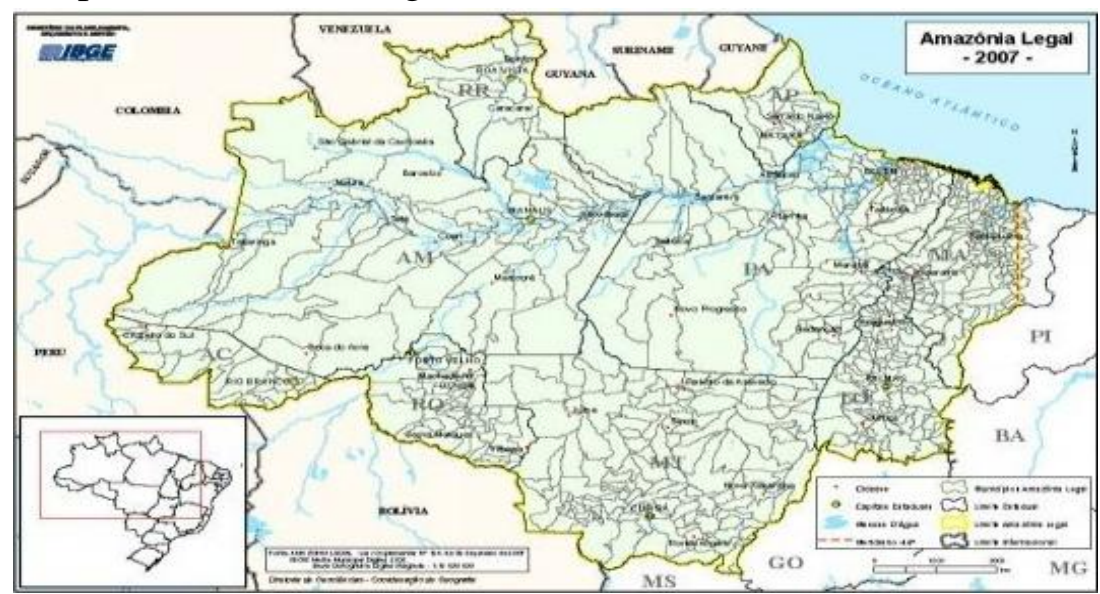

Fonte: IBGE (2010)

Em terras brasileiras, a Amazônia compõe 49,9\% da área geográfica nacional, incorporando parte das Regiões Nordeste, Centro-Oeste e Norte integralmente. Longe de reavivarmos o clichê de que "A Amazônia é o pulmão do mundo", sabe-se, em função das 
alterações climáticas planetárias, da crescente importância da Região Amazônica para o equilíbrio climático e ambiental do planeta. Nela fixam-se grandes proporções de carbono e liberam-se toneladas de água para a atmosfera. Os rios da Amazônia respondem por 20\% de toda a água doce fluvial carreada e incorporada pelos oceanos. A Região é uma rica fonte de matéria-prima mineral, medicinal, florestal, alimentar e energética, dada as condições climáticas, geográficas, de solo e relevo privilegiados.

A Amazônia encontra-se entre as três maiores florestas tropicais do mundo e abriga um dos mais ricos, complexos e delicados ecossistemas do planeta. Neste bioma não podemos descartar a importância de nenhum dos seus elementos (fauna, flora, solos, clima) sob pena de ignorarmos suas características mais fundamentais. Sendo o maior bioma do país a Amazônia passou a figurar, efetivamente, no processo de desenvolvimento nacional após a Segunda Guerra Mundial e mais notadamente com a implantação de Grandes Projetos, entre eles citamos: Projeto Jari, Projeto Manganês, Projeto Grande Carajás, Projeto Zona Franca de Manaus, Projeto ALBRÁS-ALUNORTE, Projeto ALUMAR, Projeto Trombetas, Projeto JurutiALCOA, Projeto de Colonização da Transamazônica, Projeto Urucum-PETROBRÁS e os Projetos de aproveitamento energético com a construção das Hidrelétricas de Tucuruí, Samuel, Balbina, Jirau e Belo Monte. Segundo Hage e Barros (2010, p. 351):

A implantação de projetos de colonização e assentamentos agrícolas, fazendas de gado,
exploração madeireira, garimpagem, construção de barragens e hidrelétricas,
mineração, construção de rodovias e ferrovias, distritos industriais, etc, têm provocado
o deslocamento da fronteira humana, econômica e social do centro-sul do país em
direção à Amazônia.

Para Lúcio Flávio Pinto (2009), todos os grandes projetos econômicos implantados, e outros intentos, abriram imensas clareiras na floresta amazônica, e nela instalaram o capitalismo mais moderno que se dispunha. Sem grandes menções aos prejuízos geopolíticos e econômicos nossas maiores preocupações são com os impactos socioculturais provocados por estes empreendimentos, visto que, além de toda esta riqueza natural, abriga-se neste nicho ecológico expressiva quantidade e diversidade de povos indígenas e de populações tradicionais onde destacamos: quilombolas, caboclos, ribeirinhos, castanheiros, seringueiros, pescadores e tantos outros que habitam este espaço, que se tornou uma zona econômica estratégica e alvo de múltiplos interesses internacionais, e lhe conferem grande diversidade sociocultural. Acreditamos, ainda, que as clareiras mencionadas por Pinto (op. cit) não se restringem somente aos vácuos da degradação ambiental, impostos pelas atividades madeireiras, minerais e agropecuárias, mas incluem também as clareiras culturais que, fatalmente, provocam fissuras na identidade amazônida pela hibridização das culturas que se agregam neste território de interesse mundial.

Face ao exposto, e como ilustrações prévias, não poderíamos deixar de mencionar as grandes contradições que se apresentam, pois, sendo a maior região em área territorial, é a menor em densidade demográfica do Brasil (IBGE, 2014); abrigando o maior pólo produtivo de eletro-eletrônicos (Zona Franca de Manaus), este desenvolvimento não representa melhorias nos índices de qualidade de vida, acesso às tecnologias e de inclusão digital (NERI, 2013); sendo a região mais rica em recursos naturais, é a que apresenta sua totalidade de Estados entre os 16 com menor índice de desenvolvimento humano-IDH (PNUD, 2010) e menor PIB regional.

A partir das evidentes contradições apresentadas, acreditamos que as questões ambientais não podem ser o eixo central da constituição de políticas públicas para a Região, 
antes disto, estas devem ser vislumbradas em função dos Seres Humanos, dos povos amazônidas, de suas necessidades e anseios, tendo a preservação da Cultura e a garantia da Educação como objetivos fundamentais para a sustentabilidade dos diversos povos que nela habitam.

\begin{abstract}
A Amazônia hoje, como natureza, sociedade e cultura, é também, o resultado do processo histórico de expansão do modo de produção capitalista e das suas formas de intervenção: mercantilismo, colonialismo, imperialismo, internacionalismo e globalismo. [...] A dimensão dos conflitos das sociedades amazônicas com o capitalismo supera as possibilidades de compreensão de quaisquer desses campos teóricos isolados (NOGUEIRA, 2008, p. 23).
\end{abstract}

Situada a Amazônia, passamos a pensar nos eventos históricos que constituem este cenário. Mas antes, nos questionamos o que são eventos históricos? O que os caracteriza? Seriam o mesmo que fatos históricos? Seriam os eventos, fatos e acontecimentos nomes diferentes para um mesmo significado? Das muitas perguntas, com poucas respostas, nos limitamos a aproximar o sentido de eventos históricos como sinônimo de acontecimentos históricos, pois chegamos ao consenso de que ambos dizem respeito a algo que se passou, que tem um lastro existencial por seu compromisso e fidelidade com a realidade, trata-se daquilo que tomamos conhecimento de sua existência através dos indícios histórico-culturais deixados e dos testemunhos daquel@s que, de alguma forma, compartilharam do fenômeno estudado, e que podem ser cientificamente comprovados. Este conjunto de argumentos, contudo, não se aplicaria ao fato, pois este é uma representação, é o que se diz, a respeito de determinados acontecimentos, são impressões, opiniões cujas narrativas, carregadas de subjetividades criam significados quando desaguadas pela nova Cultura Midiática, com o auxílio das Tecnologias da Informação e Comunicação (TIC), na sociedade.

\footnotetext{
As novas tecnologias da informação e comunicação, caracterizadas como midiáticas, são, portanto, mais do que simples suportes. Elas interferem em nosso modo de pensar, sentir, agir, de nos relacionarmos socialmente e adquirirmos conhecimentos. Criam uma nova cultura e um novo modelo de sociedade (KENSKI, 2003, p. 23-24).
}

Assim, não podemos negar que a cultura sempre representou fator de diferenciação no desenvolvimento dos povos. Tanto é que cultura de maneira geral é entendida como o "Conjunto de costumes predominantes num grupo ou classe social. Tudo o que caracteriza uma sociedade qualquer, compreendendo sua linguagem, suas técnicas, artefatos, alimentos, costumes, mitos, padrões estéticos e éticos" (AULETE, 2011, p. 425) e cultura de massa dizemse dos "Conjuntos de bens culturais produzidos pela indústria cultural, e os costumes, valores, práticas etc. de largas parcelas da população, difundidos graças aos meios de comunicação de massa" (op. cit.). Assim, a Cultura Digital e a Cibercultura (LEVY, 1999) representam, junto com os meios de comunicação de massa, e dentre alguns se destacam jornais impressos, rádio e TV, os principais espaços de intervenção da comunicação de larga escala. Com efeito, nos meios de comunicação de massa são incluídos todos os tipos de mídias orais, escritas e impressas de grande circulação e de fácil acesso, utilizadas na disseminação de mensagens indiscriminadamente a uma expressiva parcela populacional.

Desta forma, a mídia dá sentido, cede o sopro da existência aos fatos pela construção das narrativas ideológicas que disponibiliza. Com essa afirmação queremos dizer que a mídia decide se algo é evento ou um fato, se existiu de fato ou não, pois na medida em que o torna 
notícia e lhe atribui maior importância, o fato ocorrido vira um acontecimento/evento, reduz sua efemeridade e cria contornos históricos situados no tempo e espaço em que se realizam, através de seus indícios.

Sendo os fatos títulos atribuídos às relações espaço-temporais do Ser Humano com sua realidade, sem este vínculo com a realidade um fato jamais poderia ser elevado à condição de evento histórico, pois seu rastro de fidelidade com o mundo seria diluído na própria realidade. Neste sentido, o trabalho do pesquisador, historiador, educador frente à cultura do seu tempo inclui, sobretudo, questionar-se sobre a veracidade dos fatos a partir de seus indícios aparentes e latentes, pressupõe perguntar ao tempo e aos espaços: quando, onde, como e porquê aconteceu determinado evento; imprimir sentido às suas inferências a partir de sua bagagem teórica e socializar suas descobertas. Sobre este assunto, segundo Ricouer (2007, p. 190), “O acontecimento, em seu sentido mais primitivo é aquilo sobre o que alguém dá testemunho. É o emblema de todas as coisas passadas (praeterita). Mas o dito do dizer do testemunho é..." somente um fato que aconteceu, é pretérito.

Não podemos ignorar que tanto os eventos quanto os fatos, sejam eles políticos, econômicos, sociais ou culturais, com o avanço das TIC, estão sujeitos a formatos midiáticos que outrora não estávamos habituad@s a ver. Neste sentido, também os acontecimentos, segundo (VEYNE, 1998), não representam as totalidades, mas as porções nucleares de relações humanas. Completando esta ideia, segundo MacLuhan, apud Zacharias e Costa (1995, p.19), "por conta dos efeitos das telecomunicações, as culturas locais são dissolvidas nas culturas mundiais; neste sentido, os valores, os significados familiares, antes garantidos, hoje se configuram como expressões de relações distantes localmente situadas".

Como bem se vê em nada é fácil pensar a Amazônia a partir da Amazônia, muito menos seus eventos históricos, pois neste exercício não estão presentes somente os olhares das pesquisadoras (neutros ou não), mas, sobretudo, as representações sociais e culturais de uma típica cabocla amazônida e daquela que, encantada pelo suave movimento dos banzeiros, deixou-se apaixonar por um pedacinho da Amazônia paraense: Alter-do-Chão - em Santarém. Alter-do-Chão é uma vila situada na margem direita do Rio Tapajós, a $34 \mathrm{Km}$ do centro urbano do Município de Santarém, com acesso tanto por via fluvial, quanto pela Rodovia Estadual Everaldo Martins - PA457. Um belíssimo pedaço da Amazônia, conforme se vê na figura 2. 


\section{Figura 2 - Vista área da Vila Balneária de Alter-do-Chão}

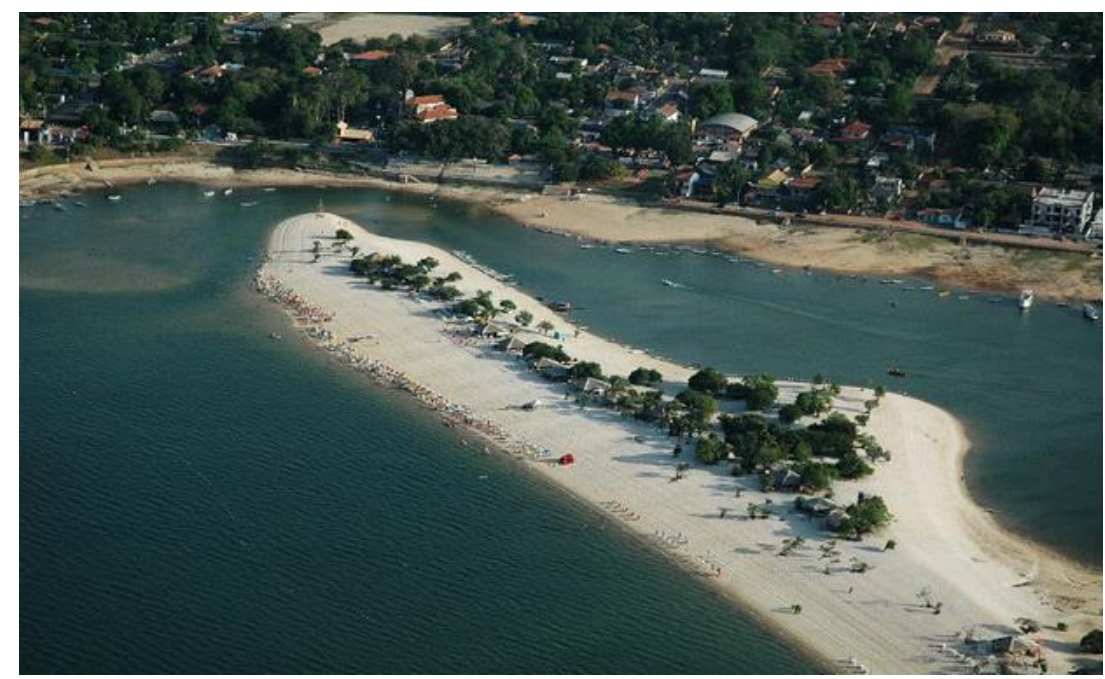

Fonte: Guia Quatro Rodas. Disponível em: http://viajeaqui.abril.com.br/cidades/brpa-alter-do-chao/fotos

O especial interesse por Alter-do-Chão, e seu resgate neste trabalho, justifica-se pelo fato de que este vilarejo realiza anualmente um dos grandes eventos histórico-culturais do Estado do Pará - o Çairé. Temos na literatura e nos relatos mais antigos que, nos intentos de catequizar os Índios Boraris ${ }^{1}$, os Padres Jesuítas inseriram símbolos religiosos aos rituais indígenas.

O ritual (dança, bailado e devoção) ganhou os confins da Amazônia levado pelas mãos dos catequistas-colonizadores, mas, já no final do século passado, havia desaparecido na maioria dos lugares onde antes tinha sido vigoroso: sucumbiu às mudanças nas formas de cristianização e a novas culturas que surgiram com as transformações sociais e políticas da região (NOGUEIRA, 2008. p. 137-138).

Nogueira (2008), recorrendo aos estudos de Santiago (1996), afirma que o primeiro registro histórico da Festa do Çairé data de 1762, em uma descrição atribuída ao Monge João S. de José de Queiroz, na época Bispo da Diocese do Pará, onde "informa sobre uma "dança de índias" e o objeto para o qual se voltava o cortejo, um semicírculo ou um meio arco de madeira, conduzido por uma índia que comandava a dança em círculo alargando ou recolhendo a roda conforme ganhavam mais espaço no terreiro" (SANTIAGO apud NOGUEIRA, 2008, p. 138). Os Padres Jesuítas logo trataram de atribuir aos elementos da Festa um caráter religioso aos festejos considerados profanos, onde foi inserido ao arco três cruzes, duas na base e uma posta logo acima, representando, segundo o catolicismo: Pai (Deus), Filho (Jesus) e O Espírito Santo (Santíssima Trinhdade); a índia responsável pela condução do Çairé, símbolo máximo da festa, é a chamada Saraipora. Segundo a tradição, a festa se realiza anualmente em uma mistura do profano, expresso no canto, na dança e na bebedeira; com o religioso percebido nas procissões, ladainhas e, principalmente, no Çairé. Conforme se observa seus principais símbolos na figura 3.

\footnotetext{
${ }^{1}$ Borari era como denominava-se a tribo indígena que habitava o território que hoje compreende a Vila balneária de Alter-do-Chão.
} 


\section{Figura 3 - Símbolos da Festa do Çairé}

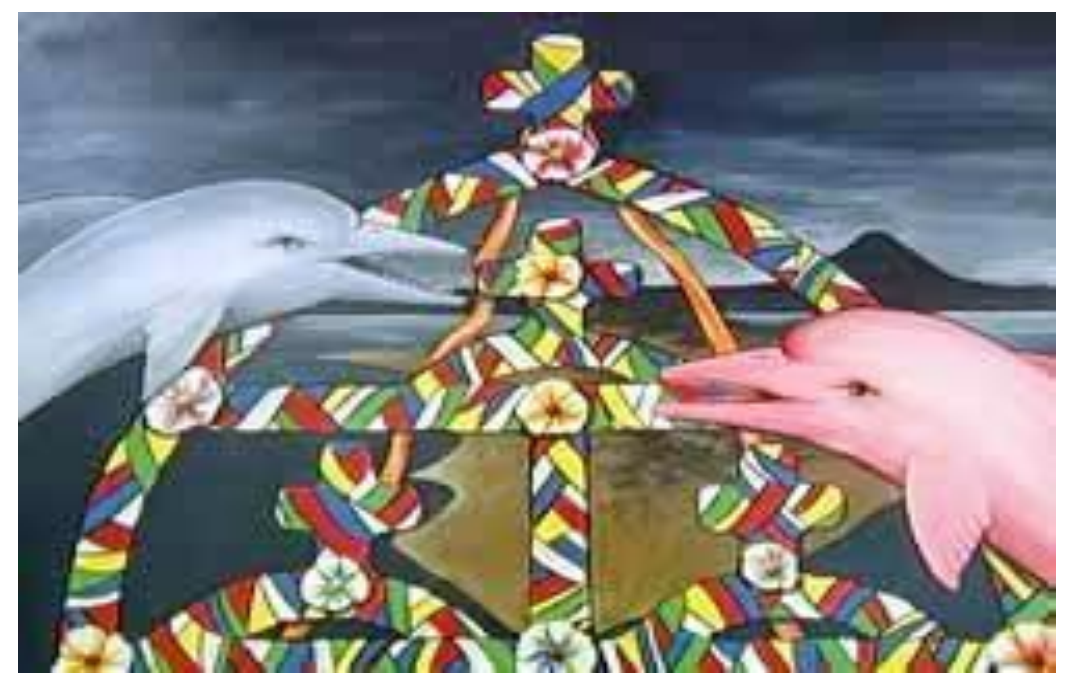

Fonte: Cartaz do Çairé $2010 \quad$ Disponível

em:

<http://encantosdesantarem.blogspot.com.br/2010/07/saire-2010.html>

Mesmo tendo incorporado os elementos religiosos jesuíticos, a realização da Festa do Çairé foi proibida durante 30 anos pela Igreja Católica. Segundo Figueira (2011), em 1973, por iniciativa dos próprios comunitários e baseando-se em lembranças passadas, a Festa do Çairé foi reeditada nos seus antigos moldes e, em 1996, por sugestão do Governo Municipal, o ritual do Çairé foi reinventado com a inserção da disputa entre as agremiações folclóricas dos botos Cor-de-Rosa e Tucuxi, inspiração do Festival dos Bumbás de Parintins. Para Figueira (2011, p. 5), “[...] pode-se conjeturar que o Sairé ressurgiu num processo de rememoração coletiva. Este não foi revivido como antes, pois as lembranças foram construídas com representações do tempo presente", justificando esta fala, a autora lança mão de Bossi (1994) para afirmar que "[...] por mais nítida que nos pareça a lembrança de um fato antigo, ela não é a mesma imagem que experimentamos na infância. Essas imagens se alteram porque jamais seremos a mesma pessoa de ontem” (apud FIGUEIRA, 2011, p.5). Contudo, “[...] os elementos da 'tradição' podem ser reorganizados para articular as diferentes práticas e posições e adquirir um novo significado e relevância" (HALL, 2003, p. 260).

Da "tradição" mantiveram-se os personagens, as ladainhas, as cantigas, as procissões, a louvação e o puxirum, que sugeridos nos discursos dos comunitários carreia as marcas e expressões coletivas de uma cultura singular, como bem sugere a fala da comunitária Luzia dos Santos Lobato:

A gente não tinha o que apresentar no salão para chamara atenção do povo, além da
reza. Aí, fomos buscar nossas danças que a gente dançava nas colônias, nas festas
antigas e nos puxirum. Então, a gente dançava e começava pelo curimbó, que o nosso
não é carimbó, nós dançávamos o lundum, desfeiteira, o marambiré, dançava
marabaixo. Por sinal, a gente criou a valsa da ponta do lenço. Existia o Espanta Cão,
eles eram um conjunto e ficam responsáveis por esta dança e a gente se apresentava
muito bonito ( FIGUEIRA, 2011, p. 6).

Quando analisado a partir do conceito de cultura enquanto "teia de relações" (GEERTZ, 1989, p. 4), o Çairé, enquanto evento histórico, traz consigo um significado peculiar, que só pode ser entendido no seu contexto e a partir do seu contexto, pois o Ser Humano tem 
necessidade de construir significados para orientar sua convivência em sociedade, mas estes só podem ser compreendidos no próprio ambiente em que foram construídos. Enquanto fenômenos históricos é preciso interpretá-los em sua singularidade e unicidade (FIGUEIRA, 2011).

Ainda porque o Çairé reinventado é a reinvenção da própria tradição “[...] pensada como um mecanismo de seleção, e mesmo de invenção, projetada em direção ao passado para legitimar o presente" (BLANCHE, 1989 apud CANCLINI, 2006, p. 219), é a atribuição de um novo sentido aos velhos acontecimentos, pois "[...] as tradições podem ser fonte simultânea de prosperidade econômica e afirmação simbólica. Nem a modernização exige abolir as tradições, nem o destino fatal dos grupos tradicionais é ficar de fora da modernidade" (CANCLINI, 2006, p. 239). E ainda, "a compreensão do cotidiano amazônico passa, necessariamente, pela leitura crítica do passado, tecida na relação de seus habitantes com o modo de produção em processo" (NOGUEIRA, 2008, p. 33).

Segundo Nogueira (2008), o Çairé, enquanto folguedo popular, diferencia-se dos demais por estar, diretamente, vinculado ao processo e origem da colonização da Amazônia pelos portugueses e também porque, influenciado pela profissionalização e espetacularização do Festival dos Bois-Bumbás de Parintins (AM), da Ciranda de Manacapuru (AM), cresceu em participação e intenção, e influenciou, ainda, na ampliação do Festribal de Juruti, onde as Tribos Munduruku e Muirapinima, inspiradas na competição e rivalidade dos Botos Tucuxi e Cor-deRosa, travam verdadeiras batalhas, assim "[...] O produto cultural é, agora, emanação de outra identidade, a do capital que se apropriou dos espírito da festividade popular, comprou o trânsito entre o material e o simbólico, descobriu o segredo da reprodução e lança-se à competição" (NOGUEIRA, 2008, p. 18). Esses folguedos, segundo Nogueira (2008, p. 119), "obtiveram, com as mudanças, relativa inserção na programação cultural dos seus Estados, influência política e econômica como valor agregado da indústria de turismo e dos meios de comunicação", despertando os interesses e olhares de um quantitativo expressivo de espectadores, telespectadores e patrocinadores.

Para Nogueira (2008), em relação ao mercado, as festas populares podem ser compreendidas em três momentos distintos: distanciadas, em processo de integração e integradas. Nas festas distanciadas "a ação e o sentido estão voltados à produção e ao cotidiano" (NOGUEIRA, 2008, p. 37), na satisfação e realização da coletividade, dos comunitários; nas festas em processo de integração encontram-se "aquelas que se articulam com o mercado" (NOGUEIRA, op. cit.), mas ainda assim preservam as dimensões controláveis do ethos comunitário e; em terceiros estão aquelas chamadas integradas, que exprimem um sentimento de localidade, "mas que se realizam sob a dimensão desterritorializada e dominada por leis mercadológicas - ou por aparelhos culturais [...] sem o controle social e sem o controle econômico dos grupos que as produzem" (NOGUEIRA, 2008, p. 37). Neste trânsito, percebemos que dependendo dos movimentos que distanciam ou integram as festas da floresta ao mercado capitalista, estas poderão ser mais ou menos alienantes, ao ponto que as coletividades que as produzem tenham as condições necessárias para se contraporem à hegemonia globalizante do capital, através das mesmas contradições surgidas nas relações com os determinantes do próprio capitalismo, espetacularizado para a mídia nas exibições dos festivais, nas suas tradições culturais encasuladas nos tecidos chineses holográficos, nas plumas, penas de faisão e paetês importados - nas festas pra gringo ver - enquanto seus reais idealizadores, no brilho dos holofotes, veem dissipadas a simplicidade e o encantamento da sua arte. 
O mesmo pode-se dizer do pensamento de Walter Benjamin sobre a arte na era da reprodutibilidade técnica. Continua atual a sua preocupação com a possibilidade da tecnificação da arte de afastar os indivíduos e as suas coletividades dos seus afazeres e fazeres artísticos. Afinal, na produção simbólica e material está cunhada a organização e a percepção dos grupos sociais sobre a sua existência. (NOGUEIRA, 2008, p. 24-25).

Os eventos mencionados, anteriormente, fazem parte dos densos estudos de Nogueira (2008) a respeito de como as festas populares amazônicas do Festival dos BoiBumbás, Ciranda de Manacapuru e o Çairé de Alter-do-Chão, e a estas acrescentamos o já evidente Festribal de Juruti, se relacionam com o mercado capitalista; seja em forma de distanciamentos, processo de integração ou integração, pois:

São eventos que resultam de um longo processo de confronto entre o modo de produção capitalista e a produção simbólica local, territorializada e marcada socialmente pelo controle de grupos tradicionais. [...] No mercado, as festas são feitas para ser consumidas como entretenimento, posição social ou identidade cultural (NOGUEIRA, 2008, p. 38).

Observemos que nenhuma das festas citadas seriam as mesmas sem os lugares que as significam. A Festa do Çairé, por exemplo, jamais seria a mesma se descolada do bucolismo fetichizado da Vila de Alter-do-Chão e do marketing que se constrói a partir do habitat das tribos dos Tupaiús, Tapajó e Boraris. Assim, a força étnica, também é fetichizada pelo mercado dos bens simbólicos, adaptados na linguagem da mídia e de seus mecanismos derivados, modificando, desta forma, "todos os aspectos das festas, suas tradições, seus sujeitos e atores. Novas funções, novas linguagens e novos desafios emergem dos ambientes e contextos das festas, a indústria cultural cria e recria a espacialização própria” (NOGUEIRA, 2008, p.16). Isto acontece porque "As localidades e os grupos sociais são referências de fundamental importância para os interesses do mercado, [...]. denomina-se a festa e o lugar. Os agentes de turismo criam e alimentam a expectativa de existência de um produto cultural característico de um lugar, de um determinado grupo social" (op. cit. p. 39).

De maneira geral, não nos furtamos em acreditar que a indústria cultural, a despeito das promessas de padronização dos bens culturais, não mostrou eficácia nenhuma na resolução dos conflitos sociais. "O conceito de indústria cultural, com toda a carga ideológica que lhe foi atribuída nos primórdios do cinema e do rádio, ainda tem força de análise nos tempos atuais, do triunfo da televisão e da internet" (NOGUEIRA, 2008, p. 24-25). Em seu estudo, Nogueira (op.cit.), também percebeu que o processo de integração da Festa do Çairé ao mercado capitalista e sua maior visibilidade midiática, auxiliado pela Amazônia enquanto marca da linguagem mercadológica, pouco favoreceu na melhoria da qualidade de vida da população de Alter-do-Chão, pois, imediatamente, esta maior exposição midiática foi revertida integralmente em especulação imobiliária e econômica, havendo então um esvaziamento na participação dos nativos da vila, principalmente, na parte religiosa, conforme ilustra o depoimento de um dos comunitários: "[...] o festival dos botos foi muito grande e diminuiu a participação do povo na parte religiosa do Sairé, na parte tradicional [...]” (FIGUEIRA, 2011, p. 10).

Nestes eventos, em particular, o grau de complexidade é aumentado quando os fenômenos são dissecados segundo as abordagens sobre o mercado de bens simbólicos. Evidentemente que não há como delimitar características específicas que possam determinar o envolvimento ou não de uma festa pelo mercado, porém alguns fatores evidentes podem sinalizar esta possibilidade. Nogueira (2008, p.39) indica que em seus estudos as festas 
comumente apresentaram alguns indícios: "tem identidade jurídica, ampla divulgação nas mídias, são negociadas como produtos turísticos, mobilizam simpatizantes por meio da disputa polarizada e são produzidas e realizadas de acordo com técnicas correntes no mercado”. Pois, Marilene Freitas prefaciando Nogueira (2008, p. 14-15), afirma que:

Os folguedos das brincadeiras, celebrações e manifestações lúdicas são factuais e constituintes de uma racionalidade que emerge da presença que a importância das festas adquire. Produtores e cultores das festas tradicionais estudadas ofertam entre a satisfação de brincar e a ambição de vender. [...] O que era isolado e representativo de uma identidade coletiva molda-se a outras representações mais amplas do imaginário nacional e transcultural. Não há distâncias e nem limites para incrementar a ação do mercado na oferta do encantamento. O material que ilustra as condições culturais de distanciamento e de integração das festas ao mercado são os pontos opostos entre as tradições de suas sociedades, as suas formas de estabilidade, e as relações de mercado e seus níveis de profissionalização. [...] As festas organizam-se como negócio turístico, como espetacularização movida pela necessidade de agradar, determinada pela linguagem midiática que pontua produtores, vendedores e consumidores de suas atrações.

Similar ao que já acontece no carnaval do Rio de Janeiro e ao Festival dos Bumbás de Parintins, como festa amazônica de maior visibilidade, no Çairé, também, são desenvolvidas estratégias que prendem e distanciam os grupos sociais de suas obras e do mercado que as engendra. Como "[...] É o fenômeno de massa que comanda o nível de distanciamento e/ou de integração entre aqueles que as inventaram (as festas) como criação coletiva, e os que se apropriam e vendem os processos e produtos culturais alheios" (NOGUEIRA, 2008, p.41), além de que atuam como determinantes, nos ritmos e intensidades das reproduções artísticas, tornando seus reais atores, como coadjuvantes dos seus próprios espetáculos.

Estes que viram espetáculos para as mídias são resultados imediatos da expropriação, apropriação e fetichização das festas comunitárias para o jogo de interesses do capitalismo. Pois, tanto o Çairé, quanto as demais festas amazônicas exigem, segundo Nogueira (2008), um "artesanato intelectual" muito grande e este se constitui no maior valor que poderia ser agregado aos produtos e eventos culturais amazônicos. O "artesanato intelectual" a que se refere Nogueira (2008) é fruto da dedicação dos comunitários na produção de espetáculos para as lentes externas dos jornais, revistas, televisão e, especialmente, da internet. Contudo, esta visibilidade midiática cobra dos grupos folclóricos a padronização técnica necessária para as projeções ao vivo, nisto incorpora-se, inclusive, as modificações arquitetônicas para as transmissões, onde se alteram, as arquibancadas, os camarotes, os palcos, a iluminação, a carga energética e, principalmente, os modelos dos "terreiros"2 ou melhor das arenas, onde, contrariamente ao modelo do sambódromo do Rio de Janeiro em que o espetáculo passa, no Sairódromo, no Cirandódromo e no Tribódromo, assim como no Bumbódromo, o espetáculo inicia e não passa, cresce e permanece até o fim. "São lugares edificados pelo poder público, para abrigar espetáculos e, portanto apropriados como espaço de e/ou para o mercado" (NOGUEIRA, 2008, p. 41).

A mercadoria é misteriosa simplesmente por encobrir as características sociais do próprio trabalho dos homens, apresentando-as como características materiais e propriedades sociais inerentes aos produtos do trabalho; por ocultar, portanto a relação entre trabalhos individuais dos produtores e o trabalho total, ao refleti-la como relação

\footnotetext{
${ }^{2}$ Espaços comunitários onde eram, tradicionalmente, realizadas as festas.
} 
social existente, à margem deles, entre os produtos do seu próprio trabalho. Através dessa dissimulação, os produtos do trabalho se tornam mercadorias, coisas sociais, como propriedades perceptíveis e imperceptíveis aos sentidos (...) Chamo isso de fetichismo, que está sempre grudado aos produtos do trabalho, quando são gerados como mercadoria (MARX 1996 apud NOGUEIRA, 2008, p. 45-46).

"Materializado na força do Estado e nas relações de determinação do mercado, o produto cultural adquire outra essência, tanto quanto os produtos separam-se da força social que os produziu e produzirão como réplicas de boa aceitação ao consumo do lazer" (NOGUEIRA, 2008, p. 19). Desta forma, tanto Çairé, quanto as demais festas populares, eventos históricos da Amazônia, que no passado só viajavam e, dos quais só se tinham notícias, através das ondas (banzeiros) dos rios que conduziam as naus, catraias, gaiolas, batelões, regatões; agora viajam nas ondas de rádio e nos cabos de fibra ótica.

Se antes a Amazônia se via, mas não via o mundo, devido os seus apagões estruturais, hoje a Amazônia consegue ver muito do mundo, mas a opacidade do capitalismo não nos deixa enxergar nossas próprias raízes, nossas diversidades culturais e sociais. Porém, a despeito de nossas expectativas mais promissoras:

\begin{abstract}
Uma tomada de consciência positiva, realista e de esperança voltada para a melhoria de vida e para o desenvolvimento socioeconômico regional constitui o primeiro passo nessa direção. De outro lado, não se pode esquecer o fato de que nas sociedades carentes o cotidiano assume tal proporção que o engenho e a arte se desligam do amanhã e se concentram apenas no clamor e nas soluções de emergência do dia-a-dia (BENCHIMOL, 2009, p. 497).
\end{abstract}

Se as mídias fazem da Amazônia, e de seu patrimônio cultural, mercadoria fetichizada do capitalismo para a indústria cultural, se as brincadeiras são apartadas dos seus brincantes, os terreiros acanhados são escarificados pelas máquinas da construção das arenas, a tradição é afastada da cultura, a cultura regional é encandeada pelos flashs capitalistas do mercado, as identidades amazônicas são diluídas na fumaça da globalização e o lazer é esvaziado pela obrigatoriedade em agradar, em não sair do script; se as :

pressões e constrangimentos ecológicos e ambientais que, partindo de dentro ou fora do país, podem frear ou inviabilizar o desenvolvimento, transformando a Amazônia num santuário ecológico para desfrute da vida selvagem, para vender para o ecoturismo exótico e de aventura [...]. Ao lado do enorme potencial amazônico de recursos naturais, florestais, minerais, energéticos e biotecnológicos é preciso relembrar que esses recursos per si não garantem a certeza de um desenvolvimento sustentável. È preciso criar condições de infraestrutura científica, tecnológica e, sobretudo, de recursos humanos qualificados para esse nível de bem-estar futuro venha a ocorrer. $\mathrm{O}$ cenário do futuro não contempla nível de emprego e renda para analfabetos formais e funcionais, iletrados, inumerados e não-informatizados. O bom saber e o bem fazer serão instrumentos indispensáveis para a materialização desse futuro. (BENCHIMOL, 2009, p. 498)

Então, mais do que nunca "é bom alertar, de vez em quando, que não basta empurrar a porta, sair e começar a caminhar. É preciso, também, abrir a janela que, sem romper nosso passado cultural, a nossa identidade amazônica e brasileira, devemos estar de braços e mentes abertos para receber o futuro" (BENCHIMOL, 2009, p. 498-499). Receber o futuro, desta forma, não significa esquecer o passado, mas antes de tudo, saber conviver com as mudanças sem abdicar da simplicidade da cultura tecida em tradições seculares. Assim se fez o Çairé pela disputa dos botos - Cultura Amazônica reinventada pelo Mercado para a Mídia - festa pra gringo ver, onde os festejos religiosos dividem espaço com a Indústria Cultural do profano, onde a 
tradição vira souvenir, mercadoria da mídia para o turismo e onde os povos amazônidas, com a promessa de visibilidade internacional proporcionada pela mídia para o fomento do turismo, se deixam usar pelo capitalismo mais cruel como mão-obra barata na produção dos eventos culturais amazônicos.

\section{Referências}

AULETE, Caldas. Novíssimo dicionário contemporâneo da língua portuguesa. Rio de Janeiro: Lexikon, 2011.

BENCHIMOL, Samuel. Amazônia - Formação Social e Cultural. $3^{\text {a }}$ ed. Manaus: Editora Valer, 2009.

BOSI, Ecléa. Memória e sociedade: lembranças de velhos. $3^{\text {a }}$ ed. São Paulo: Companhia das Letras, 1994.

CANCLINI, Nestor Garcia. Culturas Híbridas. 4ªed. São Paulo: EDUSP, 2006.

CARTAZ DO ÇAIRÉ - $\quad 2010.2010$ Disponível em: http://encantosdesantarem.blogspot.com.br/2010/07/saire-2010.html. Acesso em 23 de Agosto de 2015.

IDH. Programa Nacional das Nações Unidas para o Desenvolvimento. Disponível em: http://www.pnud.org.br/ Acesso em: 08 de janeiro de 2015.

FIGUEIRA, Cláudia Laurido. Tradição, memória e poder: Sairé, manifestação cultural reinventada - 1974 a 1996. In: Anais do XXVI Simpósio Nacional de História - ANPUH. São Paulo: Julho de 2011.

GEERTZ, Clifford. A interpretação das culturas. Rio de Janeiro: LTC, 1989.

GUIA QUATRO RODAS. Disponível em: http://viajeaqui.abril.com.br/cidades/br-pa-alter-dochao/fotos . Acesso em: 23 de agosto de 2014.

HAGE, Salomão Mufarrej; BARROS, Oscar Ferreira. Currículo e educação do campo na Amazônia: Referências para o debate sobre a multisseriação na escola do campo. In: ESPAÇO DO CURRÍCULO, v.3, n.1, pp.348-362, Março de 2010 a Setembro de 2010. Disponível em: < http://periodicos.ufpb.br/ojs2/index.php/rec >. Acesso em: 05 de janeiro de 2015

HALL, Stuart. Da diáspora: identidade e mediações culturais. Belo Horizonte: UFMG, 2003.

IBGE - Instituto Brasileiro de Pesquisa e Estatística. Mapa da Amazônia Legal. Brasil: 2010. Disponível em: <www.ibge.gov.br>. Acesso em 23 de setembro de 2014.

IBGE - Instituto Brasileiro de Geografia e Estatística. Brasil termina o século com mudanças sociais. <www.ibge.gov.br>. Acesso em 23 de setembro de 2014.

KENSKI, Vani Moreira. Tecnologias e ensino presencial e a distância. Campinas: SP: Papirus, 2003.

LÉVY, P. Cibercultura. São Paulo: Editora 34, 1999. 
NERI, M. C. Mapa da inclusão digital. Rio de Janeiro: FGV/CPS, 2013.

NOGUEIRA, Wilson. Festas Amazônicas - boi-bumbá, ciranda e sairé. Manaus: Valer, 2008.

PINTO, Lúcio Flávio. 30 anos de grandes projetos na Amazônia. In: Jornal Pessoal \& Gramsci e o Brasil. Disponível em: <http://www.acessa.com/gramsci>. Acesso em : 05 de janeiro de 2015.

RICOEUR, Paul. A memória, a história, o esquecimento. Campinas: Editora Unicamp, 2007.

VEYNE, Paul. Como se escreve a historia: Foucault revoluciona a historia. 4. ed. Brasilia: Editora Universidade de Brasília, 1998. 285 p.

ZACHARIAS, Suraia; COSTA, Diva de Souza. A questão pedagógica na relação educação e trabalho. EX-CATACUMBIS. Ano I. Vol.I. SSA, Outubro de 1996, Número Zero. 


\section{Rádio e a saúde dos moradores às margens rio Purus, em Lábrea/AM}

Fábio Teixeira Lima (UNIR/IFAM)

José Lucas Pedreira Bueno (UNIR)

\section{Considerações iniciais}

Dentre os vários problemas enfrentados pela população do município de Lábrea/AM, a saúde pública é talvez a mais preocupante. Isso porque envolvem vários fatores nas áreas econômicas, sociais e culturais.

No caso do aspecto econômico, a falta de dinheiro, a população, que é na sua maioria de baixa renda, a prevenção à saúde fica comprometida, pelo fato de que sem dinheiro, as condições de moradia e saúde se tornam cada vez mais dificultosas, pois a maioria das moradias, não possui saneamento favorável à prevenção da hepatite $\mathrm{B}$.

Ainda no aspecto econômico, há problema na qualidade da água que a população ingere; trata-se de água in natura, sem o devido tratamento. E em geral as fossas sépticas comprometem a qualidade da água, devido ao fato de o lençol freático ser muito próximo da superfície.

Com relação ao aspecto social, a hepatite B se dissemina pela falta do processo educacional, que deixa mais vulnerável os modos de transmissão dessa doença. A população às vezes até sabe que se trata de uma doença grave, mesmo recebendo as informações não faz uso dos meios que já existem para evita-la.

Durante a realização da pesquisa, que cunhou na elaboração deste artigo cientifico, tendo como objeto de pesquisa a importância do rádio como comunicação de massa, no combate à proliferação da hepatite $\mathrm{B}$, entre o período de 1985 a 1995, pode perceber que a desvalorização do ser humano continua e que a falta de comunicação, permanece sendo o grande obstáculo, para o desenvolvimento cultural, social, educacional e informação, para toda a região do rio Purus e seus afluentes.

O interesse pelo tema foi se fortalecendo por ter vivenciado, no final da década de 80, a presença ilustre do ex-presidente José Sarney, na cidade de Lábrea/AM, para o lançamento da campanha de vacinação anti-hepatite $B$, o que na época houve uma grande presença populacional na Praça da Matriz, para ver o presidente, e o rádio com seus programas diários anunciavam a vinda do Presidente da República do Brasil aos lugares mais distantes do município. E a Voz do Brasil ${ }^{1}$, que divulgava a agenda semanal do presidente, a emissora de

\footnotetext{
${ }^{1}$ A Voz do Brasil está no ar há mais de 70 anos. O objetivo é levar informação aos cidadãos dos mais distantes pontos do país. 
televisão $\mathrm{SBT}^{2}$, também apresentava aos domingos a semana do Presidente da República do Brasil, e a agenda de visitas para próxima semana, durante as décadas de 1980 e 1990, mas como muitas comunidades ribeirinhas ainda não tinham televisão, o rádio foi o grande responsável pela presença maciça da população e, ainda havia outros programas diários, bastantes ouvidos, que levavam as informações necessárias, aos lugares mais distantes da região norte os programas da Tia Heleninha ${ }^{3}$ (Encontro com Tia Heleninha), Edelson Moura e Márcia Ferreira $^{4}$ (Programa da Radio Nacional), Rádio Difusora ${ }^{5}$ (Programa Josué Filho) e Rádio Rio $\operatorname{Mar}^{6}$ (Programa de Aviso).

Os programas de rádio também contribuíam com as campanhas de vacinação, divulgando as datas tipos das vacinas que serão aplicadas, como também sua importância, para a prevenção de doenças.

Mas, apesar dos alertas com relação às doenças, as notícias acabavam criando um problema social, pelo o medo de receber as doses de vacina os jovens se embrenhavam na floresta, para não serem vacinados, tendo em vista as reações alérgicas causadas pela vacina anti-hepatite B.

Um fato interessante no desafio para combater a proliferação da hepatite $\mathrm{B}$, é que apesar do lançamento da vacina ter ocorrido a mais de 30 anos, a população continuar sofrendo com a doença, autos índices de infectados e óbitos, percebemos durante as pesquisas que houve uma grande redução de pacientes infectados, mas pelo tempo que foi lançada à vacina, era para ser bem menor, mas de acordo com o agente comunitário Antônio David:

As pessoas com mais de 40 anos, que convivem com o vírus da hepatite $\mathrm{B}$, existem muitos casos que a pessoa pegou de sua mãe que tinha os vírus, mas a falta de conhecimento e exames periódicos nas margens do rio Purus não detectaram o problema e como a vacina só foi lançada em 1989, essas pessoas ao nascerem, já contraiam o vírus (LIMA, 2012, entrevista).

Mas destacamos o rádio como um meio de fazer chegar às noticias, nas comunidades mais distantes e carentes da Amazônia, fortalecendo assim a sua grande importância social, por meio de seus locutores, que além de se tornarem ídolos de seus ouvintes, também contribuem com esse papel social de informar e prevenir.

O locutor da rádio não necessita mais falar afetado; pois não seria se quer possível que o seu sotaque não se distinguisse pelo caráter de entonação do grupo de ouvintes que lhe foi assegurado. Mas, em troca, o modo de se exprimir e de gesticular dos ouvintes e dos espectadores, chegando até as nuanças que nenhum método experimental está em condições de captar (ADORNO, 2002, p. 43).

\footnotetext{
${ }^{2}$ Sistema Brasileiro de Telecomunicações, de propriedade de empresário Silvio Santos.

${ }^{3}$ A inesquecível Tia Heleninha fez história na Nacional de Brasília. Para chegar mais perto do público infantil.

${ }^{4}$ Marcia Ferreira e Edelson Moura, que durante 18 anos tomaram conta da audiência das regiões: Norte, Nordeste e Centro Oeste, através da programação da Rádio Nacional de Brasília, do sistema Radiobrás.

${ }^{5}$ Fundada no dia 24/11/1948, a voz de Josué Cláudio de Souza, que as ondas do rádio tornaram inconfundível para os amazonenses, ganhou um tom especial de emoção, anunciando: "Está no ar a Rádio Difusora do Amazonas, estação ZYS-8, a mais poderosa da planície e a mais querida de Manaus, operando na frequência de 4.805 kilociclos, ondas interme diárias de 62,40 metros".

${ }^{6}$ A Rádio Rio Mar foi inaugurada no dia 15 de novembro de 1954, às 17h, sob as bênçãos do Pe. Agostinho Caballero Martin. Desde o primeiro dia em que foi ao ar, a emissora vem fazendo história, deixando a sua marca na radiodifusão amazonense e brasileira, como a primeira estação de rádio do Amazonas a operar em Ondas Médias e a única, até hoje, a transmitir em Ondas Curtas em toda a região Norte, possibilitando ao caboclo do interior ouvir a emissora em qualquer lugar.
} 
Com essa introdução o presente trabalho busca elucidar a influência do rádio, para tentar amenizar a situação precária das populações ribeirinhas do Rio Purus, que tanto sofrem com as secas e cheias do Rio, alertando os moradores para os perigos de proliferação causados pela a hepatite $\mathrm{B}$.

\section{A saúde pública de Lábrea/AM e o rádio como meio de informação e prevenção}

De acordo com Silva (2010, p.144), “o município de Lábrea fica situado à margem direita do Rio Purus, tendo como afluentes os Rios: Paciá, Ituxí, Sepatini, Acimã, Tumiã, Seruini, Mamoriazinho e Mamoriá".

Segundo Silva (2012, p. 28), "a economia é voltada ao extrativista, com: a extração da borracha, a pesca, a castanha, a farinha, a madeira e outros produtos naturais". Além da agricultura de subsistência, atividade comum das comunidades ribeirinhas.

As comunidades que ficam localizadas, no Rio Purus e seus afluentes, muitas vezes ficam desassistidos pelo poder público, devido às dificuldades de acesso aos moradores e as precariedades de comunicação na região, tendo o rádio como uma das formas mais comuns de contato com essas comunidades, que vive em sua maioria nas margens ribeirinhas do município.

Mesmo durante os períodos de campanha de vacinação, o principal meio de avisar as comunidades é através do rádio, para alertar sobre a vacinação e prevenção da hepatite $\mathrm{B}$ e outras doenças.

Pois os programas dos rádios levam as informações necessárias, para que os moradores dos lugares mais longínquos, possam se prevenir das contaminações. Apesar de receberem as informações básicas, essas populações, não têm a cultura do uso dos mecanismos, que existem para evitar a transmissão de certas doenças contagiosas.

Assim, a falta de água tratada, promiscuidade sexual e falta de higiene no que se refere ao preparo dos alimentos, torna a hepatite $\mathrm{B}$, uma doença muito comum na população local, não importando a faixa etária.

Segundo Hoggart (1973, p. 121) "A promiscuidade sexual é fruto de uma antiga tradição, mas as relações sexuais processam-se às escondidas e em condições desfavoráveis". Isso significa que mesmo durante as campanhas de prevenção a hepatite $B$, doenças continuavam se proliferando por meio das relações sexuais, devido à falta de cuidados e, também, muitas vezes, pela curiosidade de descobrir o sexo muito cedo, sem ter conhecimento dos riscos que poderão trazer a saúde.

Com o rádio avisando dos cuidados e formas de transmissão das doenças pelo sexo, percebemos que as campanhas de prevenção à doença sexualmente transmissíveis ainda não são aceitas para a educação sexual dentro das comunidades ribeirinhas, pois há o desconforto das pessoas falarem abertamente de sexo, principalmente relatar as angustias e anseios. As moças e rapazes não se sentem à vontade para relatar o que afligem relativo aos cuidados durante a relação sexual.

$\mathrm{Na}$ cultura ribeirinha, alguns vícios obtidos dos mais antigos são mantidos pelas novas gerações, como: não lavar as mãos antes das refeições, tomar banho no rio, beber água do rio, usar os mesmos talheres e não ir ao médico regularmente.

Sabemos que o problema de comunicação e meios utilizados nas propagandas das campanhas de vacinação, para a região e um grande desafio, em função da ausência desta comunicação globalizada, que não consegue atingir toda a população brasileira e principalmente 
da Amazônia. Nesse sentido como relatam os escritores Allan. S. B. Rodrigues e Grace. S. Costa, quando discutiram sustentabilidade, preservação e conservação do meio ambiente, durante o Rio-92, fazem um alerta para a carência de:

[...] estratégias comunicacionais elaboradas para atingir os receptores através dos veículos de comunicação de massa (TV's, Rádios, Internet e outros) chegaram de forma deficitária nos chamados "beiradões", onde residem pessoas com baixa escolaridade e que tiram o sustento da caça, da pesca, dos roçados e da atividade extrativa (RODRIGUES; COSTA, 2000, p. 37).

Quanto aos aspectos de comunicação, a região do Purus sofre bastante pela falta de informação importante para seu desenvolvimento social e o rádio acaba sendo um meio de comunicação mais utilizado e ouvido pelas populações ribeirinhas. O rádio tem tanta importância que na época áurea da borracha os seringueiros tinham o rádio como meio de diminuir a saudade da família e ouvir as notícias do mundo.

Neste contexto social o rádio passa a fazer parte da necessidade do cotidiano familiar, pois é a única forma de saber o que acontece no mundo exterior, sendo que a maioria da população fica isolada nas comunidades rurais ou ribeirinhas e ainda prevalece a cultura de ouvirem programas de rádio como forma de amenizar a falta de informações, para essas populações.

Para Adorno (2002, p. 37), relatando sobre a importância do rádio como cultura de massa, afirma que: "Em toda parte, o rádio, fruto tardio e mais avançado da cultura de massa [...]", ou seja, ainda são uns dos meios de comunicação muito utilizados pela população.

A valorização do rádio como mecanismo sociocultural está presente nos discursos dos médicos sanitaristas que trabalhavam na prevenção de doenças na Amazônia, mas o problema é muito maior, pois envolve uma presença significativa do poder público nas comunidades, principalmente com relação às necessidades básicas do cotidiano de infraestruturas.

De acordo com o médico especialista em saúde pública (SCLIAR, 2007, p. 30); “o conceito de saúde reflete a conjuntura social, econômica, política e cultural". Para a realidade do município de Lábrea se torna muito comum, porque a maioria da população depende diretamente dos programas sociais oferecidos pelos governos, além, é claro, da falta de médicos, hospitais de qualidade e equipamentos adequados para certos exames.

Durante as décadas de 80 e 90 era comum o programa da Tia Heleninha, Edelson Moura e Marcia Ferreira, a Rádio Difusora e Radio Rio Mar, anunciarem a visita da Corveta ${ }^{7}$ nos lugares onde havia carência de saúde, trazendo assistência básica de saúde como: consultas médicas, extração de dentes e aplicação de vacinas.

Este trabalho também apresenta outro agravo da hepatite $\mathrm{B}$, e sua forma de classificação, analisada pela pesquisadora Gilberta Bensabath, médica sanitarista, como febre negra de Lábrea/AM, por ter um tempo determinado, para que a pessoa chegasse a óbito e a valorização do rádio, para divulgar os riscos de vida e os meios de prevenção, para que doenças facilmente transmissíveis não matassem mais pessoas, como a febre negra, que matava com ataques fulminantes.

\footnotetext{
${ }^{7}$ Tipo de navio, originalmente uma embarcação de guerra, à vela, de dimensões inferiores às da fragata, surgida nos finais do século XVIII, e que na Amazônia ficou conhecida como meio de levar tratamento de saúde as comunidades mais distantes.
} 
A febre de Lábrea, também conhecida como hepatite de Lábrea, é uma hepatite fulminante que ocorre principalmente na margem direita do Rio Amazonas, na Amazônia Ocidental (Estados do Acre, Amazonas e Rondônia). Esta denominação tem valor histórico porque os primeiros casos que o IEC/SVS tomou conhecimento ocorreram no município de Lábrea. A doença ocorre sob a forma de surtos familiares, com maior incidência em crianças do sexo masculino. Há um período inicial de febre, vômito falta de apetite e logo surgem sintomas neurológicos como, agitação, delírio, convulsões e coma hemorrágicos. Nos estudos efetuados, a morte ocorre, em média, seis dias após o início dos sintomas. Na grande maioria dos casos o VHB e o vírus delta estão presentes nos indivíduos acometidos. A infecção pelo vírus delta pode ser em portador do VHB ou os dois vírus o VHB e o VHD infectarem uma pessoa ainda não infectada. O VHD só pode se multiplicar na presença do VHB. Portanto, vacinando contra a VHB, uma pessoa fica livre do contágio do vírus delta (O Liberal, 2005, p. 3).

As águas do Rio Purus são denominadas de cor branca mais deveria ser chamado de rio de água amarelada, em virtude da grande quantidade de terra que caí dos barrancos e os troncos de madeira, que desce constantemente pelo rio. Esse fenômeno ocorre durante as duas estações do ano (verão e inverno), dificultando o acesso às comunidades ribeirinhas, pois a cor da água no inverno torna o rio difícil de navegar, porque fica muito cheio, facilitando a transmissão de doenças e durante o verão ocorrem as secas, que também dificulta o acesso à navegação.

Neste contexto as comunidades ficam desassistidas pelo poder público e os avisos dos rádios, são o único meio das informações chegarem a essas comunidades, quanto às dificuldades de acesso a navegação no Rio Purus, foi relatada por Euclides da Cunha:

\begin{abstract}
Está, evidentemente, sobre a ruinaria de uma sublevação quase extinta, cujo sinclinal ele pôde reconstruir, prolongando as linhas dos estratos que afloram nos sulcos onde se encaixam aqueles últimos tributários, denunciando todos na tranquilidade relativa, quase remansados nos intervalos de suas corredeiras (restos de velhíssimas catadupas destruídas), a derradeira fase de uma luta em que o Purus, para alongar a sua seção de estabilidade, teve que derruir montanhas. Pelo menos a atividade erosiva e o volume de materiais arrebatados de todos aqueles pendores, foram incalculáveis, para que as linhas de drenagem se abatessem até ao substractum rochoso e declinassem, como vimos, aos graus apropriados aos cursos navegáveis. (CUNHA, 2006 p. 12).
\end{abstract}

Essa mesma água amarelada do Rio Purus e a que abastece as casas dos moradores, para todas as necessidades básicas, sem que haja cuidados necessários, que possam purificar a água antes de ser consumida.

A falta de água potável, para as comunidades ribeirinhas favorecem a proliferação de doenças contagiosas, como aconteceu, no início da década de 1990, com uma grande epidemia de cólera. A problemática é analisar como foram feitas as primeiras formas de prevenção, para que houvesse meios de controle e cuidados específicos com doentes, para que eles não contaminassem outras pessoas, tendo em vista as formas de prevenção para evitar as contaminações em massa, desde a prevenção na forma de aplicação da vacina, os mecanismos de esterilização ainda nas zonas ribeirinhas da Amazônia não eram seguras, como relata o professor José Carlos Ferraz Fonseca, quando fala de sua experiência durante o período que pesquisava sobre a forma de contaminação da hepatite $\mathrm{B}$, a falta de cuidados com a estilização dos materiais necessários para o exame.

Entre 1979 e 1983, tive a oportunidade de observar várias vezes na zona rural do Estado Amazonas, técnicos de órgãos governamentais, puncionarem com uma só lanceta, inúmeros pacientes febris e com suspeita de malária. Tais técnicos, após a punição retiravam o sangue retido na lanceta através de um chumaço de algodão 
embebido com álcool e posteriormente puncionavam outro paciente. Outros técnicos simplesmente passavam a lanceta no fogo de uma lamparina logo após a punção digital. A referida lamparina servia também para espantar os mosquitos devido a fumaça provocada pelo combustível utilizado, no caso o querosene (FONSECA, 2010, p. 04).

Nesse contexto, é importante ressaltar a importância da melhoria da água, da educação voltada, para a prevenção de doenças e da ajuda à população para perceber que a destruição do meio ambiente local está associada à proliferação da hepatite $\mathrm{B}$ e a contribuição do rádio é levar informações de prevenção à saúde e cuidados com doenças contagiosas e principalmente as datas de vacinação, para que os pudessem proteger seus filhos dos ricos de doenças.

Para a historiadora francesa Moulin (2009, p. 17) "As crianças de hoje não conhecem mais a rubéola, nem a coqueluche ou a caxumba, prevenida por uma vacinação sistemática e obrigatória". A busca de solução para este problema social, econômico e ambiental se constitui um desafio para encontrar uma alternativa para a prevenção, pelo menos que chegue a amenizar o problema de saúde que assola este município.

A televisão tende a uma síntese do rádio e do cinema, retardada enquanto os interessados ainda não tenham negociado um acordo satisfatório, mas cujas possibilidades ilimitadas prometem intensificar a tal ponto o empobrecimento dos materiais estéticos que a identidade apenas ligeiramente mascarada de todos os produtos da indústria cultural já amanhã poderá triunfar abertamente. (ADORNO, 2002, p. 8).

A hepatite só será vencida se o poder público local associado às instituições de saúde e educação, e com maior utilização dos meios de comunicação, tendo em vista que muitas comunidades têm acesso à televisão e o governo precisa utilizar principalmente o horário nobre, para falar dos riscos das doenças. Para Murtinho, seria uma forma do SUS oferecer melhores serviços para população.

Maior pluralidade e diversidade de vozes, maior expressão dos grupos sociais, ampliando o debate público. Por que a TV pública, hoje, não tem expressão? Porque ela é um pássaro estranho no ninho. Desde a década de 1930, a radiodifusão se consolidou como meio comercial. A gente não sabe o que é radiodifusão que não seja comercial. A imagem da TV pública sempre foi associada a péssima qualidade, limitação. O cenário que queremos é outro, com multiplicidade de interesses e de questões. Se tivermos um canal de saúde na TV aberta ou uma aliança mais clara com as TVs públicas, poderemos inclusive oferecer serviços do SUS (MURTINHO, 2013, p.15).

Desta forma os trabalhos de prevenção às doenças mais graves serão mais contundentes e hábitos tradicionais do cotidiano dos moradores das zonas rurais e ribeirinhas, comecem a mudar através da educação, higiene e que sejam criadas, políticas públicas voltadas, para ajudar a população a ter uma melhor qualidade de vida e prevenir-se da hepatite B e de outras doenças.

\section{Considerações finais.}

Durante a realização deste estudo foi possível compreender sobre a importância e oportunidade que o rádio tem de fundamental para ensinar os cuidados e a prevenção às pessoas que moram em lugares distantes da sede dos municípios amazônicos, onde a tecnologia moderna 
ainda é desconhecida pelos moradores. $\mathrm{O}$ aprendizado adquirido durante a pesquisa vinculada à importância do rádio como veiculo de comunicação e o lançamento da vacina no final da década de 1980, para a redução de pessoas contaminadas e levadas a óbitos pela a hepatite B trouxe-nos uma nova visão sobre a questão da saúde pública e a falta de compromissos dos políticos com comunidades isoladas da Amazônia brasileira.

Vale ressaltar a importância do Programa Social Bolsa Família, pois antes de ser lançado o programa social do governo Federal, os pais escondiam os filhos para não serem vacinados. Após o programa exigir que para receber o benefício às vacinas devesse estar atualizadas e registradas no cartão de vacinação, esse problema acabou sendo solucionado e passou a ajudar os agentes de saúde atingir um número muito maior de vacinados contra a hepatite B, durante as campanhas de vacinação. Desta forma os pais que a priori, evitavam levar seus filhos para serem vacinados, agora colaboram com os agentes, para que a vacina de seu filho esteja sempre em dia. E foi principalmente o rádio que se incumbiu de levar a informação desta condição às populações ribeirinhas, cumprindo seu papel de facilitar a mudança de hábitos em meio à democratização da informação.

\footnotetext{
A falta de informação sobre a prevenção da doença fazia com que muitas pessoas não autorizavam a vacinação dos filhos, pelo de muitos ficarem com febre e acabavam se embrenhando na mata para não ser vacinado, mas agora em função da bolsa família isso não acontece mais, pois para os pais receberem os benefícios e necessária esta em dia com a vacinação das crianças (Lima, 2012, entrevista).
}

Este trabalho tem uma importância social muito grande, pois valoriza o rádio como meio de informação nos lugares mais distantes da Amazônia, levando noticias de prevenção, vacinação, doenças, óbitos, avisos de familiares, enfim, a forma mais fácil de atingir a população isolada da nossa imensa Amazônia.

Desde já esperamos poder contribuir de alguma forma, com a prevenção da hepatite $\mathrm{B}$, valorizando as campanhas de prevenção, palestras nas escolas, alerta para os cuidados com o uso de utensílios alheios, uso de preservativos, cuidado com a água, cuidado com os destroços fecais, lava bem as frutas e verduras antes de ser ingerido, vacinar as crianças de acordo com o cartão de vacinação e se possível às pessoas que tiverem interesse em se tornar divulgadoras dos ricos e perigos que a hepatite $\mathrm{B}$, traz para a vida do cidadão, principalmente nesse contexto social em que já existe com mais frequência nas comunidades, além do rádio, também a televisão.

\section{Referências}

ADORNO, Theodor W, 1903-1969 Indústria cultural e sociedade. Seleção de textos Jorge Mattos Brito de Almeida traduzido por Juba Elisabeth Levy... [ et aI.]. - São Paulo Paz e Terra, 2002 .

BENSABATH, Gilberta. Vigilância Epidemiologia e Controle das Hepatites por Vírus: Resultados observados na região Norte do Brasil. In: Congresso da Sociedade Brasileira de Medicina Tropical, Salvador (BA), Anais de 06 a 11 de março de 1994, Sociedade Brasileira de Medicina Tropical suplemento IV, Pp. 237 a 240, 1994. 
COSTA, Alda Cristina Silva da. Et al. Indústria cultural: revisando adorno e horkheimer. In: Movendo Ideias, Belém, v8, n.13, p.13-22, jun 2003.

CUNHA, Euclides da. À margem da história. São Paulo: Martin Claret, 2006.

ESPARTEIRO, A. Marques, Catálogo dos Navios Brigantinos (1640 - 1910), Centro de Estudos da Marinha, 1976.

FONSECA. José Ferraz da. História das Hepatites Virais, Ver. Soc. Bras. Med. Vol. 43 n³, Uberaba, maio/junho 2010. Lisboa: Presença, 1973.

HOGGART, R. As utilizações da cultura. Lisboa: Presença, 1973.

LIMA, Antônia David Brito. Entrevista. Agente Comunitário de Saúde do Rio Purus desde 1988, nas comunidades da Laranjeira e Santa Rosa. 22 de jan. 2014.

MOULIN, Anne Marie. O Corpo Diante da Medicina. In: História do corpo. As mutações do olhar: $\mathbf{O}$ século XX/ sob a direção de Alain Corbin, Jean-Jacques Courtine e Georges Vigarello, Tradução e revisão Ephraim Ferreira Alves. 3 ed - Petrópolis, RJ: Vozes, 2009.

O LIBERAL. Pará, 30/05/2005. (Divulgando os perigos da hepatite b), entrevista com a médica sanitarista Gilberta Bensabath.

MURTINHO, Rodrigo. A comunicação não é vista como coisa pública. In: RADIS. Regulação da Comunicação não é Censura. 131 edição. Editora FIOCRUZ, agosto de 2013.

SCLIAR, Moacyr. História do Conceito de Saúde. Ver. Saúde Coletiva, Rio de Janeiro, 2007.

RELATÓRIO DO PRESIDENTE DA REPÚBLICA. Lançamento da Campanha de Vacinação Anti-Hepatite Tipo B. Lábrea, Amazonas. 31 de agosto de 1989.

RODRIGUES, Allan. S. B. e COSTA, Grace. S. A importância dos fatores socioculturais no processo da comunicação. In: Somanlu: Revista de Estudos Amazônicos da Universidade Federal do Amazonas. Ano 1, n. 1 (2000). Manaus: Edua/Capes, 2000.

SILVA, Antônio Carlos Galvão da. O Seringal no Município de Lábrea: o espaço vivido e a resistência de um tempo. São Paulo: Scortecci, 2012.

SILVA, Pedro Pires da. Retratos sul-amazônicos: fragmentos da história do Rio Purus. Editora: Scortecci. 1ª edição, São Paulo 2010.

Sites Consultados:

http://www.bauvelho.com.br/?p=2772 
http://conteudo.ebcservicos.com.br/programas/a-voz-do-brasil

http://www.ebc.com.br/nacional-am-55-anos/2013/05/gfdfg

http://humaitasomrural.blogspot.com.br/2011/01/marcia-ferreira-e-edelson-moura-tomam.html http://www.rederiomar.com.br/radioriomar/historia

http://www.sbt.com 


\title{
Amazônia: cultura, mídia e política pela ótica de um massacre
}

\author{
Mauro Antônio dos Santos (UNIR)
}

\section{Introdução}

Uma das mais constantes contradições na produção literária e histórica da Amazônia é o adjetivo a ela referido que vai de paraíso a inferno. Tais adjetivos incorporados pela literatura e popularizado pelos seus exploradores já é uma demonstração da sua singularidade cultural. Sendo a Amazônia uma das primeiras regiões do Brasil a ser explorada pelos europeus e uma das últimas a resistirem à investida dessa exploração.

O meio amazônico impõe sua condição. Sem ferir os méritos da brilhante obra de Arendt (2007), "A Condição Humana", com todos os elementos constitutivos da natureza humana que adquiriu no seu fazer histórico, da vida terrena à conquista do espaço, a única forma, mesmo mudando para um outro planeta, o homem jamais se livrará da sua condição de humano, a Amazônia também impõe sua condição aos seus habitantes. Euclides da Cunha em pleno século XX faz uma descrição dessa natureza como se estivesse num estágio da própria evolução. "Realmente, a Amazônia é a última página, ainda a escrever-se, do gênese" (CUNHA, 2003, p. 354). Ao afirmar que o homem era nada mais que um estranho nessa natureza, incapaz de amansá-la, colocando à margem da história, a história do progresso, do desenvolvimento, do capitalismo, da cultura ocidental. O massacre é o choque cultural, resultante da política de colonização que desde os grandes aventureiros colonizadores, tentam adaptar a Amazônia ao mundo e não o mundo na Amazônia, ou, ao menos, a Amazônia para a Amazônia. Assim sempre foi apresentada pela mídia ao mundo como um espaço vazio à espera de seus exploradores e, através da indústria cultural, o símbolo da modernidade ocidental, se desenvolveu o maior projeto de ocupação da Amazônia norteado pela capitalização da terra que se transformaram na indústria da grilagem de terras e na expropriação dos nativos e caboclos.

E assim ainda entram para a história como os heróicos pioneiros, os quais se tornam símbolo do desenvolvimento da região, mesmo quando usa a força, por exemplo, o conflito de Corumbiara que tem todas as características dessa ocupação.

\section{A Amazônia}

O descobrimento da América como condição e consequência do pensamento moderno, juntamente com a contra reforma e as técnicas de navegação, principalmente a que possibilitou a mapear a rota pelos astros, são destaques das reflexões de Arendt, mas é com Gondin (1994), com o livro a "Invenção da Amazônia", a qual faz um resgate do pensamento ocidental entre a decadente cultura medieval e a emergente cultura moderna onde os avanços das técnicas de 
produção propiciam as invenções da arte de navegação, tornando uma constante, as aventuras ao fim do mundo que, as quais deveriam trazer respostas comprobatórias ao mundo científico e cultural da época, embalado pelos ideais iluministas, entretanto passa a abrir um fosso intransponível ao pensamento ocidental no tocante a reconhecer quaisquer "verdades" que não encaixassem na sua visão de mundo. "Abrir mão dessas prerrogativas era negar a própria identidade europeia, já que as representações do outro foram fundamentadas na tradição europeia greco-romano-ibérica-renascentista”. (PONTES, 2000, p. 5).

Então, de que maneira o olhar do habitante do Velho Mundo veria o Novo se entre os dois ainda persistia a crença da inabilidade da zona tórrida, da inexistência de uma raça única com suas variáveis culturais e étnicas, fauna não embarcada na arca de Noé, flora não alagada pelo dilúvio, os rios já mais citados pela bíblia? (GONDIM, 1994, p. 37).

A condição como foi apresentada ao mundo europeu, foi elaborada de cabeça para baixo, o mundo é que foi apresentado à Amazônia e não a Amazônia ao mundo. É a tentativa da sua inversão histórica. Aos aventureiros das grandes navegações, são atribuídos as honras e méritos, não por causa das novas descobertas, pois essas apontavam as fissuras de suas crenças, o pensamento hegemônico ocidental, mas pela coragem e ousadia de enfrentar os monstros do novo mundo. Tais aventureiros, entretanto, se deliciavam de tal empreitada, pois estavam sujeitos a encontrar o paraíso bíblico, o jardim do Éden, a fonte da vida existente no mundo europeu? Ou no mínimo, as riquezas neles existentes. Estes se legaram a dar as notícias do mundo desconhecido e os cronistas legaram o papel de justificar a vida existente fora do pensamento europeu blindado pela verdade cristã, transformando ao longo de cinco séculos a história dos povos milenares do novo mundo na sua subcultura, ou seja, uma cultura inferior, a ser civilizada.

A riqueza dos rios amazônicos está na promoção de sua subsistência, numa harmonia geradora da vida e da cultura dos nativos vista pela cultura europeia como vida miserável e infiel. Os ataques ao seu modo de vida, à sua cultura e sobre as riquezas da floresta, se deram, primeiramente com as missões religiosas, com os aventureiros e depois com os bandeirantes sertanistas em busca de mão de obra para trabalharem como escravos nas fazendas do nordeste açucareiro. Junto a essa força brutal destruidora da cultura, veio a dizimação em massa com as epidemias trazidas pelos europeus e, sobre tudo, da ação violenta dos colonos em ataques as suas comunidades tribais que, forçaram o deslocamento de grande parte dessas populações ribeirinhas para o interior da floresta.

Tudo isso foi destruído a uma velocidade espantosa. As populações que sobreviveram fugiram do contato europeu, internando-se nas altas cabeceiras dos rios afluentes ou migraram para o interior, transformando os seus modos de vida e adaptando-se a um novo ambiente, a terra-firme. O habitante atual da várzea, possível herdeiro da cultura indígena de várzea, constitui a maior parte da população rural da Amazônia (PEREIRA, 2007, p. 12).

Essa autodefesa dos povos ribeirinhos, através de fugas para o interior, abre caminhos pelo quais, sobre seus rastros seguem os exploradores e colonos floresta adentro, com a exploração de vegetais até a descoberta do uso capitalista do látex da seringueira. É o principio de uma mudança não somente radical da cultura ribeirinha, mas da cultura camponesa de todos os estados do Brasil, mudança radical da geografia, da economia, do clima e principalmente o meio ambiente, que ocorreu aceleradamente a partir da segunda metade do século XX. 
Esta é a Amazônia majestosa, que vai absorvendo os delinquentes de seu sistema físicos, atraídos, alguns, pelas riquezas, outros, pelas curiosidades cientificas e grande parte pela necessidade de fugir da proletarização moderna do centro sul do país.

Figura 1: - Em busca do sonho.

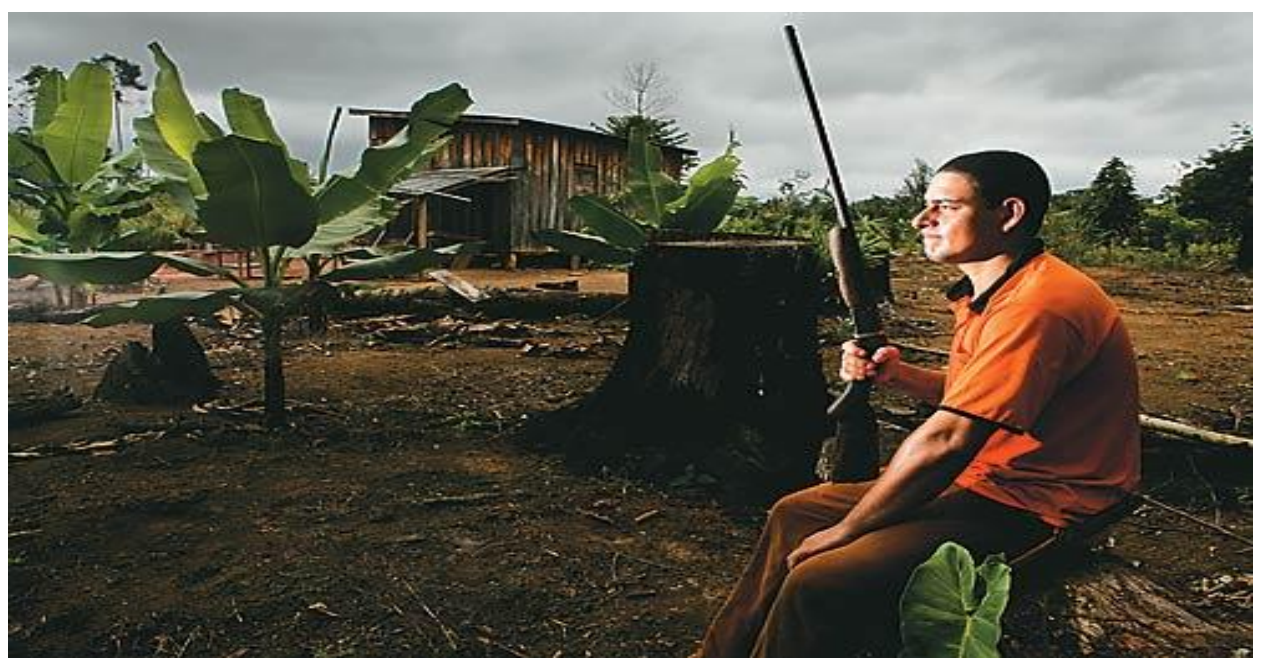

Fonte: Revista Veja, 2009.

A imagem acima apresenta o gaúcho Alceu Santos de Almeida, de 35 anos, é um exemplo de brasileiro que vê a Amazônia como um eldorado. Há cinco anos, ele deixou a cidade de Palmeira das Missões, atraído pela possibilidade de comprar um pedaço de terra em Rondônia por um preço muito mais baixo do que no Rio Grande do Sul. Adquiriu um sítio de 100 hectares de mata bruta. Com 400 reais, alugou um motosserra e jogou no chão quase 5 hectares de floresta. No lugar, ergueu um casebre de madeira e montou uma roça de milho, arroz e feijão, que ele lavra aos sábados e domingos. "De segunda a sexta-feira tenho de trabalhar na serraria", explica Alceu. Toda vez que vai à sua propriedade, carrega a espingarda para assegurar a carne da semana. Garante que caça apenas o suficiente para sua família comer. "Só os animais saborosos, como pacas, veados e queixadas", informa. Grifo do autor. (REVISTA VEJA ESPECIAL, 2009, p. 20). 
Figura 2 - A vida no laço.

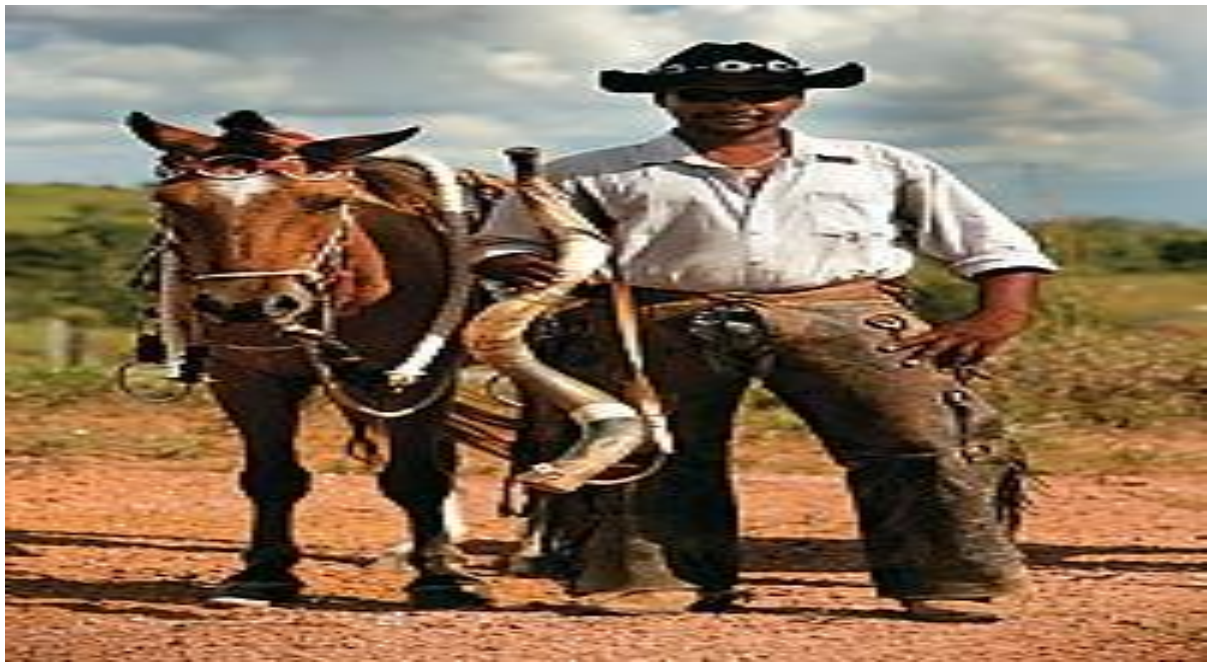

Fonte: Revista Veja, 2009.

O vaqueiro Edilson Ferreira de Oliveira, de 31 anos, nasceu no Paraguai, país onde seu pai exercia a mesma profissão trabalhando para os brasiguaios. Morando na Amazônia há mais de vinte anos, trabalha acima de treze horas por dia, seis dias por semana. Com um salário de 900 reais mensais, ele se diz um vitorioso. "Tenho um emprego bom e uma renda que me permite viver com dignidade", vangloria-se. Junto com amigos, ele tem sob sua responsabilidade um rebanho de cerca de 1000 animais na cidade de Monte Negro, em Rondônia. "Depois que cortar madeira virou crime, o boi se tornou o melhor negócio daqui", diz o vaqueiro, que carrega cachaça no cantil e prepara suas refeições todos os dias no meio do pasto. Grifo do autor. (REVISTA VEJA ESPECIAL, 2009, p. 22).

Assim o desenho real da história da Amazônia se revela hoje pelo sonho da terra de seus colonos e se desloca para o trabalho nas madeireiras, que se desloca para a criação de gado, onde ambos os aspectos só combina com latifúndio na contramão de projetos ecológicos. Todo o aspecto que a floresta acionou para se manter integra, como anunciada pela veja, mata insalubre, animais peçonhentos, impaludismo e até mesmo as tribos indígenas em defesa de seus territórios, não foram suficientes. Então a Amazônia concebe em seu ventre-inferno verde os mais variados aventureiros em busca do paraíso com suas diversidades culturais e aguarda pela a amálgama dos frutos sociais da sedutora Amazônia brasileira.

\section{A cultura}

\subsection{O caboclo}

A canonização do termo caboclo, mesmo sendo um arcabouço da identidade do homem amazônico, a sua origem em Euclides da Cunha, com o livro "À margem da história", autor que "contribuiu para a formação de um pensamento social no Brasil, iniciando-se verdadeiramente com ele uma maneira cientifica de interpretar a sociedade” (GONDIM. 2004, p. 222). Euclides da Cunha prossegue sobre a mesma visão dos cronistas exploradores que tem o nativo como o estorvo no paraíso, é o elemento que desarmoniza a sociedade instalada pelo branco (GONDIM, 2004, p. 133). O povo que está à margem da história é o nordestino, os nativos e mestiços não são chamados a integrar um projeto de identidade da nação brasileira. 
O resgate do nordestino que está fora da sociedade brasileira é proposto por Euclides através de uma reforma agrária, através da agricultura, é o projeto de integração nacional em que as atividades extrativas se transformassem em atividades produtivas. É o primórdio da mudança do eixo das relações sociais do inicio do século XX que tem o rio como elemento edificador do ethos cultural, que se molda com o meio, no caso do Caboclo-Ribeirinho da Amazônia, o modo de vida se fundamenta intimamente nessa relação com o rio, pois são meios de subsistência, transporte e símbolo cultural. Fraxe (2004, p. 20). Mudança concretizada para a floresta, com o início da abertura de estradas, no meado do mesmo século, como a Belém-Brasília, transamazônica e especificamente a BR 364 que transformou Rondônia num espelho dessa mudança com dois tipos de colonização agrícola, a oficial e a espontânea.

A dinâmica das relações de produção imposta pela economia da borracha, princípio das mudanças das relações socioculturais, mesmo tendo a floresta como instrumento de produção, no caso a borracha, a castanha e o caucho, os nordestinos e nativos criam a identidade ribeirinha. Essa lógica está relacionada ao modo de vida do ribeirinho que tem uma relação muito forte com seu local, e seus hábitos, suas crenças, pois segundo Fraxe (2011, p. 123) "a construção de um lugar revela-se com a construção de uma identidade". A construção desse processo de pertencimento ao lugar é reveladora dessa relação de vida estabelecida com o local vivido e expressado pelo mundo simbólico dotado de significados próprio expresso pela riqueza dos mitos amazônicos que dão sentido ao estado de ser do caboclo da Amazônia.

O que faz do caboclo da Amazônia se diferenciar do mulato nordestino, um forte, de Euclides da Cunha em "Os sertões", ou o caipira do sudeste é exatamente o local, o lugar vivido. Enquanto o caipira e o "cabra" forte do nordeste sofreram a ocupação massiva do europeu, durante cinco séculos, diariamente sua identidade cultural ia sendo usurpada e confinada aos latifúndios da monocultura, já caboclo resistiu criando o mundo na medida a sua volta, buscando desvendar os segredos de seu lugar, reconhecendo a mitos, lendas, plantas medicinais, rezadeiras, celebrando a vida nas festividades e danças originais, curando-se de suas doenças com as plantas e ervas das florestas. As relações de produção camponesa, principalmente os da Amazônia, no seu cotidiano, produzem um estilo de vida econômico ambientalmente sustentável pela cultura tradicional de suas roças, da caça, e da pesca expressos, sobretudo por seus hábitos alimentares que acompanham o fluxo das águas, dos frutos e dos animais.

A invisibilidade da cultura nativa já declarada nos primeiros registros dos colonizadores e ao longo da formação histórica da colonização portuguesa, posteriormente testemunhada nas disputas para a criação da identidade da nação. O Brasil surgido das contribuições culturais dos negros escravos, dos nativos indígenas e dos brancos colonizadores, forjaram a identidade literária e invisibilizaram a autêntica identidade cultural que tem suas raízes sobre a terra. Fato verificado com o projeto de integração da Amazônia ao sul do país durante o século XX. Com a proposta de transformar a economia extrativista em economia agrícola, provocou a corrida de uma grande leva de famílias que se viu próximo de realizarem dos sonhos; voltar as suas raízes com a terra; e se ver livre do ataque dos latifundiaristas e capitalistas inescrupulosos do sul país.

O pensamento moderno, moldado pela indústria cultural, encontramos nas páginas da revista veja sua opinião a cerca da vida do caboclo, analisando a migração a partir da década de 60, somados aos indígenas e os que aventuraram nos ciclos da borracha, na construção da ferrovia, junto soldados da borracha, mesclaram-se para formar um "Homo amazonius", o brasileiro adaptado à região. Estas relações, homem e natureza forjam na Amazônia uma nova 
cultura hipertrofiada da cultura camponesa, aqui descrita no sentido da tradição de vida das famílias que dependem das relações de produção diretamente com terra e com ela criam vínculos de sobrevivência nos moldes do centro sul do país, de onde são oriundos em grande maioria, os quais, tais modelos de sobrevivência, são totalmente incompatíveis aos solos amazônicos. É forjado a criar novas formas de sobrevivência, moldando a cultura camponesa na Amazônia. Mas não são estes os empecilhos na manutenção da cultura camponesa hipertrofiada e sim a dialética da própria história com suas contradições nas relações de produção econômica, política e social da vida pós-moderna, que ADORNO (2002), chama de Indústria Cultural. A revista veja aponta em que direção segue os povos da Amazônia:

\begin{abstract}
A exuberância da natureza contrasta com a qualidade de vida dos amazônidas. A imagem idílica do caboclo que vive no paraíso tropical e nele quer permanecer só tem correspondência com o mundo real na imaginação de quem vive longe dali. Mesmo aquele que mora em pontos distantes, só acessíveis por barcos, assiste às novelas em televisores com antenas parabólicas e energia elétrica proveniente de geradores a óleo diesel. É natural que queira viver com os confortos modernos presentes no Sudeste, e não como uma relíquia viva do século passado. $\mathrm{O}$ ribeirinho, assim como o índio em sua aldeia, prefere cozinhar em fogão a gás, nem que para isso precise pagar por esse conforto com bens retirados da floresta. Em áreas rurais, a ausência de comércio e de dinheiro faz do escambo uma forma corriqueira de abastecimento da população [...] As soluções que propõem manter o homem no mato, sem possibilidade de progresso pessoal, mostram resultados pífios. Grifo nosso. (REVISTA VEJA, ESPECIAL. 2009, p. 24).
\end{abstract}

A cultura cabocla, caipira, camponesa que se contrapõe ao capitalismo, a muito esquenta debates sobre sua sobrevivência, se, se mantêm pura ou passa a fazer parte integrante do capital. Entretanto, o que vale externar é que ela está na contramão das estatísticas modernas, ou seja, sua forma ou meio de vida está sendo devorada pelos meios mais desenvolvidos? A cada dia, a cada estante, em um piscar de olho você perde uma oportunidade e pode estar fora da marcha do capitalismo e isto significa fora do emprego, fora dos estudos, fora da comunidade, fora da sociedade, até parece estar fora da própria vida. Porque a vida pós- moderna é constituída pelo recipiente do momento. Passa a ser medida pelo seu volume, é liquida nas palavras de: Bauman:

O passado tende a ser destruído de modo incansável e sistemático, tornando praticamente impossível a redenção das esperanças, de modo que os indivíduos "são reduzidos à mera sequencia de experiências instantâneas que não deixam traço, ou então cujo traço é odiado como irracional supérfluo ou 'suplantado' no sentido literal do termo". [...] "O que aconteceu na vida de todos é submetido a uma contínua transformação na memória e com muita frequência ganha as características de um paraíso perdido, cada vez mais bizarro e estranho." Quase tudo que se possa dizer para tentar transmitir a condição amorfa e vagamente ameaçadora do exilado também pode ser dito de todos os outros homens e mulheres expostos à nova paisagem urbana líquido-moderna. Grifo nosso. (BAUMAN. 2008 p. 175 e 179).

A cultura camponesa, que os acampados de Corumbiara sonhavam e sonham os seus sobreviventes, assim também como sonhava Marx, se depara com o muro da mão invisível do capital, nas armadilhas do consumo capitalista que delineia o futuro das culturas das sociedades amazônicas que tem como base de sobrevivência a relação direta com a natureza como as tribos indígenas, ribeirinhos e pequenos agricultores familiares. Retomando a relação cultural pósmoderna e as narrativas acadêmicas que relatam o episódio do massacre, observam-se duas tendências intrigantes da cultura ao longo da nossa história, relatadas nas teses de Marcio e 
Helena $^{1}$. A primeira consiste na insistência da manutenção de uma cultura camponesa expressa pelas lutas das inúmeras organizações de pequenos agricultores com, ou, sem terras, ideologicamente sustentado pelas ideologias marxistas e leninistas que tem como base a o combate ao sistema de poder capitalista burguês. A segunda consiste numa estatística trágica para a nossa história que é a repetição dos atos de massacre que vai desde os tempos coloniais à república. Desde o Contestado, Canudos, Corumbiara a Eldorado dos Carajás, como que se fosse uma forma cultural brasileira de resolver as questões sociais ligadas à questão da terra? Não levando em conta as estatísticas de mortes isoladas, assim naturalmente dizendo, como se fosse normal esses conflitos no campo, se já não o é? Como assim nos acostumamos com a vida cultural das favelas, da vida cultural dos meninos, meninas, adultos e velhos a perambularem pelas ruas das cidades. Se esta prática se repete ao longo dos séculos, é sinal de que aceitamos como cultural as práticas utilizadas pelo Brasil para resolver suas contradições sociais, ceifando a vida de milhares de pessoas e construindo uma cultura da violência e do terror, que permaneceram nas famílias dos sobreviventes que sofrem a violência da desesperança, a violência da vida debaixo de barracos de lonas, da violência dos despejos em que a força militar agem preparados como se estivessem frente a um campo de batalha como se fossem ferozes inimigos da pátria. Mas a luz no fim do túnel se ascende com os novos paradigmas dos estudos culturais sobre a visão de conceito pós-colonial que propõe a desmitificarão e deshierarquização propiciando a desconstrução dessa visão de poder hegemônico central ao garantir ao menos vozes ao outro, conforme descreve Prysthon:

Contrastados com disciplinas mais tradicionais como História da Cultura, Antropologia, Teoria Literária, os Estudos Culturais, especialmente a partir dos anos 90, forneceram um ponto de vista muito mais abrangente — sendo simultaneamente bem específico na sua historicidade-, condensaram um instrumental capaz de dar conta da contemporaneidade de maneira desmistificadora e des-hierarquizada e serviram como ponto de partida para o estabelecimento de uma política da diferença que buscava desafiar a hegemonia nordocêntrica, redefinir a modernidade a partir de novos termos, apontar alternativas para um padrão cultural baseado na cópia e na imitação e garantir voz a sujeitos. (ANGELA PRYSTHON, 2010, p. 12).

O massacre também se tornou símbolo da luta da cultura camponesa, símbolo dos que buscam viver sobre suas raízes com a terra e também como alerta da eminência à expropriação dos que já possuem suas terras e mantém uma forma de vida oposta ao modelo de vida capitalista do pensamento ocidental.

\section{A mídia}

As pesquisas que retratam o histórico do massacre, assim como a própria narrativa dos sobreviventes, são categóricas em afirmar que o fato teve uma cobertura expressiva da mídia. $\mathrm{O}$ que se define aqui por mídia, requer como atualidade as definições simplesmente como instrumentos de sustentação da forma de poder dominante vigente na sociedade atual em que Adorno (1903-1969) e Horkheimer (1895-1973), analisando a relação entre cultura e ideologia da sociedade, conceituou como indústria cultural. A apropriação dos meios de comunicação de

\footnotetext{
1 Márcio Marinho Martins e Helena Angélica de Mesquita, são pesquisadores da história dos movimentos sociais de Rondônia, com trabalhos sobre o massacre de Corumbiara, os quais serviram de base para a escrita deste artigo. (Ver bibliografia).
} 
massa pelo poder dominante transformou a vida cotidiana num verdadeiro espetáculo, onde a economia, a política e a organização social passaram a ser um refém, por opção, da sedutora alienante. Seus sustentáculos cobrem toda vida social. como Douglas Kellner analisa a sociedade atual:

\begin{abstract}
Nas últimas décadas, a indústria cultural possibilitou a multiplicação dos espetáculos por meio de novos espaços e sites, e o próprio espetáculo está se tornando um dos princípios organizacionais da economia, da política, da sociedade e da vida cotidiana. A economia baseada na internet permite que o espetáculo seja um meio de divulgação, reprodução, circulação e venda de mercadorias. A cultura da mídia promove espetáculos tecnologicamente ainda mais sofisticados para atender às expectativas do público e aumentar seu poder e lucro. (KELLNER, 2004, p. 5).
\end{abstract}

É uma constante dos movimentos sociais se manifestarem contra as formas em que a mídia retrata sua causa, e, no entanto, injusta, pois apenas cumpre seu papel a que lhe é incumbida no dominó do capitalismo, uma vez que tem como carro chefe o discurso da livre iniciativa e da democracia burguesa, mesmo que ela seja um veículo de poder. Muito além de ser aparelho de hegemonia no conceito de Gramsci, a mídia só se interessa pela veiculação do espetáculo se, o mesmo cumprir a meta objeto que é o lucro a ser consumido pela audiência. Quanto mais impactante for a dramatização dos atores do espetáculo, mais audiência terá o show e o lucro se avalia pela audiência, do regional ao nacional. A mídia se fez presente no massacre de Corumbiara e expôs mais do que uma forma desigual de confronto, de um lado policiais fortemente armados contra homens, mulheres e crianças com foice, facão e espingardas velhas, um filme perfeito, ao invés de mocinhos e bandidos, poderosos e indefesos, pobres sem terra da Amazônia, sendo esmagados numa região com um vazio demográfico e uma superfície territorial de 5.035.747,80 km2, (61,2\% do Território Nacional). A questão é o espetáculo que teve audiência internacional em que o mundo estava vendo, quase, em tempo real o terror.

A mídia cumpriu seu papel de cobertura, transmitiu o espetáculo, um filme de terror, que teve grande audiência e que não cabe aqui julgar seu papel social, mas fazer uma analise da forma em que os movimentos sociais se apoderaram da repercussão midiática do fato em defesa de seus princípios ideológicos de poder. As contradições, própria do sistema capitalista, propiciam também elementos que devem ser utilizados em sua oposição, principalmente através da própria mídia que hoje desponta como principal aparelho hegemônico do poder dominante, na propagação da ideia de que indivíduos se conforme com a organização vigente, "mas também lhes oferece recursos que podem fortalecê-los na oposição a essa sociedade" (KELLNER, 2004, p. 12).

Os camponeses sobreviventes ao massacre, criaram um site de mídia eletrônico chamado de Movimento Camponês Corumbiara e o Instituto Adelino Ramos, os quais utilizam para divulgarem as atividades do movimento. A forma utilizada da repercussão do fato pelo movimento é mais bem identificada na reação política do poder do estado em que se preocupou com a sua imagem no sentido de se manter no controle do estado através de pleitos futuros.

\title{
5. A política
}

O encontro entre o camponês e o capital, que produz o deslocamento, recebe a denominação de encontro de fronteira, na qual o capital passa a ser o símbolo do pioneirismo e os expropriados da sua ação, formam a frente de expansão. O sertanejo, o caipira, o camponês, 
do nordeste, sudeste ou sul, símbolo da cultura miscigenada e da identidade brasileira, vão se transformando no pelotão da frente de expansão, descendo pelo centro-oeste brasileiro até chegar na Amazônia, que logo recebe um novo pelotão, agora, uma unanimidade do centro sul, chamada de frente pioneira. Essa, a frente pioneira, se destaca ou pelo seu poder econômico ou pelo seu poder de alienação junto ao capital e da mesma forma, expropria os nativos e os caboclos da Amazônia.

O espaço amazônico desde os primórdios da sua colonização concebeu uma política ligada diretamente à Europa em uma relação caracterizada pelo exotismo e assim permaneceu praticamente por quatro séculos, diferentemente do restante do Brasil onde se efetivou a colonização portuguesa a partir do século XV. Enquanto o restante do país se desenvolveu sustentado pelos seus ciclos econômicos: do pau-brasil, do açúcar, do ouro e principalmente do café (MARTINS, 1988, p. 103 e 104), a Amazônia preservou seu modelo de vida econômica extrativista até o período militar nas décadas finais do século XX.

Em Rondônia o projeto político do progresso se daria através das empresas agrícolas e os projetos de colonização oriundos do PIN - Projeto de Integração Nacional que, em Rondônia se transformaria através de um processo extremamente acelerado de economia extrativista mineral e florestal, para uma economia de base agrícola. (CEMIN, 1992, p. 54). Pelo poder político do regime militar, o progresso é arquitetado sobre as fronteiras da Amazônia, através da disfarçada colonização oficial que, inicia com a extinção da Superintendência do Plano de Valorização Econômica da Amazônia - SPVEA e sob o discurso da "Operação Amazônia" e a criação, em 1966, da Superintendência do Desenvolvimento da Amazônia SUDAM, que, entre os seus principais objetivos estava a transformação da economia Amazônica - extrativista para agropecuária - e o fortalecimento de suas fronteiras, capitalizando a terra.

Outro fator político e econômico que promoveu a colonização no Território de Rondônia foi a construção da Linha Telegráfica por Rondon entre os anos de 1907 a 1915 e a descoberta de cassiterita na região de Ariquemes que levou o presidente JK a abrir a rodovia BR-29, posteriormente chamada BR-364, possibilitando a ligação de Brasília a Porto Velho, via Mato Grosso. Estes fatores contribuíram para a efetivação de uma colonização espontânea (IANNI, 1979, p.19), evidenciada no reflexo populacional que quase dobrou seu quantitativo populacional entre 1950-60² e no acréscimo de 53\% no intervalo de 1960/1970. Esse projeto político do Estado permitiu o avanço do projeto político social de enfrentamento, como percebido por Martins:

\footnotetext{
Na verdade e no fundo, o aumento da violência no campo não envolve apenas o problema da terra, o desejo de ter um pedaço de terra para sobreviver por conta própria. Quem pensa assim esta enganada. Desde os anos quarenta a violência vem crescendo em decorrência justamente da recusa crescente dos trabalhadores rurais em aceitar formas antigas de dominação pessoal, a chamada violência institucional representada pela falta de direitos políticos e sociais. (MARTINS, 1991, p. 47).
}

A política do poder estatal através de três polos distintos - Concorrência Pública, Regularização Fundiária e Colonização - estruturou a questão agrária, principalmente pelo Programa de Redistribuição de Terras e de Estímulo à Agroindústria do Norte e Nordeste PROTERRA, criado em 1971, que tinha como principais objetivos: criar condições de emprego no campo, fomentar as agroindústrias nas regiões de atuação da SUDAM e da SUDENE dando

\footnotetext{
${ }^{2}$ Fonte: IBGE, Anuário Estatístico do Brasil de 1987.
} 
crédito agrícola e fornecendo empréstimos aos projetos de colonização particulares e dar assistência técnica à modernização das propriedades rurais através do BASA e do Banco do Brasil. Desta forma favoreceram os projetos Fundiários estruturando o avanço da fronteira econômica e da ação do capital.

Os beneficiários do PROTERRA foram, no entanto, majoritariamente produtores do sul que venderam suas terras para adquirir áreas bem maiores nos projetos privados do programa (FILHO, 1996, p. 21). Os projetos tinham como objetivo resguardar a posse da terra sob o domínio do Estado Nacional e, ao mesmo tempo, disponibiliza-la para a ação das empresas capitalistas que almejavam investir no estado.

As áreas constituídas nos processos de licitação pública foram destinadas a projetos de desenvolvimento econômico, ligados ao grande capital, como a Gleba Burareiro (produção de cacau); Gleba Garça (produção pecuária de leite e corte); Gleba Corumbiara (produção pecuária de corte) A área reservada à colonização foi de 128.636 há, enquanto as áreas de regularização Fundiária e Concorrência Pública abrangeram uma área de 49.504.320 ha. Isto confirma que o governo, através de seus programas, apesar de ser interlocutor de um discurso político em que convocava os trabalhadores rurais a colonizarem a Amazônia através da obtenção de pequenas propriedades, criando novas fronteiras, em verdade praticava a distribuição de latifúndios para empresas capitalistas nacionais e internacionais.

A partir disso, é possível concluir que os programas e projetos políticos e econômicos do governo, promoveu o encontro das fronteiras entre o latifundiário e o sem terra, entre o capital e a cultura, entre a vida e a morte, simbolizada pelo Massacre de Corumbiara.

Apesar da colonização de Rondônia ter iniciado no século XV como toda a Amazônia, somente no final do século XIX e inicio do século XX, com o primeiro e segundo ciclo da borracha é que se formalizam as primeiras mudanças nas relações sociais verificadas na região ao longo da bacia do Madeira-Guaporé. $\mathrm{O}$ encontro nessa fronteira se dá de forma violenta, principalmente com os nordestinos subtraídos da sociedade como subclasse, são os primeiros a construir a frente de expansão na Amazônia.

\footnotetext{
Quando as grandes secas de 1879-1880, 1889-1890, 1900-1901 flamejavam sobre os sertões adustos, e as cidades do litoral se enchiam em poucas semanas de uma população adventícia de famintos assombrosos, devorados das febres e das bexigas a preocupação exclusiva dos poderes públicos consistia no libertá-las quanto antes daquelas invasões de bárbaros moribundos que infestavam o Brasil. Abarrotavam-se, às carreiras, os vapores, com aqueles fardos agitantes consignados à morte. Mandavamnos para a Amazônia — vastíssima, despovoada, quase ignota - o que equivalia a expatriá-los dentro da própria pátria. (CUNHA, 1922, p. 54 e 55).
}

A façanha do Marechal Rondon é o principio da construção simbólica do pioneirismo no imaginário da sociedade rondoniense suplantado pela estratégica militar, ${ }^{3}$ aliciada pela ação dos soldados da borracha e concretizada sobre os projetos dos governos militares. A crise do ciclo da borracha em meados do século XX, é o referencial dessa mudança numa combinação em dois polos: estratégia militar de fronteira e o discurso de colonização. $\mathrm{O}$ primeiro polo se dá pelo discurso de fronteira como espaço geográfico e segurança nacional que passa a ser uma ação constante a partir das viagens de Euclides da Cunha, com Getúlio Vargas, onde em 1943 cria o Território do Guaporé, atual Estado de Rondônia, com os militares e com

\footnotetext{
${ }^{3}$ Artigo:A colonização em Rondônia: imaginário amazônico e projetos de desenvolvimento - tecnologias do imaginário, dádivas-veneno e violência. Arneide Bandeira Cemin.
} 
os governos pós ditadura com a criação do Projeto SIVAM. O segundo polo direciona, a principio ao contingente subversivo questionadores da ordem imposta, os sobreviventes das secas no nordeste, os sem terra, através do discurso de efeito político de Vargas com a marcha para o Oeste; já os militares co a terra sem homens para homens sem terra, que ocupava os meios de comunicação. Por fim aos homens de bens através dos empresários da colonização, dos latifundiários do agronegócio a partir da segunda metade do século XX.

$\mathrm{Na}$ nova colonização, o poder do Estado sobre as sombras do capital, criam os heroicos pioneiros, e assim todos se sentem através de mil histórias de heroísmo e em todas elas está presente a luta contra os índios, os mosquitos, as casas de pau a pique e principalmente as onças e gogo de sola.

A frente pioneira representada pelo paulista ou sulista, sob o poder do capital criou os símbolos que imortaliza a memória do colonizador: a cidade, ou, o primeiro armazém da cidade, a primeira igreja, a primeira escola, o primeiro carro, o primeiro rádio, a primeira TV, o primeiro agente do INCRA, o primeiro banco, o primeiro deputado, a primeira serraria, a primeira trilhadeira ${ }^{4}$, o primeiro latifúndio, a primeira farmácia e seus padrinhos cordiais, o primeiro professor, o primeiro advogado, o primeiro farmacêutico e o primeiro fazendeiro.

A mudança provocada pelos projetos de colonização também tem seus reflexos na esfera política do Estado de Rondônia, a partir da década de 1990, o poder dos fazendeiros, do centro sul do estado, representantes do latifúndio e do agronegócio da madeira, da soja e do gado se revezam na condução da política de governos e permanecem até os dias atuais.

O massacre de Corumbiara, envolve figuras desse poder econômico e político, entre os o fazendeiro, Almir Lando do PMDB, figura política em Rondônia desde o ano de 1982. Suas terras localizam na mesma região do massacre dos camponeses, entretanto, seu envolvimento está relacionado desde o conflito com os índios através do sertanista Vicente Carelli e Marcelo dos Santos, este último, chefe da Funai que conta dez anos de trabalho documentado, (19861996), da Equipe da Frente de contato Guaporé, na gleba Corumbiara, em busca de uma imagem que provasse que a região, eram terra indígena dos grupos que, mais tarde foram registrados como Kanoê e Akunt'su, da reserva do rio Omerê. O mesmo documentário registrou a imagem de um único indio, que foi chamado de "índio do Buraco" que deu origem a criação da reserva Tanaru. O "Índio do Buraco", não aceitou fazer nenhum tipo de contato com a Frente de Contato do Guaporé, porem, a história da sua presença na região é tão conhecida quanto a dos Kanoê. As evidencias e estudos dos fatos levam a crer que seu povo sofreu genocídio pelos fazendeiros da região, conforme é descrito por Monte Reel:

Entre os tantos fazendeiros "prejudicados" por Marcelo, um é muito poderoso. Além de ser advogado tarimbado, o fazendeiro em pauta detém um mandato de senador de Republica. Amir Lando seria o dono de 4 mil hectares de terra em Corumbiara, onde moram dez índios. (REEL, 2011).

Acrescenta-se a este fato, ou ao menos induz a uma diretriz que possa expressar sociologicamente a ação política no massacre, uma outra figura desconhecida dos camponeses na época e que tinha poder de comando exercendo o cargo de secretário de justiça no estado na época e que hoje é o governador do estado de Rondônia o excelentíssimo Sr. Confúcio Moura

\footnotetext{
${ }^{4}$ Trilhadeira é o nome popular de uma máquina que pode ser puxada por animal, ou trator, movida por um pequeno motor a diesel, ou pela polia do trator e que era usada para retirar o arroz do cacho depois de estar empilhado.

Quase todos os donos de trilhadeiras se tornaram grandes atravessadores.
} 
do PMDB, fazendeiro na região de Theobroma e Ariquemes, uma de suas fazendas foi ocupada e negociada com o INCRA para ser objeto de assentamento da reforma agrária.

\section{Considerações finais.}

A Amazônia que sempre teve o dom de impressionar os seus viajantes, na frase de Euclides da Cunha, que populariza também a cultura cabocla, através da política de colonização dos governos militares, ao transformar a economia extrativa em economia agrícola em Rondônia, promove uma das maiores mudanças cultural da Amazônia, sustentada pelos sistemas que dá vida ao progresso e a modernidade. A cultura nativa foi suplantada pela mídia na medida em que se implantam os símbolos da colonização na figura do pioneiro, resultado do conflito que se originou dos desencontros da cultura do sul do país e teve, e continua a ter, como resultado, massacres no encontro dessas fronteiras na Amazônia.

\section{Referências}

ADORNO, Theodor; W. \& HORKHEIMER, Max. Dialética do Esclarecimento: Fragmentos Filosóficos. 1947. Disponível em: http://antivalor.vilabol.uol.com.br

AMAZÔNIA. O fator humano. Veja especial. 2009. Disponível em: $<$ http://veja.abril.com.br/especiais/amazonia/>

BAUMAN, Zygmunt. Identidade. Rio de Janeiro: Zahar, 2006.

KELLNER, Douglas. A cultura da mídia e o triunfo dos espetáculos, LÍBERO - Revista do Programa de Pós-Graduação da Faculdade Cásper Líbero. ISSN: 1517-3283. SP, vol. 06. 2004

CUNHA, Euclides Da. À margem da história. São Paulo: Martins Fontes, 1999.

IANNI, Otávio. Colonização e contra-reforma agrária na Amazônia. Petrópolis-RJ: Vozes, 1979.

MARTINS, José de Souza Martins. Expropriação e Violência: A questão Política no campo. $3^{\text {a }}$ Ed. São Paulo: Editora Hucitec, 1991.

MESQUITA, Helena Angélica de. Corumbiara: o massacre dos camponeses. Rondônia, 1995. Tese de Doutorado. FFLCH/USP, 2001.

PRYSTHON, Ângela. Histórias da teoria: os estudos culturais e as teorias pós-coloniais na América Latina. Revista do Programa de Pós-Graduação em Comunicação e Linguagens. Universidade Tuiuti do Paraná, v. 9, n. 1, 2010. 


\title{
A migração na visão da mídia impressa e seu papel na difusão de Rolim de Moura
}

\author{
Maria Aparecida da Silva (UNIR) \\ Odete Burgeile (UNIR)
}

\section{Introdução}

O desafio proposto foi discorrer sobre a migração na visão da mídia impressa e seu papel na difusão de Rolim de Moura, através da visão do Estado e a partir da vida dos migrantes. Para que houvesse esta discussão, foi necessário estabelecer o diálogo das fontes de mídias impressas como jornais e revistas, com autores como Ortiz (1991) que traz reflexões sobre os interesses do Estado brasileiro, Santos (2001) que desenvolve uma sistemática da abordagem sobre Rolim de Moura, e Martins (2009) que apresenta uma forma de ver o papel do capital e a forma como os migrantes se ajustam nesta fronteira.

Além da pesquisa histórico-bibliográfica proposta por Severino (2002), outros dois métodos foram utilizados na coleta de dados. O primeiro foi a Roda de Conversa (PERE PETIT $^{\mathbf{1}}$ ) e o segundo foi a aplicação de um questionário junto à rede de contatos. Eles foram recursos fundamentais para conhecer a história dos migrantes e suas experiências de vida ocorridas desde sua terra natal até chegar a Rolim de Moura - RO.

\section{As visões de progresso do estado para a região rolimourense.}

Ao fazer uma análise da sociedade rolimourense, buscou-se as causas que contribuíram para que Rolim de Moura deixasse de ser somente um projeto de extensão agrícola e se tornasse um grande celeiro madeireiro e agrícola atraindo para si interesses estratégicos no campo político e econômico do então Território Federal de Rondônia, que ao se tornar Estado em 1981, vê a necessidade de gerar receitas e quanto mais municípios, maior seria a arrecadação. Dados do Jornal A Tribuna (09/06/1983, s.p.) revelam que,

\footnotetext{
Rolim de Moura representa em meados de 1983, 50\% da carteira agrícola de Cacoal, que além das culturas de café, arroz, milho, feijão e mandioca, Rolim de Moura se constituí - se de uma importante região de reserva madeireira. Atualmente, o mogno e a cerejeira, encontrados na área, representam grande fonte divisas para Rondônia.
}

Isso justifica o interesse do Estado haja vista que esta atividade econômica foi a que mais gerou riquezas para o município permitindo dizer, também, que o lucro para Rolim de 
Moura foi uma realidade em um período de três (03) anos aproximadamente, já que politicamente pertencia a Cacoal. Fidélis Sobrinho (Entrevista à Revista Ideias \& Fatos em 25 de janeiro de 1998, p. 17) afirma que:

\begin{abstract}
No começo mesmo não tinha jeito de explorar a madeira. Não tinha estrada. Depois foi coisa de louco. Saiu muita madeira daqui. Muita gente ganhou dinheiro e muita gente deixou de ganhar. O pessoal fazia derrubada. Ai vinha um mais esperto e tirava as toras. Teve um cara de Cacoal que levou muita aroeira daqui. Ninguém se preocupava, ele vinha, tava derrubado e largado. Ele levou pra Cacoal [sic].
\end{abstract}

Neste caso, ao tornar-se município, geraria em termos econômicos e sociais, benefícios para o Estado. Diante dessa situação constata-se que Rolim de Moura tornar-se-ia um ponto de referência até mesmo na questão geográfica, pois estaria garantindo a ocupação e o controle do Vale do Guaporé.

Em consequência disso, nota-se a presença do Estado a partir de 1980 na região, quando este inicia a abertura de estradas ligando a BR 364 com a RO 479, bem como a instalação de uma balsa no Rio Ji-Paraná na passagem para Rolim de Moura, o que possibilita conforme informações do Observador Amazônico ${ }^{2}$ (Ano 3, fevereiro/março de 1980, s.p.):

Criação e a implantação da Vila Rolim de Moura com definição e topografia de ruas e avenidas e o distrito industrial, além da construção de 36 pontes de madeira, 01 escola com 05 salas, agência dos correios, CERON, TELERON, Delegacia de Polícia e um Hospital em Rolim de Moura, ainda distrito de Cacoal.

Esta estrutura viria minimizar problemas ocasionados pelas chuvas principalmente no que se refere à questão das estradas. Segundo noticiários do Jornal Alto Madeira (Janeiro de 1979, p. 5),

Devido às chuvas constantes, Comunidades ligadas a BR 364, como a sede do Projeto Rolim de Moura (Município de Cacoal em Rondônia) estão praticamente isoladas e que se não acontecerem dias seguidos de sol toda a área poderá sofrer violentamente com problemas de abastecimento básico.

No entanto, a ação do Estado só se fez presente na região quando Cacoal fez reivindicações ao então governador Jorge Teixeira para que fizesse a abertura e conservação das estradas vicinais, via BR 364 - RO 479; RO 010 - entre Pimenta Bueno e Rolim de Moura e RO 383 (antiga Linha 208) - ligando Cacoal a Rolim de Moura, pois ambas faziam e continuam estabelecendo comunicação terrestre entre estas cidades.

Além das pessoas que faziam as vias de acesso a Rolim de Moura a pé, outras enfrentavam os atoleiros empurrando carros, caminhões de tora e ônibus que mais tarde vieram fazer o trajeto entre as localidades já mencionadas. Os migrantes que chegam até o ano de 1984 tinham a chance de ser contemplados na seleção para a aquisição dos lotes agrícolas. Sobre o assunto, a Revista Momento (1984, p. 36) traz como encarte em uma de suas edições,

Em 1984 o presidente Figueiredo entregou 3.700 títulos aos sem-terra, beneficiando agricultores assentados em diversos projetos nos municípios que resultaram da Colonização iniciada em 1970 pelo INCRA, entre eles está Rolim de Moura. A partir deste período o acesso à terra foi reduzido drasticamente.

\footnotetext{
${ }^{2}$ A Revista da Amazônia - Circulação Internacional.
} 
O processo se recria 20 anos após o início da colonização agrícola, em Rondônia, nos mesmos moldes em que o agricultor é forçado a desmatar, caso contrário poderia perder a posse definitiva da terra. Isso leva a crer que, mesmo com todo um aparato e estrutura legal que pudesse contribuir para uma ocupação mais humanizada e equilibrada ambientalmente na região, o próprio estado cria obstáculos para que isso ocorra. Surge a contradição dez anos depois, quando o agricultor precisa manter-se na área por meio da abertura da floresta e este é barrado de acordo com as leis ambientais.

Estes fatos permitem compreender os interesses do Estado no desenvolvimento da região de Rolim de Moura e considerar as pretensões em relação à Amazônia. Neste caso, também para Rondônia, uma vez que, mesmo não se sentindo parte da Amazônia, os migrantes em foco estão inseridos neste espaço geográfico. Tendo este aspecto bem esclarecido, o governo federal pleiteia diminuir a tensão dos grandes centros urbanos da época e ampliar os investimentos na indústria e mecanização agrícola nas regiões Sul e Sudeste do Brasil. Renato Ortiz (1991, p. 115) destaca que a ação do governo federal se desdobra, justamente porque,

Trata-se de um Estado que é percebido como centro nevrálgico de todas as atividades sociais relevantes em termos políticos, daí uma preocupação constante com a questão da "integração nacional". Uma vez que a sociedade é formada por partes diferenciadas, é necessário pensar uma instância que integre, a partir do centro, a diversidade social.

O Estado brasileiro utiliza-se da mídia divulgando o slogan da "integração nacional" para fazer propaganda das terras ao Norte do Brasil, veiculando a ideia de que aqui os problemas dos agricultores seriam resolvidos. Mas, o que Pessoa (1988, p. 65) apresenta é que,

O tempo passando, o sul do Brasil superlotando-se e a esperança, então, estava contida, ainda, nesta parte norte. E, quando em 1975 o INCRA fazia entrega dos primeiros lotes de terras a agricultores excedentes de Cacoal, estes fundaram Rolim de Moura.

Tendo o Sul e o Sudeste do Brasil superlotado e graves conflitos sociais, o governo precisava urgentemente solucionar os problemas demográficos e sociais. A alternativa seria então divulgar por meio dos MCS - Meios de Comunicação Social - a existência destas terras e estimular a vinda de quem não tinha nada a perder em meio ao caos já estruturado.

Outro motivo que trouxe um elevado número de migrantes a Rolim de Moura foi o prejuízo que muitos tinham na agricultura com as geadas, principalmente nos Estados do Paraná, Santa Catarina e Rio Grande do Sul. Ouvindo as histórias que chegavam de Rondônia, apresentando-a como uma terra promissora e favorável para quem desejava uma vida melhor, muitos resolveram trazer suas famílias sem pensar em um possível retorno.

Entretanto, Ortiz (1991, p. 118) afirma que o objetivo do governo e dos grandes empreendedores, com o poder midiático em suas mãos, era o desenvolvimento do mercado, isto é, os planos de desenvolvimento vinham imbuídos com seu sentido social e econômico. Assim, o poder da propaganda trouxe para esta região milhares de migrantes que cumpriam o dever do próprio Estado no sentido de ocupar e garantir o 'progresso'.

Diante destas promessas, milhares de famílias vieram tentar a sorte, justamente porque recebiam informações sobre de uma região em expansão. Estas notícias eram repassadas pelos migrantes que já estavam morando em definitivo e trabalhando no Projeto Agrícola Rolim de Moura e, assim, aos poucos constituiu-se "a produção de significado de identidade" (CASTELLS, 1999, p. 80). 


\section{Rolim de Moura: espaço de fenômenos culturais e socioeconômicos}

Rolim de Moura era "na realidade era inicialmente um projeto de assentamento agrícola, e não urbano" [sic], afirma Francisco Ferreira Moreira (Entrevista à Revista Ideias e Fatos, Ano I, nº 2, dezembro de 1998, p.17). Ele nasceu em Aurora, Ceará, veio para Rondônia, passando por Ouro Preto D'Oeste, Cacoal e por último Rolim de Moura, do qual foi o primeiro executor e administrador entre 1978/1979.

No entanto, a falta de terra permitiu que dezenas de famílias se estabelecessem nas proximidades do Rio Anta Atirada e do escritório do INCRA à espera de terras. Enquanto isso não ocorria, surgiram as primeiras casas, pequenos pontos de comércio, a Igreja, a escola, e a partir de então, o núcleo urbano de Rolim de Moura.

A ideia de que o Estado esteve presente desde o início é uma farsa. É de conhecimento geral da comunidade rolimourense que foram os migrantes que abriram as estradas e construíram pontes, escolas, igrejas, entre outros símbolos que transformaram uma área que deveria ser essencialmente agrícola justamente por ser um assentamento agrícola e não urbano, em uma cidade que indicava prosperidade, conforme afirma o executor do INCRA na época, Sr. Francisco Ferreira Moreira (Entrevista à Revista Ideias e Fatos, Ano I, no 2, dezembro de 1998, p.17)

\footnotetext{
Na realidade, foi o povo que criou Rolim de Moura. No projeto do INCRA era só distribuição de lotes rurais. $\mathrm{O}$ povo foi chegando, abrindo as picadas até onde deveria ser o lote. Depois é que o INCRA fazia a demarcação topográfica. E esse processo aconteceu tanto na área rural como urbana. Quase não havia ação do governo. A abertura de Rolim de Moura se deu pela ação do povo. O governo não oferecia nenhuma estrutura. As pessoas iam na frente e o governo vinha atrás [sic].
}

Outros aspectos apontados pelos entrevistados indicam que a cidade de Rolim de Moura origina-se de um agrupamento de pessoas nas proximidades do Rio Anta Atirada, à espera de lotes agrícolas a serem distribuídos pelo órgão competente. O povo constrói a igreja católica e a primeira escola dentro do vilarejo, ambas feitas de taipa e cobertas de tabuinhas. Em entrevista à Revista Ideias \& Fatos, o Sr. Francisco Ferreira Moreira (Entrevista à Revista Ideias e Fatos Ano I no 2, dezembro de 1998, p.17) afirma que a primeira escola, a Pereira da Silva e a Igreja católica surgiram em função da necessidade que os moradores tinham destas entidades. De acordo com os relatos orais, eles mesmos as construíram.

O solo só era bom quando a floresta fornecia, através das folhas, adubo suficiente, isto é, fortalecia superficialmente e o protegia. Quem confirma esta situação é a Sra. Olaídes Amaral da Silva (Revista Ideias \& Fatos, 25/03/1999, p.17): "Tinha propaganda do governo. O governo incentivava, dizendo que a terra era fértil, que produzia bem. Tinha propaganda que o INCRA estava dando terra, que tinha financiamento. Mas chegava aqui e descobria que não tinha nada" [sic].

Diante de tal realidade, centenas de famílias que não tinham condições em investir na terra, buscam outras formas de sobrevivência, aqui ou em alguma fronteira agrícola, seja em Rondônia ou no Mato Grosso, Acre e Amazonas, por exemplo, sempre almejando terra produtiva que pudesse dar retorno financeiro. Sr. Geraldino R. Jorge (Revista Ideias \& Fatos, maio de 1999, p.15) lembra que: 
Muita gente vendeu. Acho que só uns $10 \%$ permaneceu no terreno. Os outros $90 \%$ vendeu. Alguns, por causa das dificuldades, outros por que a política econômica do país muda todo dia. E ai os juros e as dificuldades obrigam o agricultor a vender o sítio. Dentro de pouco tempo já estava falido $[s i c]$.

É visível que a propaganda midiática por meio dos jornais já mencionados e os relatos dos migrantes na Revista Ideias \& fatos se contradizem uma vez que as promessas não foram cumpridas e as pessoas que vieram para as terras rolimourenses sentiram-se enganadas, pois as terras eram fracas e, além do mais, não receberam incentivos agrícolas para que se mantivessem na terra.

Entretanto, tal aspecto não inibiu que houvesse uma inter-relação entre fenômenos culturais e socioeconômicos que, por meio do impulso social, gera a transformação do mundo via projeto intelectual. A cultura é, portanto, o resultado da intervenção da sociedade contrapondo-se as relações reais e materiais.

Neste caso, a cultura é chamada a desempenhar um novo papel social: de apaziguar e organizar a anarquia do mundo real dos conflitos e disputas sociais que segundo Freud (1974, p. 17-24) seriam apaziguadas pela civilização e a religião.

A religião em si teria, de acordo com Bourdieu (2007, p. 71) o poder da "unificação dos universos separados", os diversos interesses envolvidos na busca pela posse da terra e os conflitos atribuídos a esta questão, bem como "a manutenção da ordem política" local. Estrategicamente ou indiretamente apaziguar as diversas situações seria a função da esfera religiosa.

A vinda dos migrantes para Rolim de Moura propiciou a consolidação da História das pessoas envolvidas na construção deste ambiente permitindo que lancemos o olhar sobre as centenas e milhares de famílias que cruzaram o Brasil e edificaram suas vidas, implantando nesta vasta região padrões econômicos, políticos, culturais e de sociedade civil organizada muito similar aos quais como cidadãos onde nasceram ou tiveram a oportunidade mesmo forçada de fixar residência, seja em um longo ou curto período.

Rolim de Moura, em sua formação cultural, possui o que denominamos de diversidade cultural como base central, considerando que localmente ou no sul e centro - sul do Estado de Rondônia foi composto por migrantes que vieram de todas as regiões do Brasil. Cada pessoa trouxe consigo uma visão de mundo seja ela social-religiosa e outros costumes, tais como gostos culinários, danças típicas e práticas agropastoris, conforme suas tradições familiares, ou seja, "a diversidade cultural é um fator de enriquecimento" (ALVES \& ALEIXO, 2011, p. 130135) e se define como "intercâmbio entre diferentes culturas" (MOURA, 2010, p. 321).

Em terras rolimourenses as experiências deste intercâmbio cultural, do 'encontro' e do 'desencontro' foram frequentes, justamente porque a diversidade cultural permeou a vida de quem aqui está neste período de aproximadamente quarenta (40) anos. Isso fica esclarecido quando Vilhena \& Siqueira (2001, p. 220) mencionam que

No âmbito histórico-cultural, o município de Rolim de Moura também se sobressai com expressivo potencial em decorrência, sobretudo do grande fluxo migratório - fator determinante da diversidade de manifestações culturais e folclóricas, presente nas festas tradicionais que integram o calendário de eventos cívicos, culturais e esportivos do município, a saber: os festejos juninos, o aniversário do município, a exposição agropecuária, os campeonatos e torneios esportivos de abrangência nacional, estadual, regional e municipal sediados no município. 
Neste caso, os autores acima citados propõem discutir os aspectos culturais que regem a história do município de Rolim de Moura é fundamental, pois, ao rememorar as datas comemorativas, no caso do carnaval que acontece desde a chegada dos primeiros migrantes, mais especificamente desde 1979, permite uma visualização simbólica e imaginária de que aqui também é Brasil.

A percepção das diferenças culturais foi observada pelos participantes da atividade denominada Roda de Conversa, cujos dados relacionados as suas ocupações dos participantes. Dentre os participantes, a menção aqui se refere a Antônio da Nóbrega (Roda de Conversa, 10/01/2010) funcionário aposentado da SUCAM- Superintendência de Campanhas de Saúde Pública. Ele foi responsável por fazer visitas às casas, onde passava o veneno para eliminar os focos existentes de mosquitos transmissores de malária. Ele prestou serviço nos anos finais da década de 1970 e nos primeiros anos da década 1980 à população de Rolim de Moura, que no período pertencia ao Município de Cacoal.

Em suas visitas aos agricultores era possível perceber o modo de falar e linguajares que se diferem entre os descendentes de alemães que vieram do Espírito Santo, em relação aos migrantes que saíram de Santa Catarina e do Paraná, por exemplo, pois, cada grupo de descendentes de alemães tinha suas peculiaridades culturais.

A percepção das diferenças culturais - no jeito de falar: passar banha na 'xana', ou seja, passar banha na gata para não morrer pela contaminação do veneno e ainda a expressão 'o cuzin' está pronto, isto é, o cozido está pronto para o almoço, entre outros aspectos vivenciados entre os descendentes de alemães, que vieram do Espírito Santo em relação aos migrantes que saíram de Santa Catarina e do Paraná.

Considerando as características expressas no modo de falar, nas gírias e linguajares estes elementos vão incorporar à língua que, de acordo com Giommi (2011, p. 281), "realmente cria o mundo no qual vivemos".

\section{As contribuições dos migrantes na constituição do multiculturalismo local}

Rolim de Moura, assim como o Estado de Rondônia compõem-se culturalmente a partir da ideia de Bhabha (1998, p. 20) da "necessidade de compreender a diferença cultural" e se adequando, pois, é justamente aqui que a junção do híbrido, sob a visão de Alves e Aleixo (2011, p. 146) e do sincrético que faz esse povo diferente e singular. E a língua é o resultado de tudo e de todos que para cá vieram.

De modo geral, a influência da língua está presente nas diversas atividades culturais existentes e expressas exatamente de acordo com os moldes em que os migrantes desenvolviam em suas terras natais. Temos como exemplo disso, as festas juninas, aqui, às vezes julinas, e, nesse caso, algumas coisas nos lembram do Sul, como o quentão, a fogueira. Na culinária é muito comum aqui a moqueca de peixe capixaba, a bacalhoada, o churrasco, o chimarrão e o tradicional arroz, feijão, bife e ovo. Há muitos nordestinos, 'os nortistas' e sulistas. Assim sendo, as adequações da culinária são necessárias diante da realidade que está em fase de constituição.

As festas nas comunidades católicas na cidade e nas linhas são consideradas um marco em pleno século XXI. Enfim, houve uma adequação dos costumes e as diferenças 
culturais entre a terra natal dos migrantes e Rolim de Moura são poucas, em função da reprodução das tradições feita na nova terra.

As adequações acima apontadas demonstram que os migrantes, de certa forma, conviveram e tentaram construir uma vida em comum, embora fossem culturalmente heterogêneos (HALL, 2003, p. 52-76). Isso constituiu um hibridismo cultural, já que aqui as pessoas tiveram que rever, isto é, repensar seus padrões culturais.

Para Escosteguy ${ }^{3}$, estes aspectos fazem parte das formas e práticas culturais integradas a um contexto intelectual, político, social e histórico específico e condicionado. Para Santos $(2009$, p. 8), há uma realidade cultural, pois,

\section{Cada realidade cultural tem sua lógica interna, a qual devemos procurar conhecer para que façam sentido as suas práticas, costumes, concepções e as transformações pelas quais estas passam. É preciso relacionar a variedade de procedimentos culturais com os contextos em que são produzidos.}

Seja nos aspectos culturais ou no campo sócio-político e econômico, o progresso fantástico da 'capital da madeira' foi consequência do esforço consciente e arrojado da iniciativa popular, ou seja, a coragem dos migrantes que, de fato, acreditaram e apostaram na então Vila de Rolim de Moura, transformando-a em uma cidade que chamou atenção de muita gente e recebeu o título 'fenômeno amazônico'. O grau de confiabilidade na cidade foi um dos elementos que propiciaram seu desenvolvimento.

É incontestável o desenvolvimento da cidade em diversos aspectos, tornando-a referencial para o Estado. Quando da sua emancipação política, o então Governador Jorge Teixeira de Oliveira fez a seguinte afirmação, conforme nos aponta o Jornal A Tribuna (06/08/1983, s.p.) "estava fazendo justiça a capacidade de trabalho e a fé desse povo que soube compreender que somente com trabalho, dignidade e honestidade, Rondônia chegará ao seu grande destino".

Outro detalhe importante relativo à Rolim de Moura é que desde sua emancipação assumiu o posto de capital da 'zona da mata'. Sendo, portanto, o centro comercial da região, mesmo que o ciclo da madeira tenha deixado de ser a principal fonte da economia local. Isso aconteceu porque a cidade continuou sendo receptora da produção dos municípios vizinhos, conforme afirma Santos (2001, p. 141),

\footnotetext{
O setor comercial de Rolim, apoiado predominantemente na atividade agrária da região tem apresentado uma notável evolução, tornando-se nódulo da área de influência do município, isto é, transformou-se em entreposto da região ao receptar a produção de cereais circunvizinha, com a intensa atividade do ramo de intermediação agrícola, além de seu centro de distribuição de mercadoria.
}

Assim sendo, o referido município tornou-se se um centro comercial para população da região, influenciando economicamente, sendo vital para o progresso do seu entorno, pois em Rolim de Moura, conforme afirma Bassegio \& Perdigão (1992, p. 97), “O migrante aqui chega e não encontra orientação, fica amontoado em estações rodoviárias ou em galpões de igrejas, como acontece na paróquia de Rolim de Moura".

\footnotetext{
${ }^{3}$ ESCOSTEGUY, Ana Carolina. Os $\quad$ Estudos Culturais. $\quad$ Disponível em <Http://www.pucrs.br/famecos/pos/cartografias/artigos/estudos_culturais_ana.pd>. Acesso em 22 de Janeiro de 2015 .
} 
De fato, estes migrantes ficavam à espera de trabalho no barracão da Paróquia Nossa Senhora Aparecida - Igreja Matriz. Boa parte foi trabalhar de 'meeiros' nos sítios localizados nas linhas vicinais, onde recebiam pelo trabalho, parte da colheita do café e da lavoura branca.

Minc (1985, p. 44-45 apud OLIVEIRA, 1997, p. 100) destaca ainda,

Estas relações de agregados e meeiros são muito importantes por que são base do trabalho e das diferenças que se estabeleceram. O meeiro se instala com toda a família no lote de um colono, enquanto aguarda receber lote, ou que o lote recebido se torne acessível.

O meeiro, após acumular um determinado valor, consegue comprar um pedaço de terra ou adquiri-lo junto aos projetos de assentamentos nas localidades já mencionadas. Entretanto, alguns deles adquiriram um pequeno lote ou chácara no local onde moravam, ou seja, na linha onde tinham residência fixa. Isso se justifica pelo fato de que a busca pela terra em outros municípios levá-los-iam a encarar experiências que, de modo geral, já haviam vivenciado, tais como a falta de estrada para o escoamento da produção agrícola, escola, atendimento médico (postos de saúde no mínimo), para "sanar" ou pelo menos minimizar o grande vilão que atingia a muitos: a malária, entre outras situações que poderiam causar sérios problemas econômicos e sociais.

Algo que ainda sustenta o agricultor que permaneceu no campo, na terra, é o companheirismo, 'o compadrio,' tanto enfatizado por José de Souza Martins (2009, p. 150), pois, há uma teia de relações de parentesco e de compadrio se encarrega de difundir as informações sobre a localização de novas terras que ainda podem ser ocupadas.

Como consequência destas redes, tornam-se apoio mútuo fazendo surgir as associações rurais que garantem essa proximidade dos colonos. Essas entidades são ligadas e assistidas pelo STR - Sindicato dos Trabalhadores Rurais de Rolim de Moura - Rondônia. Santos (2001, p. 136-138) resgata o sentido das associações para Rolim de Moura como inspiradoras do processo de participação política no campo.

Na prática, o que vem dificultando a vida no campo é a desvalorização dos produtos agrícolas, em que o plantio fora substituído pela produção leite e gado de corte com a instalação de frigoríficos. Grande parte dos agricultores desestimulados não desenvolve a produção das culturas permanentes, o café e as perenes - arroz, feijão e milho, pois o preço pago a cada saca é irrisório. No entanto, é muito característico de Rolim de Moura a produção e cultivo de hortifrutigranjeiros por pequenos sitiantes e chacareiros, que mantém as feiras livres e o comércio do município.

\section{Considerações finais}

Em vista dos argumentos apresentados, discorrer sobre "A migração na visão da mídia impressa e seu papel na difusão de Rolim de Moura na visão do Estado e a partir da vida dos migrantes" possibilitou averiguar que os jornais e algumas revistas analisados das décadas de 1980 serviram como instrumentos ideológicos do Estado, uma vez que se ocuparam em fazer a propaganda do Distrito de Rolim de Moura como região promissora no campo econômico para Rondônia.

Ao observar as narrativas dos migrantes nos exemplares da Revista Ideias \& Fatos (1998-2000), nota-se as contradições existentes, já que estes sujeitos vieram guiados pelas 
propagandas governamentais e se decepcionaram com a ausência total do Estado nesta região inóspita onde tiveram que fazer tudo, desde a derrubada da floresta e abertura das estradas, às construções de escolas e igrejas, principais representações identitárias da população.

Entende-se que o Estado brasileiro utilizou-se das estratégias midiáticas para aliviar os conflitos e urbanos do Centro-Sul do Brasil e esquivou-se ao não oferecer estrutura básica para o contingente migracional que serviu de mão de obra na abertura destas terras.

\section{Referências}

Alto Madeira. Jorge Teixeira já estuda soluções para Rondônia. Porto Velho: Janeiro de 1979.

ALVES, Érica F. \& ALEIXO, Regina L. Racismo e abertura do multiculturalismo em Small Island (2004) e Fruit of the Lemon (1999) de Andrea Levy. IN: BONNICI, Thomas (Org). Multiculturalismo e diferença: Narrativas do sujeito na literatura negra britânica e em outras literaturas. Maringá - PR: EDUEM, 2011, 359p.

A Tribuna. Messias confirma a emancipação de Rolim de Moura e Cerejeiras. Porto Velho: 09 Junho de 1983.

Governador Teixeira decreta emancipação de Rolim de Moura e Cerejeiras. Porto Velho: 06 de Agosto de 1983.

BHABHA, Homi K. O local da Cultura. Tradução de Myriam Ávila et al. Belo Horizonte: Editora EFMG, 1998.

BOURDIEU, Pierre. O poder político e poder religioso In: A Economia das trocas simbólicas. Introdução, organização e seleção de Sérgio Miceli. São Paulo: Perspectiva, 2007. (Coleção Estudos)

CASTELLS, Manuel. O poder da identidade. v. II - Tradução: Klauss B. Gehardt. São Paulo: Paz e Terra, 1999.

ESCOSTEGUY, Ana C. Os Estudos Culturais. Disponível em <https: //www.pucrs.br/famecos/pos/cartografias/.../estudos_culturais_ana.pdf. $>$ Acesso em $15 \mathrm{de}$ Fevereiro de 2015.

FREUD, Sigmund. O futuro de uma ilusão, o mal-estar na civilização e outros trabalhos. Rio de Janeiro: Imago Editora, 1974.

GIOMMI, Francesco. Diáspora, Hibridismo e memória na ficção "Igbo Globlal" de Chris Abani. IN: BONNICI, Thomas (Org). Multiculturalismo e diferença: Narrativas do sujeito na literatura negra britânica e em outras literaturas. Maringá - PR: EDUEM, 2011, 359p.

HALL, Stuart. Questão Multicultural In: DA DIÁSPORA: Identidades e Mediações

Culturais. Tradução de Adelaine La Guardia (et all). Belo Horizonte: Editora UFMG; Brasília Representação da UNESCO no Brasil, 2003. 
JORGE, Geraldino R. Entrevista à Galeria dos Pioneiros da Revista Ideias \& Fatos. Revista Mensal de Reflexão. Ano I nº 7, Maio de 1999.

MARTINS, José de Souza. FRONTEIRA - A Degradação do Outro nos Confins do Humano. São Paulo: Ed. Contexto, 2009.

MOREIRA, Francisco F. Entrevista à Galeria dos Pioneiros da Revista Ideias \& Fatos. Revista Mensal de Reflexão. Ano I nº 2, Dezembro de 1998.

MOURA, Milton. Cultura e Diversidade: Considerações sobre a multiplicidade das manifestações. Revista Antíteses, vol.3, n. 5, jan. - jun. de 2010, pp. 321-346. Disponível em <http://www.uel.br/revistas/uel/index.php/antíteses> Acesso em 15 de Fevereiro de 2015.

OLIVEIRA, Ariovaldo Umbelino de. AMAZÔNIA: Monopólio, Expropriação e Conflitos. $5^{\text {a }}$ ed. - São Paulo: Papirus Editora, 1997.

ORTIZ, Renato José P. A moderna tradição brasileira. Cultura brasileira e indústria cultural. $3^{\mathrm{a}}$ ed. São Paulo, Brasiliense, 1991.

PESSOA, Maria do Socorro. ROLIM DE MOURA - Um ponto vista. CEGRAF, Brasília,1988.

PETIT, Pere. REFLEXÕES SOBRE AS “RODAS DE CONVERSA” COMO FONTE PARA O ESTUDO DOS MOVIMENTOS SOCIAIS. Disponível em $<$ http://www.encontro2012.historiaoral.org.br > Acesso em 06 de Agosto de 2014.

REVISTA MOMENTO. A Revista da Amazônia. Colonização - Figueiredo entregou 3.700 títulos aos sem terra. Ed. Rota Oeste, Ano I nº 02 Setembro e Outubro de 1984.

SANTOS, Carlos. A Fronteira do Guaporé. Porto Velho: EDUFRO, 2001.

SANTOS, José Luiz. O que é Cultura? São Paulo: Editora Brasiliense, 2009.

SEVERINO, Antônio Joaquim. Metodologia do Trabalho Científico. São Paulo: Editora Cortez, 2002.

SILVA, Olaídes Amaral Entrevista à Galeria dos Pioneiros da Revista Ideias \& Fatos. Revista Mensal de Reflexão. Ano I nº 5, Março de 1999.

SOBRINHO, Fidélis. Entrevista à Galeria dos Pioneiros da Revista Ideias \& Fatos. Revista Mensal de Reflexão. Ano I nº 3, Janeiro de 1998.

OBSERVADOR AMAZÔNICO. A Revista da Amazônia. Circulação Internacional. A Topografia da área urbana de Rolim de Moura. Ano 3 Março de 1980.

VILHENA, João \& SIQUEIRA, José P. OS PIONEIROS. Ji-Paraná: Ed. Ji - Paraná Agora, 2001. 


\title{
O discurso sobre o Brasil na mídia e a identidade do brasileiro
}

\author{
Liubov Tarasova (UNIR) \\ Odete Burgeile (UNIR) \\ Élcio Aloisio Fragoso (UNIR)
}

\section{Introdução}

O desenvolvimento dos meios de comunicação de massas, ou mass mídia, resultou da necessidade de veiculação rápida e eficaz da informação que se destina a um elevado número de sujeitos. Consciente ou inconscientemente, os media, que inclui jornais, TV, internet, radio entre outros, tornaram-se parte importante da vida quotidiana dos sujeitos, levando se em conta tanto a perspectiva individual como a perspectiva social. Pode-se então supor que os mass midia são efetivamente um meio de controle e de construção da sociedade. Perante o poder da informação que chega aos indivíduos através da mass midia os sujeitos encontram-se relativamente indefesos contra essa influência. Os sujeitos menos preparados podem ser até mesmo manipulados pelo discurso recorrente e sempre ideológico da mass mídia, pois "o sujeito discursivo funciona pelo inconsciente e pela ideologia" (ORLANDI, 2013, p. 20).

Como diz Orlandi (ORLANDI, 2013, p.17), o discurso é o lugar em que se pode observar a relação entre língua e ideologia, compreendendo-se como a língua produz sentidos para os sujeitos. Podemos considerar que a materialidade da ideologia é o discurso, e a materialidade do discurso é a língua. Assim, articulam-se língua e ideologia com o discurso.

Mass mídia produz o discurso e o coloca em circulação na sociedade brasileira, agindo assim de forma ativa sobre a imagem da realidade e de se mesmo. Então, podemos supor que a identidade é construída no discurso no processo da interpelação ideológica do sujeito. Neste contexto, insere-se a problemática da constituição das identidades na sociedade brasileira, como a mass mídia internacional pode influenciar na forma como o brasileiro associa o seu país e seu povo. Investigar o discurso a partir dessa perspectiva seria observar como os participantes estão sendo envolvidos na construção do significado, criando sentidos e agindo socialmente, desse modo, construindo a sua realidade.

\section{Levantamento teórico}

No momento do surgimento da Análise do Discurso em 1969, ainda não se tratava de uma definição direta da identidade discursiva. O sujeito aparece a partir de representações imaginárias dos lugares sociais que os interlocutores ocupam nas situações. Esse imaginário inclui, também, o "ponto de vista dos sujeitos" quanto ao contexto do discurso (TASSO, 2005, p. 1-2). Pecheux (1997, p. 61-105) enfatiza que o sentido é algo produzido em meio das relações de força específicas a dada situação. Pêcheux foi contrário a qualquer consideração de um sujeito psicológico que esteja livre de determinações e, também, contrário à concepção da língua 
abstraída da história. O autor afirma, que o "discurso é sempre pronunciado a partir de condições de produção dadas". (Pêcheux, 1997", p.77). Para ele, o discurso não seria uma parole ou extensão da frase e o sujeito não seria "fonte" individual de seu dizer, e assim os sentidos seriam produzidos no processo sócio-histórico determinado.

Considerando as condições de produção, a análise do discurso pensa a situação de interioridade/exterioridade do discurso em relação a seu contexto sócio-histórico. Assim, o sujeito seria determinado na estrutura de uma formação social caracterizada por meio do modo de produção que a domina e por um estado determinado pela relação de classes que a compõe. Segundo Orlandi, para Pêcheux foi importante o fato de que "como nossa sociedade é dividida, há uma divisão nos sentidos, eles não significam a mesma coisa para todos, mas, sim, na diferença"1.

Por fim, sob essa noção de condições de produção, pode-se afirmar que o processo discursivo remete conjuntamente a um exterior específico.

(...) um exterior especifico: o aparelho hegemônico corresponde às posições ideológicas de classe e à base linguística constitutiva da reprodução/transformação de uma formação social; a um interior específico: os mecanismos reais/imaginários que mobilizam, por refração, o referente ideológico no interior do complexo dominado por formações sociais/discursivas. (GULHAUMOU, 2008, p. 62)

Assim, a identidade discursiva estaria projetada no lugar social ocupado por um sujeito quando anuncia. A interpelação ideológica converte sujeitos em sujeitos ideológicos, que se pronunciam e assim produzem sentidos conforme o lugar que são chamados a ocupar em dado aparelho ideológico ou uma relação de classes. (TASSO, 2005, p. 2)

No livro "Papel da Memória", Orlandi raciocina sobre discursos construídos durante período da resistência política no Brasil de 1968:

Eu vi, em meu silencio, muitos de meus colegas com suas fotos afichadas como perigosos guerrilheiros em pilares da rodoviária de São Paulo toda vez que ia tomar ônibus. Eram lidos, vistos, pensados como perigosos terroristas. Por onde passam os sentidos do terrorismo? Por onde passam os sentidos da resistência política de 68? Os sentidos de liberdade? (Orlandi, 2010, p. 66)

Outro exemplo da criação dos sentidos discursivos diferentes a partir do mesmo enunciado pode ser a noção de "liberdade", que, segundo Orlandi, "sem determinações concretas, agora generalizada, pode ser reivindicada, individualizando-se, até pelos neo-nazistas que, em nome dela, exigem o direito de usar a suástica em suas roupas opressivas". (ORLANDI, 1999, p. 64)

Para que uma palavra faça sentido é preciso que ela já tenha sentido. Essa impressão do significar deriva do interdiscurso - o domínio da memória discursiva, aquele que sustenta o dizer na estratificação de formulações já feitas, mas "esquecidas", e que vão construindo uma história dos sentidos. Toda fala resulta assim de um efeito de sustentação no já dito [...] (ORLANDI, 1996, p. 71)

\footnotetext{
1 "Eni Orlandi fala sobre análise do discurso e linguagem em entrevista", 28/02/2013, por Tatiana Fávaro, São Paulo. Fonte: http://redeglobo.globo.com/globouniversidade/noticia/2012/11/eni-orlandi-fala-sobre-analise-dodiscurso-e-linguagem-em-entrevista.html último acesso 02 de outubro de 2015.
} 
A Lingüística constitui-se pela afirmação da não transparência da linguagem: ela tem seu próprio objeto, a língua, e esta tem sua ordem própria. Esta afirmação é fundamental para a Análise do discurso, que procura mostrar que a relação linguagem/pensamento/mundo não é unívoca, não é uma relação direta que se faz termo a termo, isto é, não se passa diretamente de um a outro. (ORLANDI, 2007, p. 19)

Sendo o objeto do estudo, o discurso pode ser compreendido na busca dos sentidos, tendo a língua como materialidade não transparente, e que está sempre em movimento, não como um sistema estático e fechado em si mesmo. Segundo essa linhagem, a língua é o lugar da imprecisão, que admite contradições e deslizamentos.

Orlandi (2007. p. 30) refere-se sobre a exterioridade da língua e do sujeito discursivo, falando sobre "[...] efeitos de sentidos que são produzidos em condições determinadas e que estão de alguma forma presentes no modo como se diz", ou seja, como sentido ou sentidos em jogo dentro de um quadro político datado sócio-historicamente. Esse importante pressuposto nos ajuda para analisar e buscar compreender o modo como o discurso da mass mídia sobre o Brasil pode ter efeito sobre construção da identidade do brasileiro.

M. Pêcheux (1975, apud ORLANDI E. P., 2013, p. 17) diz que "não há discurso sem sujeito e não há sujeito sem ideologia: o indivíduo é interpelado em sujeito pela ideologia e é assim que a língua faz sentido". Então, todo discurso seria ideológico, mesmo parecendo ser neutro.

Segundo Orlandi (2013, p.17), o discurso é a materialidade específica da ideologia, e a língua é a materialidade específica do discurso. Pode-se deduzir que os sentidos produzidos dentro do discurso são sempre ideológicos. Diante de qualquer informação, o homem é levado a interpretar, a buscar o sentido. Ora, não há sentido sem interpretação, portanto, sem ideologia. "Assim considerada, a ideologia não é ocultação, mas função da relação necessária entre linguagem e mundo" (ORLANDI, 1999, p. 47).

Assim, para a Análise de Discurso, segundo Orlandi (2013):

a. A língua tem sua ordem própria, mas só é relativamente autônoma;

b. A história tem seu real afetado pelo simbólico (os fatos reclamam sentidos);

c. O sujeito de linguagem é descentrado pois é afetado pelo real da língua e também pelo real da história, não tendo controle sobre o modo como elas o afetam, assim, o sujeito discursivo funciona pelo inconsciente e pela ideologia.

Para analisar o sentido do discurso, tem-se que aceitar que não existe sentido "em si”, mas que o sentido é sempre construído "em relação a", segundo (Canguilhen, 1980, apud ORLANDI, 2013, p. 25).

A Análise do Discurso reúne três regiões de conhecimento para trabalhar o sentido: a teoria da sintaxe e da enunciação, a teoria da ideologia e a teoria da determinação histórica dos processos de significação, isto é discurso. (ORLANDI, 2013, p. 25). Também, segundo Orlandi (2001, p. 31), linguagem e história são fundamentais para Análise do Discurso a relação de sujeito.

É importante notar, que para Análise do Discurso não há uma verdade oculta atrás do texto, não se procura um sentido verdadeiro através de uma chave de interpretação. A interpretação é o sentido pensando-se o co-texto e o contexto imediato. (ORLANDI, 2013, p. 26). Então, para pessoas em contextos diferentes a interpretação do sentido pode resultar em construção de sentidos diferentes e até de sentidos opostos, assim como reações materializadas. 
Pode-se chegar à conclusão de que o poder do discurso sobre a sociedade seria significativo e por isso quem produz o discurso, quem põe o discurso predominante na sociedade, quem leva a sociedade a criar os sentidos desejáveis criando os contextos mentais necessários para isso, tem um instrumento forte sobre as materialidades do discurso, ações e movimentos da sociedade.

\begin{abstract}
The conscious and intelligent manipulation of the organized habits and opinions of the masses is an important element in democratic society. Those who manipulate this unseen mechanism of society constitute an invisible government, which is the true ruling power of our country.

A manipulação consciente e inteligente dos hábitos organizados e opiniões das massas é um elemento importante na sociedade democrática. Aqueles que manipulam esse mecanismo oculto da sociedade constituem um governo invisível, que é o verdadeiro poder do nosso país. (BERNAYS, 1928, tradução livre )
\end{abstract}

Como já mencionado, as companhias de mass mídia fornecem instrumentos poderosos para criar os contextos, relembrar para sociedade as memórias parcialmente esquecidas e assim acordar os sentidos já modificados e deslocados. Segundo Orlandi, todo dizer se encontra na confluência dos dois eixos: o da memória (constituição) e o da atualidade (formulação). (Orlandi, 2013, p. 33). Pêcheux diz que:

(...) as diversas formações resultam, elas mesmas, de processos discursivos anteriores (provenientes de outras condições de produção) que deixaram de funcionar mas que deram nascimento a "tomadas de posição" implícitas que asseguraram a possibilidade do processo discursivo em foco. (PÊCHEUX, 2001a, p.85)

Segundo Pêcheux (PECHEUX, 1999, p. 52), "a memória discursiva seria aquilo que, face a um texto que surge como acontecimento a ler, vem restabelecer os "implícitos" (quer dizer, mais tecnicamente, os pré-construídos, elementos citados e relatados, discursostransversos, etc.) ". A memória, quando utilizada na propaganda, não reflete uma verdade histórica, não pode servir como um indicador de alguma verdade, pois "uma memória não poderia ser concebida como uma esfera plena, cujas bordas seriam transcendentais históricos e cujo conteúdo seria um sentido homogêneo, acumulado ao modo de um reservatório: é necessariamente um espaço móvel de divisões, de disjunções, de deslocamentos e de retomadas, de conflitos de regularização", conforme Pêcheux (1999, p. 56).

Assim, pode-se assumir, que a memória qualquer que seja, evocada e repetida no conteúdo dos noticiários tem por seu objetivo agilizar algum discurso ou imagem discursiva, promover alguma ideologia, e não necessariamente algum fato pleno histórico. "Nenhuma memória pode ser um frasco sem exterior" (PECHEUX, 1999, p. 56), mas sempre seria "um espaço de desdobramentos, réplicas, polêmicas e contra discursos” (PECHEUX, 1999, p. 56).

Orlandi fala sobre o esquecimento no discurso - o da ordem da enunciação - que estabelece uma relação "natural" entre as palavras e as coisas, isto é, uma sensação de que o que dizemos só poderia ser dito daquela e não de outra forma. Trata-se de uma "ilusão referencial", uma crença na existência de uma relação direta entre o pensamento, a linguagem e o mundo:

Ele é parte da constituição dos sujeitos e dos sentidos. As ilusões não são "defeitos", são uma necessidade para que a linguagem funcione nos sujeitos e na produção de sentidos. Os sujeitos "esquecem" que já foi dito (...) para, ao se identificarem com o que dizem, se constituírem em sujeitos. É assim que (...) retomando palavras já existentes como se elas se originassem neles (...) sentidos e sujeitos estão em 
movimento, significando sempre de muitas e variadas maneiras. Sempre as mesmas, mas, ao mesmo tempo, sempre outras. (ORLANDI, 1999, p. 36)

Segundo Orlandi (1998, p. 206), os sentidos não se dão fora do sujeito, pois a produção de significados implica na produção dos sujeitos, "significa os sujeitos". Desse modo,

\begin{abstract}
Sujeito e sentidos se configuram ao mesmo tempo e é nisto que consistem os processos de identificação [...] identificamo-nos com certas idéias, com certos assuntos, porque temos a sensação de que eles 'batem' com algo que temos em nós. Ora este algo é o que chamamos de interdiscurso, o saber discursivo, a memória dos sentidos que foram se constituindo em nossa relação com a linguagem. Assim nos filiamos a redes de sentidos, nos identificamos com processos de significação e nos constituímos como posições de sujeitos relativas às formações, em face das quais os sentidos fazem sentidos (ORLANDI, 1998, p. 206).
\end{abstract}

Um sujeito que se constitui socialmente e por isso, é também alteridade, carrega em si o outro que transforma e é transformado por ele. Esse jogo identitário se configura, então, a partir do que o outro que diz o que e quem sou, como e por que sou. Tendo em vista essas questões, as identidades e subjetividades não podem ser compreendidas fora de um processo de produção simbólica e discursiva, considerando o caráter relacional, de processualidade, de perfomatividade, bem como os componentes sociais e ideológicos que as envolvem (SILVA; WOODWARD, 2007, p.50-55). De acordo com Woodward (2007, p. 55), subjetividade e identidade são processos atrelados à linguagem e ao social, são conceitos sobrepostos, mas que podem ser diferenciados da seguinte maneira:

Subjetividade sugere a compreensão que temos sobre nosso eu. O termo envolve os pensamentos e emoções conscientes e inconscientes que constituem nossa concepção sobre quem nós somos. Entretanto, nós vivemos nossa subjetividade em um contexto social no qual a linguagem e a cultura dão significado à experiência que temos de nós mesmos e no qual nós adotamos uma identidade [...] As posições que assumimos e com as quais nos identificamos constituem nossas identidades. (WOODWARD, 2007, p. 55)

Nas palavras de Smolka (2000, p. 31), “os indivíduos são afetados de diferentes modos, pelas variadas maneiras de produção nas quais eles participam [...] são profundamente afetados por signos e sentidos produzidos nas (e na história) das relações com outros". A constituição da subjetividade pressupõe um sujeito ativo, e principalmente interativo, que vai se construindo na e pelas relações sociais com o outro, com a cultura, a história e a sociedade.

Embora haja imposição, há também um processo de resistência, no qual o sujeito resiste e/ou reelabora as diversas formas de imposição do outro. Dessa maneira, "certos modos de apropriação, podem, no entanto, ocorrer, produzindo sentidos não esperados, não previstos, não predizíveis" (SMOLKA, 2000, p. 37). Para Chartier, a "construção das identidades sociais resultam sempre de uma relação de força entre as representações impostas pelos que detêm o poder de classificar e de nomear e a definição de aceitação ou de resistência, que cada comunidade produz de si mesma". (CHARTIER, 1991, p. 183).

\title{
3. Análise do discurso sobre o Brasil na mass mídia
}

Entre toda informação que circula na sociedade, redes sociais, mass mídia nacional e internacional, o discurso sobre Brasil segue seu trajeto constituindo efeitos de sentido e orientando determinadas práticas histórico-sociais. Esse discurso engloba regularidades e 
instabilidades, com todas suas contradições entre dito e não dito, concretiza-se em diversas acontecimentos em que os sentidos se efetivam.

O poder do discurso pode ser utilizado pela mídia como um instrumento de apoio dos sentidos, favoráveis para a materialidade histórica concreta, por exemplo, para favorecer ou para desfavorecer as ações armadas na opinião social, para gerar protestos sociais, ou para mover a sociedade de ajudar para os refugiados da guerra, ou justificar a recusa de ajuda para eles $^{2}$.

Voltando à questão das identidades no Brasil, o aparelho ideológico da mass mídia coloca os sujeitos que moram no Brasil no certo sentido da produção ideológica nos vários sentidos, entre eles podemos tomar como exemplo, o discurso sobre corrupção.

Figura 1 - Mass mídia - Discurso sobre corrupção

\section{Tolerância da sociedade faz corrupção ser grande, diz desembargador}

Adriano Brito da BBC Brasil em São Paulo

17 setembro 2015

1. [...] O evento, relata, teve uma votação para eleger os casos de corrupção "do momento" no mundo. "Foram três: o do primeiro-ministro da Malásia (US\$ 600 milhões foram descobertos em sua conta), o da Fifa e... o da Petrobras." [...]

2. Defensor da delação premiada e da alienação de bens, ele afirma ver, na sociedade, tolerância com a corrupção. "Sonegação não passa de corrupção", exemplifica.

3. [...] De Sanctis - O problema sempre existiu, obviamente. A corrupção existe em todo lugar. No país desenvolvido, os agentes corruptos usam de maneira indevida o sistema. Nos subdesenvolvidos, o sistema é fraco.

4. Em todo o Brasil, o sistema é fraco. É uma luta inglória para conseguir dar a sentença $[\ldots]$.

5. A nossa tolerância é que faz com que a corrupção seja grande. E não porque os corruptos estão lá, como se fosse algo dissociado da cultura em que estão inseridos.

6. [...] O Brasil tem que realmente passar a limpo, com seriedade. E não usando a legislação para benefício do crime organizado.

7. [...] O que me marcou é que o sistema está de tal forma ineficiente que faz com que certas pessoas que estão atuando conforme a lei virem heróis. Isso é péssimo. Não é a pessoa física que precisa ser valorizada. É preciso ter instituições fortes que sejam valorizadas.

Fonte: http://www.bbc.com/portuguese/noticias/2015/09/150917_entrevista_sanctis_ab Acesso em 22 de setembro de 2015.

\footnotetext{
${ }^{2}$ Estamos nos referindo aos refugiados da Síria, que foram aceitos, por exemplo, na Alemanha, com apoio social e recusados de entrar para alguns outros países da União Europeia, ambos os sentidos de "aceitar" ou "recusar" foram discutidos pela mídia. Fonte: BBC Brasil "Por que os refugiados querem ir à Alemanha?" de 08 set 2015 ; http://www.bbc.com/portuguese/noticias/2015/09/150908_europa_refugiados_hb; último acesso em 04 out 2015. "Europeus fazem manifestações pró e contra refugiados" de 12 set 2015; http://www.bbc.com/portuguese/videos_e_fotos/2015/09/150912_atos_europa_lk; último acesso em 04 out 2015.
} 
$\mathrm{O}$ artigo da BBC (fig.1) está falando em excesso sobre corrupção no Brasil, que seria o discurso principal do texto. Após de dividir esse artigo em partes, podemos apontar no discurso negativo marcante do artigo que indica que:

Figura 2 - Analisando o discurso no artigo "Tolerância da sociedade faz corrupção ser grande, diz desembargador"; da BBC Brasil em São Paulo datado de 17 setembro 2015Brasil seria um dos líderes em corrupção no mundo. (linha 1)

- O cidadão brasileiro está responsável/culpado por corrupção no pais. (linhas 2,5)

- O cidadão brasileiro tolera, sonega a corrupção. (linhas 2, 5)

- O cidadão brasileiro é corrupto. (linhas $1,2,3,5,7$ )

- A existência da corrupção é óbvia e eterna. (linha 3)

- Brasil é um pais subdesenvolvido. (linha 3)

- Todo Brasil tem sistema fraco. (linhas 7, 4)

- A corrupção está inserida na cultura brasileira. (linha 5)

- No Brasil usa-se legislação para o crime organizado. (linha 6)

- Brasil tem um sistema ineficiente e péssimo. (linha 7)

- Instituições no Brasil são fracoas e não têm valor. (linha 7)

Fonte: http://www.bbc.com/portuguese/noticias/2015/09/150917_entrevista_sanctis_ab Acesso em 22 de setembro de 2015.

Podemos supor, que após de ler o artigo referido acima (fig.1), o sujeito brasileiro, interpelado pela ideologia do discurso sobre a corrupção no seu país, supostamente pode começar a ver a corrupção como realidade evidente em qualquer acontecimento é pode evocar a esse discurso, identificando o Brasil como "fraco", "ineficiente", "subdesenvolvido" e assim por diante (fig. 2). Os artigos da mass mídia internacional e nacional, falando sobre corrupção no Brasil são consideravelmente numerosos ${ }^{3}$ para poder formar um discurso forte na sociedade brasileira, que pode afetar a construção da identidade do cidadão brasileiro. O discurso da mídia opera sob o efeito de uma aparente neutralidade, porém, considerando as relações de poder, mais especificamente, o poder da informação que chega ao público através da mídia, essa neutralidade não existe, ela é apenas um efeito produzido pelo funcionamento ideológico deste discurso. "A imagem perpassada pelo discurso não espelha a realidade" (BASTOS, 1993, p. 4), mas assume a função de espelho no qual o sujeito deveria buscar a sua imagem.

Dessa forma o discurso não representa o real, mas cria uma ideia do real, que o sujeito pode aceitar como real. Marcando uma posição bem delimitada, mídia efetua uma interpretação frente a memória discursiva. $\mathrm{O}$ discurso da mídia interpreta os fatos a partir dessa memória discursiva, estabelecendo certos sentidos para o Brasil, no caso, de um país corrupto, conivente com a sonegação e com a corrupção. $\mathrm{O}$ discurso da mídia afeta, constituindo o cidadão brasileiro (sujeito) neste lugar de interpretação.

O jornalismo tende a ser imparcial, porém, podemos ver um sentido instituído e defendido por um certo discurso do autor sobre certos valores supostamente importantes para o

\footnotetext{
${ }^{3}$ Utilizando o instrumento de busca dos artigos no site da agencia de notícias Thomson Reuters por período disponível de "ano passado", aparece 9750 resultados com busca de palavra-chave "Brazil", e 1340 resultados com palavra-chave "Corruption Brazil", que significa que 13,74 \% dos artigos sobre Brasil contem palavra "corrupção" Fonte: http://www.reuters.com/search/news?sortBy=relevance\&dateRange=pastYear\&blob=brazil (último acesso em 22 de setembro de 2015).
} 
público na construção da sua imagem e imagem de seu pais, tais como corrupção/honestidade, desenvolvimento/subdesenvolvimento do seu pais, sistema judiciário forte/fraco, eficiência/ineficiência do Estado.

Como já foi dito, o sujeito não está na origem dos seus dizeres ou opiniões porque não há o sentido original, os sentidos são históricos; logo, são sempre atravessados por outras vozes que os constituem - por exemplo, vozes da mass midia. Nesse contexto, podemos supor que a mídia desempenha um papel importante na construção de identidade do seu público, interferindo na maneira como o cidadão brasileiro (sujeito) vai enxergar os fatos.

Numa entrevista para GloboUniversidade ${ }^{4}$, Orlandi, refletindo sobre "o discurso sobre o brasileiro e do brasileiro sobre si mesmo", notou que "na interpretação, somos pegos pelas evidências já construídas, ao sabor das quais nos relacionamos com nossa realidade, imaginária".

Assim, como podemos notar no exemplo do artigo midiático do jornal BBC Brasil (fig.1), está se construído a realidade:

- da evidência da corrupção no Brasil: O problema sempre existiu, obviamente. A corrupção existe em todo lugar. (linha 3)

- da tolerância do brasileiro: utilização da palavra "nossa" em frase "a nossa tolerância" cria um efeito de que essa caraterística pertence ao todos os "nos" - brasileiros;

- da corrupção inserida na cultura;

- da culpa/responsabilidade do brasileiro por corrupção: A nossa tolerância é que faz com que a corrupção seja grande. E não porque os corruptos estão lá, como se fosse algo dissociado da cultura em que estão inseridos. (linha 5)

- da corrupção grande, chamado atenção do público para que a corrupção no Brasil é da importância mundial:

Os casos de corrupção "do momento" no mundo. "Foram três: o do primeiro-ministro da Malásia (US\$ 600 milhões foram descobertos em sua conta), o da Fifa e... o da Petrobras." (linha 1)

A nossa tolerância é que faz com que a corrupção seja grande (linha 5)

Na mesma entrevista, Orlandi, adiciona ainda, que "não é o que você diz, é como você diz que implica num sentido. As palavras escolhidas para uma mesma coisa, por sujeitos ou em situações diferentes, significam diferentemente umas das outras".

As palavras escolhidas pelo autor do artigo (fig.1) na descrição da situação com corrupção no Brasil são expressivas e de sentido abrangente, tais como "sempre existiu, obviamente", "todo o Brasil", "luta inglória", "nossa tolerância faz (...) corrupção (...) grande”, "dissociado na cultura”, "passar a limpo", "benefício do crime organizado", "ineficiente". As palavras escolhidas, de uma maneira, têm certa tendência de acusar o cidadão brasileiro e o Brasil por serem "subdesenvolvidos", "fracos", "corruptos" e "ineficientes".

\section{Considerações finais}

Considerando o poder da mídia sobre a sociedade, a mídia está se tornando um objeto privilegiado das investigações dos analistas do discurso. A mídia é um dos meios de comunicação que mais qualifica o seu público e desempenha um papel importante na vida social das pessoas. Tendo no seu arsenal os meios fortes de

\footnotetext{
4 "Eni Orlandi fala sobre análise do discurso e linguagem em entrevista", 28/02/2013, por Tatiana Fávaro, São Paulo. Fonte: http://redeglobo.globo.com/globouniversidade/noticia/2012/11/eni-orlandi-fala-sobre-analise-dodiscurso-e-linguagem-em-entrevista.html último acesso 02 de outubro de 2015.
} 
manipulação sobre pensamento e comportamento de muitas pessoas, a mídia exerce um grande poder no inconsciente do seu público, quase sempre imperceptível, mas sendo de um modo ativo.

Assim, este trabalho foi dirigido pelo anseio de mostrar que mesmo as grandes agências internacionais da mídia, tais como BBC, que é uma das maiores agências internacionais de notícias e multimídia do mundo, têm a tendência de fornecer as informações com a visão dos interesses políticos, comerciais ou sociais.

Além da análise comprobatória da presença de um certo discurso nos artigos midiáticos sobre o Brasil, levantamos a base teórica mostrando o efeito de tal discurso sobre sociedade brasileira, que seria um dos fatores que afetam a imagem do cidadão brasileiro sobre o seu país e sobre o si mesmo, em certa forma construindo, assim, a identidade do brasileiro.

\section{Referências}

BASTOS, M.H. COLLA, A. Retratando mestres: a idealização do professor na representação da docência. Porto Alegre: UFRGS, FACED, 1993.

BERNAYS, Edward. Propaganda. Disponível em: <http://www.historyisaweapon.com/defcon1/bernprop.html>. Acesso em: 02 out. 2015, 1928.

CHARTIER, Roger. O mundo como representação. São Paulo : In: Estudos Avançados. 5, n. 11, Jan./Abr, 1991.

GULHAUMOU, J. Considerações sobre a análise do discurso: um trajeto crítico em torno de Michel Pêcheux ao final dos anos 1970. In: BARONAS, R. L. e KOMESU, F. (orgs.) Homenagem a Michel Pêcheux. Campinas: Mercado de Letras, 2008.

ORLANDI, Eni Puccinelli. Análise de discurso: princípios \& procedimentos. Campinas: Pontes, 2013.

ORLANDI, Eni Puccinelli. Identidade lingüística escolar. In: Lingua(gem) e identidade. SIGNORINI, Inês (org.). Campinas, SP: Mercado de Letras, 1998.

PÊCHEUX, Michel. Análise automática do discurso. (AAD-69). In: GADET, F., e T. HAK. Por uma análise automática do discurso: uma introdução à obra de Michel Pêcheux. Campinas: Ed. Unicamp, 2001a.

PÊCHEUX, Michel. ORLANDI, E.P. Papel da memória. In: ACHARD, P. (Org.) Papel da memória. Campinas: Pontes, 1999.

PÊCHEUX, Michel. Analise Automatica do Discurso. Campinas: UNICAMP, 1997.

SILVA, Tomaz Tadeu (org.). HALL, Stuart. WOODWARD, Kathryn. Identidade e diferença: a perspectiva dos estudos culturais. Petropólis, RJ: Vozes, 2007.

SMOLKA, A.L.B. O (im)prórpio e o im(pertinente) na apropriação das práticas sociais. Caderno Cedes, ano XX, nº 50, abr/2000.

TASSO, Rossana Dutra. Uma desordem silenciada? O sujeito e a identidade em questão. Porto Alegre: UFRGS, 2005. 


\title{
Notas sobre a estética autoetnográfica no documentário ${ }^{1}$
}

\author{
Juliano José de Araújo (UNIR)
}

\section{Introdução}

Este artigo objetiva pensar quais são as implicações estéticas para o audiovisual de não-ficção, a partir da realização de documentários por comunidades indígenas. Para tanto, analisaremos documentários da série Cineastas indígenas, realizados no âmbito do projeto Vídeo nas Aldeias (VNA) ${ }^{2}$. Buscaremos identificar os procedimentos estilísticos utilizados nesses documentários, os quais acreditamos, a título de hipótese, caminhar rumo à configuração de uma estética autoetnográfica no audiovisual de não-ficção.

As produções audiovisuais de caráter etnográfico implicam, necessariamente, na ideia de uma alteridade, pois como nos lembra Pat Aufderheide (2011, p. 181), trata-se de "um olhar de fora sobre uma determinada cultura". Olhar, nesse caso, de um pesquisador, um antropólogo, um "homem branco", normalmente, com finalidades científicas. Os sujeitos, comunidades ou grupos sociais retratados por tais produções, entretanto, correm o risco de se tornarem meros exemplos e estatísticas para ilustrar e expor resultados, configurando uma modalidade chamada por Claudine de France (1998) de "filmes de exposição".

Essa visão "tradicional” do filme etnográfico começou a ser criticada nos anos 1950, em especial, nos trabalhos do antropólogo-cineasta Jean Rouch. A posição do interlocutor nativo, questões de epistemologia e ética estavam presentes em filmes como Os mestres loucos (1954-55), Jaguar (1954-67), Eu, um negro (1958-59), A pirâmide humana (1959-60), atingindo seu ápice em Crônica de um verão (1960), documentário co-dirigido com o sociólogo Edgar Morin.

Rouch pode ser considerado pioneiro e, sem dúvidas, estava muito à frente de outros antropólogos de sua geração, na medida em que para ele, segundo Paul Henley (2009, p. 321), o conhecimento deveria ser proveniente não da observação científica mas, ao contrário, de um

\footnotetext{
${ }^{1}$ Uma primeira versão deste texto foi apresentada no XVI Encontro da Sociedade Brasileira de Estudos de Cinema e Audiovisual (Socine) no Seminário Temático "Subjetividade, ensaio, apropriação, encenação: tendências do documentário", realizado no Centro Universitário Senac, em São Paulo, em 2012. A versão atual recebeu contribuições e foi ampliada.

${ }^{2}$ O projeto VNA foi criado em 1986 pelo indigenista e documentarista Vincent Carelli. Concebido inicialmente no âmbito do Centro de Trabalho Indigenista, uma associação criada por antropólogos e indigenistas no final da década de 1970, o projeto constituiu-se em uma ONG em 2000. Atua como uma escola de cinema para os povos indígenas através de oficinas de formação em audiovisual realizadas nas aldeias e na sede do projeto, em Olinda, no estado de Pernambuco. O projeto VNA desempenha também um papel fundamental como entidade responsável pela captação de recursos, produção e distribuição dos documentários. Hoje, o VNA possui um arquivo bruto de cerca de sete mil horas de material gravado, 87 filmes produzidos, inúmeros prêmios conquistados em festivais de cinema no Brasil e no exterior e, em particular, entendemos que sua maior conquista se expressa na formação de inúmeros cineastas indígenas de diferentes etnias brasileiras. Para um histórico do projeto VNA, ver Juliano José de Araújo (2015, p. 75-110), notadamente o capítulo "O audiovisual em comunidades indígenas: das experiências pioneiras ao projeto Vídeo nas Aldeias"
} 
processo de compromisso e engajamento entre cineasta e sujeitos, uma espécie de "ética do encontro" no processo de realização cinematográfico, conforme nos lembra Marcius Freire (2009).

É dessa forma que o antropólogo-cineasta começa a delinear os princípios de sua práxis cinematográfica, a qual denominaria de "antropologia compartilhada" e que consistia, basicamente, em fazer com que os sujeitos retratados nas produções audiovisuais, até então somente observados e vistos em uma perspectiva passiva, passassem a ter um papel ativo na construção da realidade cinematográfica, no filme e pelo filme, em um projeto de colaboração criativo e conjunto, seja por meio de um feedback das projeções, de sugestões de ideias e temas para realização de filmes, na participação no processo de realização etc.

Jean Rouch vai, gradativamente, incorporando métodos mais participativos em seu processo de realização cinematográfica. Embora não empregue o termo autoetnografia, entendemos que sua prática audiovisual já vislumbra a ideia de uma autoetnografia cinematográfica. Na conclusão de seu clássico artigo The camera and the man, ele afirma: " $\mathrm{E}$ amanhã? [...] Os sonhos de Vertov e Flaherty serão combinados em um 'cine-olho-ouvido' mecânico, o qual, como uma câmera participante, passará automaticamente para as mãos daqueles que estiveram, até agora, sempre na frente dela." (ROUCH, 2003, p. 98).

Um dos primeiros usos do termo autoetnografia na antropologia ocorreu, conforme nos explica Daniela Versiani (2005, p. 101), em 1975, quando Karl Heider chamou de autoetnografias "os relatos de sessenta crianças de uma escola elementar que responderam a um questionário sobre suas atividades habituais". Outro uso aparece, segundo a mesma autora, em 1979, em um artigo publicado por David Hayano, que lhe atribuiu o sentido de um "estudo feito por um antropólogo sobre seu próprio povo" (VERSIANI, 2005, p. 101). Um outro emprego interessante aparece em 1995, em um artigo de John Van Maanen, afirmando que em uma prática autoetnográfica as figuras do etnógrafo e do nativo reúnem-se em um mesmo indivíduo (VERSIANI, 2005, p. 102). Mas e no campo do audiovisual de não-ficção? Como a autoetnografia pode ser pensada no documentário?

Catherine Russel, no livro Experimental ethnography: the work of film in the age of video (1996), explica-nos que o termo "autoetnografia", na perspectiva adotada por ela nos estudos audiovisuais, foi introduzido por Mary Louise Pratt, que o entendia como um termo contrário, que surgiu em oposição à etnografia praticada pelos antropólogos. Se os textos etnográficos são meios pelos quais os Europeus representam para si os outros, normalmente sujeitos, comunidades e povos subjugados, os textos autoetnográficos são, segundo a autora, aqueles em que o outro constrói uma resposta para as representações do homem branco.

Entretanto, Russel (1996) modifica o conceito de Pratt, visto que entender que o mesmo, conforme apresentado, reafirma uma dualidade entre centro e periferia, entre um "eu" e um "outro". A autora reenquadra a autoetnografia como um autorrepresentação, na qual todo e qualquer sujeito é capaz de entrar nas formas textuais do discurso audiovisual, anunciando um rompimento total dos preceitos colonialistas. A autoetnografia trata-se, segundo Russel (1996, p. 276), de "um veículo e uma estratégia para desafiar formas impostas de identidade e explorar possibilidades discursivas de subjetividades não-autorizadas", como o caso dos povos indígenas.

Tendo em vista esse contexto teórico, discutiremos, a partir da metodologia da análise fílmica, na perspectiva proposta por Jacques Aumont e Michel Marie (2009), alguns procedimentos utilizados pelos cineastas indígenas, como a narração em primeira pessoa por meio de um uso diferenciado do comentário em voz-over, o emprego da encenação, o uso da 
imagem de arquivo etc. Os documentários, realizados no âmbito do projeto VNA e cujas sequências guiarão nossa análise, são: Shomõtsi (2001), de Valdete Ashaninka; Cheiro de pequi (2006), do Coletivo Kuikuro de Cinema; e Já me transformei em imagem (2008), de Zezinho Yube.

\section{Análise fílmica e procedimentos utilizados por cineastas indígenas}

O documentário Shomõtsi apresenta a crônica do cotidiano de Shomõtsi, tio do cineasta Valdete Ashaninka, que mora na fronteira do Brasil com o Peru e vai até a cidade receber sua aposentadoria. O filme emprega o comentário em voz-over de uma forma totalmente distinta da tradição documentária (nos quais a voz-over, também chamada de "voz de Deus" ou "voz do Saber", mantém uma relação hierárquica com os sujeitos do filme e com o espectador), visto que o cineasta Valdete adota uma narração que se inclui no filme por meio da primeira pessoa: "nossa mata", "Eu o escolhi”, "minha casa", "E eu vou mostrar", "Aqui termina o meu filme" etc.

Não queremos dizer que a voz-over de Valdete, diferente da voz-over tradicional, não explique, não tenha um conhecimento. A voz-over do documentário explica-nos que Shomõtsi é o nome de um pássaro, da mesma forma que é o nome do personagem do filme. Por outro lado, quando emprega a narração em primeira pessoa, a voz-over, enquanto suporte binário, que demarca nitidamente quem detém o conhecimento, uma separação entre quem "narra" e o que é "narrado", rompe com tal estrutura predominante em muitos filmes etnográficos.

Bill Nichols (1994, p. 67) explica-nos que o filme etnográfico, conforme realizado tradicionalmente pela antropologia, sempre trouxe em si a ideia de separação de culturas, que sustenta a realização do filme, entre um "nós" que filma, e um "eles" que são filmados. No documentário em análise, a situação é diferente: há laços fortes entre cineasta e personagem ou, em outros termos, sou "eu", o Ashaninka Valdete, que está filmando a vida de "minha" comunidade, de "meus" familiares e, por que não dizer, de "minha" própria história.

Ainda em relação à voz-over do documentário Shomõtsi, é pertinente observarmos que a mesma foi feita após a montagem do documentário, de forma improvisada, lembrando, por exemplo, o mesmo processo utilizado por Jean Rouch em Jaguar. "O filme foi montado sem a narração. Quando a Mari acabou, ela achou que estava faltando algo", afirma o coordenador do VNA, Vincent Carelli. "E eu dizia para o Valdete que ele precisava se colocar mais, e ele lá, travadão, sem saber o que dizer... A gente conhecia um filme inuit ${ }^{3}$, também um filme de oficina, que tem uma narração em decalagem com o que está sendo mostrado", comenta Mari Corrêa.

Após assistir o filme com o cineasta Valdete, os coordenadores esclarecem que gravaram a narração sem preparação alguma, a partir da própria improvisação do indígena, estimulada por questionamentos de Mari. "A narração começou a ser feita na ilha de edição. Ele com o microfone. Aí começamos a falar sobre o tio e eu perguntei: 'O que quer dizer Shomõtsi?' 'Bom, Shomõtsi é o nome de um passarinho...' Aí ele ligou para a aldeia para saber que passarinho era, que tipo de colibri...”, destaca Mari (CORRÊA, 2011, p. 17).

\footnotetext{
${ }^{3}$ Os coordenadores do VNA referem-se ao filme Mon village au Nunavik (1999), de Bobby Kenuajuak e Ame Papatsie.
} 
Em Cheiro de pequi, os cineastas indígenas, "ligando o passado ao presente", apresentam-nos "uma história de perigos e prazeres, de sexo e traição, onde homens e mulheres, beija-flores e jacarés constroem um mundo incomum" (VÍDEO NAS ALDEIAS, 2011). Os cineastas do Coletivo Kuikuro de Cinema, por meio de depoimentos e entrevistas com os mais velhos da aldeia, narram para o espectador a história mítica de Mariká e suas duas esposas, que o traíram com um Jacaré. Mariká, ao saber da traição, que lhe foi contada por uma cutia, flagra a infidelidade de suas esposas e mata o Jacaré com uma flecha invisível. As esposas enterram o Jacaré e colocam Mariká para fora de casa, que passa a viver na casa dos homens na aldeia. Após cinco dias, as duas mulheres vão até a sepultura de seu amante e veem que o Jacaré estava brotando, simbolizado por um pé de pequi.

Toda essa descrição é apresentada para o espectador por meio de uma encenação. Trata-se de uma estratégia retórica empregada pelos cineastas indígenas com a finalidade de, literalmente, dar "vida" à história apresentada pelos narradores. Procedimento antigo e corriqueiro na história do filme documentário, a encenação será usada em pelo menos outras três sequências do filme.

Todas as sequências de encenação de Cheiro de pequi correspondem, de acordo com a tipologia de Fernão Ramos (2008) para a encenação, à encenação-locação, uma vez que as tomadas são realizadas "na circunstância de mundo onde o sujeito que é filmado vive a vida" (RAMOS, 2008, p. 42). A encenação, no documentário em análise, é filmada na própria aldeia indígena, na comunidade dos Kuikuro, onde eles nasceram, cresceram e vivem até hoje. Assim, a partir dos depoimentos e entrevistas, que nos explicitam previamente a narrativa de Mariká e suas duas mulheres, a traição com o Jacaré, cuja morte deu origem ao pequi, os indígenas figuram para a câmera, dão vida a uma história do passado que se mantém viva na memória dos Kuikuro.

Acreditamos que é importante apontar também que o uso da encenação em Cheiro de pequi permite pensarmos nos procedimentos de auto-mise en scène e fabulação (FRANCE, 1998; COMOLLI, 2008), na forma como os indígenas, ao interpretarem personagens míticos de suas tradições, inventam a si mesmos durante as encenações, abandonando totalmente o ideário realista que marcou, historicamente, os filmes etnográficos.

Já me transformei em imagem traz, por sua vez, a partir do ponto de vista da comunidade indígena, a história da etnia Huni Kui, do Acre, a qual seria dividida em cinco tempos, a saber: o Tempo das Malocas (antes do contato dos indígenas com os brancos), o Tempo das Correrias (frentes de exploração da borracha/duas últimas décadas do século XIX/exploração de mão de obra nordestina), o Tempo do Cativeiro (a partir de 1910 os patrões seringalistas recrutam mão de obra indígena com a queda do preço da borracha), o Tempo dos Direitos (a partir dos anos 1970 com a demarcação das terras indígenas) e o Tempo Presente.

O cineasta indígena Zezinho Yube constrói a narrativa do documentário a partir de depoimentos, entrevistas e imagens de arquivo. O documentário traz trechos dos seguintes filmes: No país das Amazonas, dirigido por Silvino Santos, em 1921; Fishing expedition and ensuing festival, de 1951, cujo diretor foi Harald Schultz; Fruto da aliança dos povos da floresta, de 1987, dirigido por Siá Kaxinawá; Borracha para a Vitória, com o diretor Wolney Oliveira, de 2004 e; Fordlândia, o sonho amazônico, de Henri Ford, produzido em 2001, sob a direção de Alfeu França. Há também inúmeras fotografias do acervo de Harald Schultz, do Serviço de Proteção aos Índios, tiradas no contexto da Comissão Rondon. 
Nessa perspectiva, Já me transformei em imagem nos proporciona uma reflexão sobre a "história oficial" do Brasil, mostra-nos que as áreas indígenas foram invadidas pelos seringueiros, que muitos indígenas foram capturados, obrigados a trabalhar em um regime de semiescravidão, ou mesmo mortos, além de terem sido "marcados", como se faz com o gado, com as iniciais dos nomes de seus patrões. Todo o material de arquivo empregado foi, portanto, ressignificado, na medida em que as imagens foram feitas, sobretudo as que pertencem ao acervo do Serviço de Proteção aos Índios, originalmente, para serem exibidas em um contexto de progresso, como símbolo do suposto desenvolvimento do país, da forma como o homem branco levava a "civilização" ao indígena "selvagem".

Zezinho Yube emprega as imagens de arquivo na perspectiva de narrar a história dos Huni Kui e faz, como nos sugere Georges Didi-Huberman, uma espécie de montagem, pois somadas aos depoimentos, entrevistas e à narração em voz-over, o material de arquivo adquire um novo sentido, totalmente diferente daquele no qual foi inicialmente apresentado. As imagens de arquivo, por meio da montagem, mostram-nos, como afirma Didi-Huberman (2009, p. 78), "que as coisas talvez não sejam o que são e que cabe a nós vê-las de outra forma, segundo a disposição proposta pela 'imagem crítica' obtida pela montagem”.

\section{Considerações finais}

Para concluir, gostaríamos de retomar o questionamento que, inicialmente, levantamos: quais são as implicações estéticas para o audiovisual de não-ficção a partir da realização de documentários por comunidades indígenas? Procuramos, a partir da análise de alguns documentários realizados por cineastas indígenas, identificar procedimentos estilísticos que nos permitissem pensar em uma estética autoetnográfica no campo do documentário.

Como principais características dessas produções audiovisuais, na perspectiva sugerida por Russel (1996), e de forma sistematizada a partir da análise apresentada, indicamos: a narração em voz-over em primeira pessoa; o olhar fixo do sujeito, que pode encarar o espectador no eixo "olhos nos olhos"; a imagem corporal do sujeito, que pode realizar verdadeiras performances, em uma espécie de "encenação da subjetividade"; o papel da justaposição, ironia, arranjos e rearranjos possibilitados pela montagem, o que também permitenos pensar nas imagens de arquivo; o uso da encenação, embaralhando livremente as fronteiras entre ficção e documentário.

É importante também considerar, embora não tenha sido o foco de nossa análise, a presença e valorização dos tempos fracos e mortos, a abertura ao improviso e a presença de impurezas nos documentários, como também a ideia de seus roteiros serem baseados na tradição oral, questão tão cara a Jean Rouch. Nas produções audiovisuais analisadas, o cineasta, no caso, indígena, filma sua própria comunidade, questão que repercute sobremaneira na relação estabelecida entre cineasta e sujeitos filmados. Por fim, visto que o outro, agora, trata-se de um "outro familiar", esses filmes podem lidar com processos difíceis que envolvem recordações e lembranças, uma imbricação entre história e memória, onde a memória "individual" surge justaposta à memória "coletiva". 


\section{Referências}

ARAÚJO, Juliano José de. Cineastas indígenas, documentário e autoetnografia: um estudo do projeto Vídeo nas Aldeias. Tese (Doutorado) - Universidade Estadual de Campinas, 2015.

AUFDERHEIDE, Pat. "Vendo o mundo do outro, você olha para o seu". In: ARAÚJO, Ana Carvalho Ziller (Org.). Vídeo nas Aldeias 25 anos. Olinda: Vídeo nas Aldeias, 2011.

AUMONT, Jacques e MARIE, Michel. A análise do filme. Lisboa: Edições Texto \& Grafia, 2009.

COMOLLI, Jean-Louis Ver e poder: a inocência perdida. Belo Horizonte: Editora UFMG, 2008.

CORRÊA, Mari. "Conversa a cinco". $\quad$ Disponível em http://www.videonasaldeias.org.br/2009/biblioteca.php?c=15. Acesso em 29/06/2011.

DIDI-HUBERMAN, George. Quand les images prennent position. Paris: Les Éditions de Minuit: 2009.

FRANCE, Claudine. Cinema e antropologia. Campinas: Editora da Unicamp, 1998.

FREIRE, Marcius. "Jean Rouch e a ética do encontro". In: Devires. Belo Horizonte, vol. 6., n. 2, jan./jun. 2009.

HENLEY, Paul. The adventure of the real: Jean Rouch and the craft of ethnographic cinema. Chicago: The University of Chicago Press, 2009.

NICHOLS, Bill. Blurred boundaries. Indianapolis: Indiana University Press, 1994.

RAMOS, Fernão. Mas afinal... o que é mesmo documentário? São Paulo: Senac, 2008.

ROUCH, Jean. "The camera and the man". In: HOCKINGS, Paul (Org.). Principles of visual anthropology. Mouton de Gruyter: Berlim, Nova Iorque, 2003.

RUSSEL, Catherine. Experimental ethnography: the work of film in the age of video. Londres: Duke University Press, 1999.

VERSIANI, Daniela. Autoetnografias: conceitos alternativos em construção. Rio de Janeiro: 7Letras, 2005.

VÍDEO NAS ALDEIAS. 2011. Acesso em: 25/06/2011, disponível em http://www.videonasaldeias.org.br. 


\section{SOBRE OS AUTORES E AUTORAS}

ÉLCIO ALOISIO FRAGOSO: Professor do Departamento de Línguas Vernáculas, dos Mestrados em Letras e em História e Estudos Culturais- UNIR. Email: elciofragoso@unir.br. Graduado em Letras e Pedagogia, especialista em Língua Portuguesa, mestrado e doutorado em Linguística pela Unicamp.

ELIZABETE MATIA DE SIQUEIRA: Licenciada em Economia Doméstica pela Faculdade de Ciências Humanas de Francisco Beltrão. Especialista em Gestão Escolar e Mestranda em História e Estudos Culturais pela Universidade Federal de Rondônia. Professora da Rede Estadual de Ensino de Rondônia. Gerente de Gestão Escolar na Secretaria de Estado da Educação de Rondônia.

FÁBIO TEIXEIRA LIMA: Graduado em Licenciatura Plena em História - UNINORTE. Especialização em História e Historiografia da Amazônia - UFAM Especialista em Educação para a Terceira Idade - AVM. Professor de História do Instituto Federal de Educação, Ciência e Tecnologia do Amazonas-IFAM. E-mail: fabiolima18.2009@ hotmail.com.

JOSÉ LUCAS PEDREIRA BUENO: Professor-pesquisador da área de Formação de professores; Educação e comunicação; Tecnologia educacional; Tecnologias aplicadas à educação; Educação à distância; Letramento e inclusão digital e Cultura, mídia e educação. Licenciado em Letras (Português e Inglês) e Especialista em Língua Portuguesa pela UEMG. Graduado em Gestão da Tecnologia da Informação pela Unisul. Mestre e Doutor em Engenharia de Produção pela UFSC. Email: lucas@unir.br.

JOEL BALDUINO DA SILVA JUNIOR: Licenciado em história pela UNIR- Universidade de Federal de Rondônia. É Professor da rede pública Estadual e Municipal de Porto Velho. Mestrando do Mestrado em História e Estudos Culturais- UNIR. Especialista em História Regional de Rondônia pela UNIRON. Email: joelbalduino@hotmail.com. 
JOSÉ WILLIANS SIMPLICIO DA SILVA: Graduado em História pela Universidade do Estado do Rio Grande do Norte - UERN. Mestrando em História e Estudos Culturais pela Universidade Federal de Rondônia - UNIR. E-mail: williansconselho@yahoo.com.br

JULIANO JOSÉ DE ARAÚJO: Doutor em Multimeios pela Universidade Estadual de Campinas, tendo realizado estágio de doutorado na Université Paris Ouest Nanterre La Défense. É mestre em Comunicação pela Universidade Estadual Paulista, onde se graduou em Comunicação Social/Jornalismo. É professor adjunto do Departamento de Comunicação Social/Jornalismo do Campus de Vilhena da Universidade Federal de Rondônia. É líder do Grupo de Pesquisa e Extensão em Audiovisual. E-mail: araujojuliano@gmail.com

JURACY MACHADO PACÍFICO: Doutora em Educação Escolar pela Universidade Estadual Paulista-UNESP, Mestre em Psicologia Escolar pela Universidade de São Paulo-USP e graduada em Pedagogia pela Fundação Universidade Federal de Rondônia. Atualmente é Professora Adjunta II da Fundação Universidade Federal de Rondônia, atuando no Curso de Licenciatura em Pedagogia, no Programa de Pós-Graduação em Psicologia, Mestrado Acadêmico (MAPSI) e no Programa de Pós-Graduação em Educação Escolar, Mestrado Profissional (MEPE), do qual é também coordenadora adjunta.

LILIAN MARIA MOSER: Doutora em Ciências Sócio Ambiental pela Universidade Federal do Pará-UFPA. Professora titular do Mestrado em História e Estudos Culturais da Universidade Federal de Rondônia-UNIR. E-mail: lilian.msr@gmail.com.

LIUBOV TARASOVA: Aluna do Mestrado em Letras, UNIR, Porto Velho, RO. Graduada na Rússia, em Letras/Inglês/Russo. Atua em pesquisas da diversidade cultural, pesquisas sobre a Rússia. Membro do GELLSO. Email: lyubatarasova@gmail.com.

MARIA APARECIDA DA SILVA: Graduada em História pela Universidade Federal da Amazônia, Especialista e História Regional (Rondônia/Amazônia) pela FAP - Faculdade de Pimenta Bueno - Rondônia e Mestranda em História e Estudos Culturais pela Universidade Federal de Rondônia. Professora da SEDUC/RO e Professora do Curso de Especialização em História da Amazônia com ênfase em História de Rondônia, da FAROL - Faculdade de Rolim de Moura . Tem experiência no ensino superior com a atuação como Professora Substituta no Curso de História Departamento de História Campus de Rolim de Moura - RO. Email: cidaselhorst@yahoo.com.br 
MAURO ANTÔNIO DOS SANTOS: Mestrando do curso de Pós Graduação em História e estudos Culturais do Núcleo de Ciências Humanas da Universidade Federal de Rondônia UNIR. Email: mauro_antonios@hotmail.com.

MIGUEL NENEVÉ: Professor do DLE e dos Mestrados em Letras e Estudos Literários UNIR. Email: nenevemi@gmail.com. Pesquisador CNPq nivel 2. Graduado em Letras pela UNISUL e em Estudos Sociais pela Fundação Educacional da Região de Jaraguá do Sul. Mestrado em Letras pela Universidade Federal da Paraíba e doutorado em Letras pela Universidade Federal de Santa Catarina. Tem pós-doutorado na York University, Toronto Canada e na University of Guyana. É Líder do grupo de pesquisa credenciado pelo CNPq Literatura, educação e cultura: caminhos da alteridade.

ODETE BURGEILE: Professora do Departamento de Línguas Estrangeiras, dos Mestrados em Letras e em História e Estudos Culturais- UNIR. Email: odetebur@gmail.com. Possui graduação em Letras (Inglês e Português) e Farmácia-bioquímica pela Universidade Estadual de Maringá-UEM. Especialista em Literatura Brasileira pela UEM. Mestrado em Letras pela UFPR e doutorado europeu pela UVIGO em Filologia Inglesa. É líder do grupo de pesquisa credenciado pelo CNPq - GELLSO.

RAIMUNDA ADRIANA MAIA COSTA: Mestranda em Educação, vinculada à Linha de Pesquisa de História, Política e Gestão Educacional na Amazônia - PPGE/UFOPA. Membro dos Grupos de Pesquisa: Histedbr, Oficiber e Práxis. E-mail: dricamaia30@gmail.co.

TÂNIA SUELY AZEVEDO BRASILEIRO: Doutora em Educação. Pós-doutora em Psicologia. Coordenadora do Programa de Pós-Graduação em Educação - PPGE/UFOPA. Líder do Grupo de Pesquisa Práxis e membro dos Grupos Histedbr e Oficiber. Email: brasileirotania@gmail.com.

WASHINGTON HELENO CAVALCANTE: Mestrando em História e Estudos Culturais pelo PMHEC da Universidade Federal de Rondônia (UNIR). Email: washelcav@ bol.com.br.

\section{Vanessa Aparecida Alves de Lima}

Possui graduação em psicologia (1993) e licenciatura em Geografia (1991) pela Universidade Federal de Rondônia (UNIR), mestrado (2000) e doutorado (2005) em Psicologia pelo Instituto de Psicologia da USP. Professora Associada da Universidade Federal de Rondônia (UNIR) - 
Departamento de Psicologia desde 2004. Atualmente à disposição da Universidade Federal de Santa Catarina - UFSC. Foi docente do Mestrado em Psicologia da UNIR (2009/2012). Também tem experiência como Professora de Ensino Fundamental, Médio e Educação de Jovens e Adultos e nas disciplinas de Psicologia Aplicada em Faculdades privadas do Estado de Rondônia e Cursos de Pós-Graduação Stricto-Sensu. 


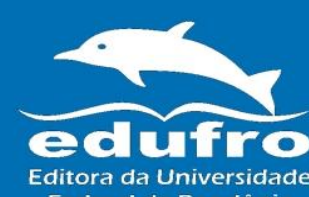

Editora da Universidade

Federal de Rondónia 